\title{
RENDIMENTO E VIABILIDADE ECONÔMICA DAS CULTURAS DE MILHO, SOJA E FEIJÃO SOB DIFERENTES SISTEMAS DE MANEJO DE SOLO, APÓS OITO ANOS DE PLANTIO DIRETO
}

\author{
CRISTINA MARIA RIBEIRO \\ Engenheira Agrônoma
}

Orientador: Prof. Dr. ANTÔNIO LUIZ FANCELLI

\begin{abstract}
Dissertação apresentada à Escola Superior de Agricultura "Luiz de Queiroz", Universidade de São Paulo, para obtenção do título de Mestre em Agronomia, Área de Concentração: Fitotecnia.
\end{abstract}

PIRACICABA

Estado de São Paulo - Brasil

Fevereiro - 2000 


\title{
Dados Internacionais de Catalogação na Publicação (CIP)
} DIVISÃO DE BIBLIOTECA E DOCUMENTAÇÃO - Campus "Luiz de Queiroz"/USP

\author{
Ribeiro, Cristina Maria \\ Rendimento e viabilidade econômica das culturas de milho, soja e feijāo sob \\ diferentes sistemas de manejo de solo, após oito anos de plantio direto / Cristina \\ Maria Ribeiro. - - Piracicaba, 2000. \\ $93 \mathrm{p}$. \\ Dissertação (mestrado) - - Escola Superior de Agricultura Luiz de Queiroz, 2000. \\ Bibliografia.
}

1. Aspecto econômico 2. Feijão 3. Manejo de solo 4. Milho 5. Plantio direto 6. Rendimento 7. Soja I. Título

CDD 633.15

"Permitida a cópia total ou parcial deste documento, desde que citada a fonte - 0 autor" 
A meus pais,

Maria Aparecida Mendonça Ribeiro e Eloi Ribeiro, por terem sido exemplo de dedicação e vontade, mesmo em momentos dificeis.

A meus irmãos,

André Luiz Ribeiro, Adriana Ribeiro e Beatriz Mendonça Ribeiro pelos maravilhosos momentos compartilhados.

A meu sobrinho,

Gustavo Ribeiro Piovezzana, pelas alegrias e amor renovadores.

Dedico.

A Márcia Morelli, por me fazer acreditar no tempo.

Ofereço 


\section{AGRADECIMENTOS}

Ao Prof. Dr. Antônio Luiz Fancelli, pelos conhecimentos transmitidos durante todos estes anos de convivência;

Ao Conselho Nacional de Desenvolvimento Científico e Tecnológico (CNPq) pela Bolsa de Estudos concedida;

Ao Prof. Dr. Gil Miguel de Sousa Câmara pela amizade, incentivo e apoio constantes;

Ao Prof. Dr. Durval Dourado Neto (pelo incentivo) e aos colegas de curso Marcela dos Santos Müller e Marcelo Hissnauer Miguel, pelas valiosas sugestões e amizade;

Ao produtor Ricardo de Castro Merola, proprietário da Fazenda Três Irmãos, por ceder infraestrutura física e funcionários necessários a condução do experimento;

A pesquisadora da EMBRAPA Lídia Pacheco Yokoyama, pelo auxílio nos estudos econômicos;

Aos técnicos do CNPAF Floriano, Zé Macio e Tinoco, pelo apoio técnico e companheirismo;

Ao demais funcionários da EMBRAPA e da Fazenda Três Irmãos que contribuiram com dados e análises pertinentes;

Aos funcionários da ESALQ, Adriana Gimenes, Celestino Alves Ferreira, Silvia Borghesi e Maria Aparecida Soledade, pela colaboração;

Aos companheiros de curso, João Kluthcouski, Luiz Antônio Ferraro Jr., Fernando Flávio Bernardes, Mônica Cagnin Martins, Patrícia Mattiazzi, Rodrigo Guerzoni e Clóvis Peixoto pela troca de informações e amizade;

A todos que compartilharam desta experiência comigo. 
SUMÁRIO

Pag.

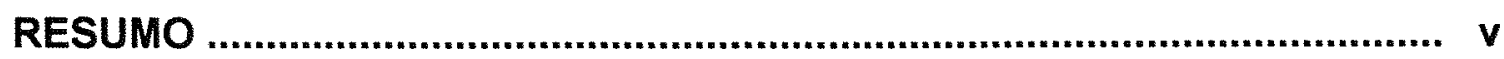

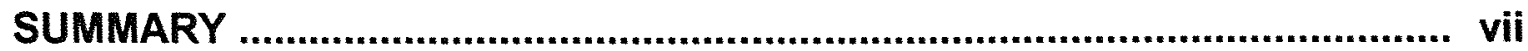

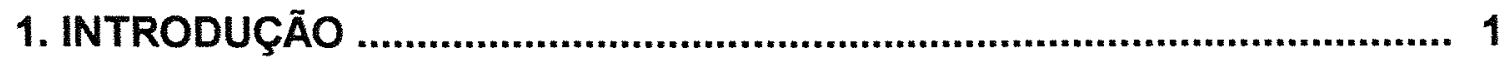

2. REVISÃO DE LITERATURA …........................................................ 4

2.1 Cerrado: caracteristicas regionais ..................................................... 4

2.2 Patamar de produtividade ................................................................. 6

2.3 Sistema de semeadura convencional .................................................. 8

2.3.1 Implicações da exploração inadequada ............................................. 8

2.4 Sistema de plantio direto....................................................................... 11

2.4.1 Plantio direto na região dos cerrados: problemas para sua

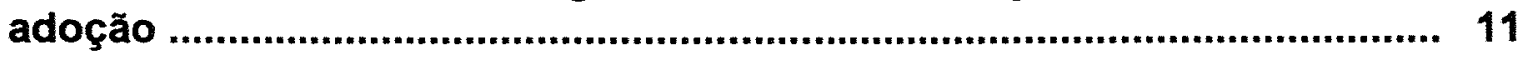

2.4.2 Efeito nos atributos químicos e físicos do solo ............................ 12

2.5 Rendimento em plantio direto e convencional ................................... 19

2.6 Rentabilidade em plantio direto e convencional .................................. 23

3. MATERIAL E MÉTODOS .................................................................... 31

3.1 Caracterização da área experimental ...................................................... 31

3.2 Condução dos experimentos .......................................................... 32

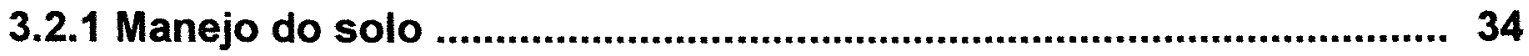

3.2.1.1 Aração profunda .............................................................................. 34

3.2.1.2 Escarificação ......................................................................... 34

3.2.1.3 Gradeação............................................................................................ 35

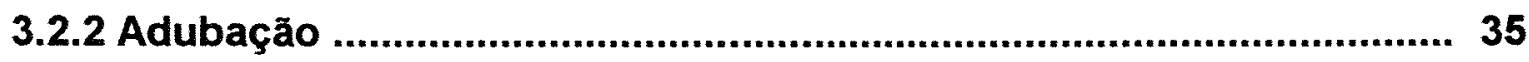

3.2.3 Implantação das culturas estudadas .............................................. 37

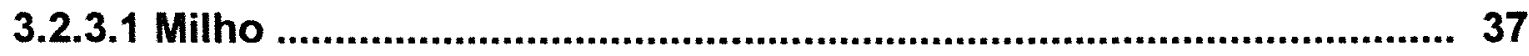

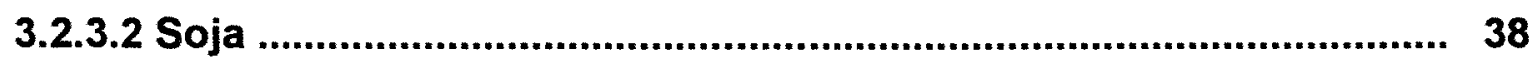

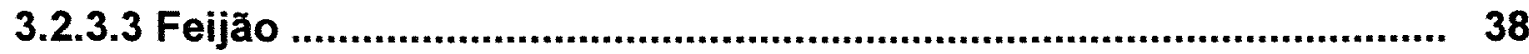

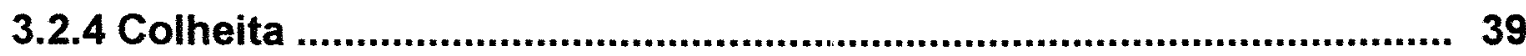


3.3 Delineamento experimental ................................................................... 39

3.4 Determinações gerais .............................................................................. 40

3.4.1 Fertilidade do solo ................................................................................. 40

3.4.2 Parâmetros físicos do solo ............................................................... 41

3.4.3 Custos de produção .............................................................................. 42

4. RESULTADOS E DISCUSSÃO …....................................................... 44

4.1 Fertilidade do solo ............................................................................ 44

4.2 Análise física do solo ........................................................................... 51

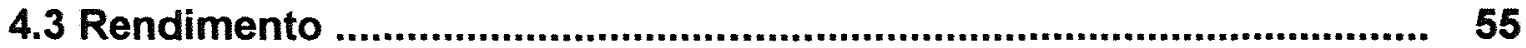

4.4 Análise econômica ............................................................................ 58

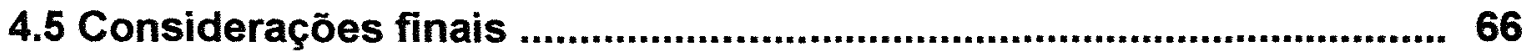

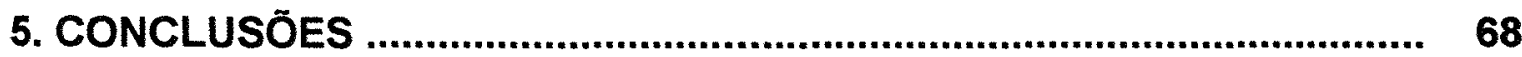

REFERÊNCIAS BIBLIOGRÁFICAS ...................................................69

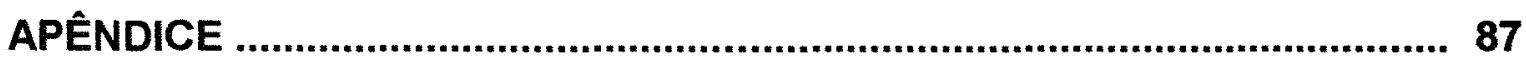




\title{
RENDIMENTO E VIABILIDADE ECONÔMICA DAS CULTURAS DE MILHO, SOJA E FEIJÃO SOB DIFERENTES SISTEMAS DE MANEJO DE SOLO, APÓS OITO ANOS DE PLANTIO DIRETO
}

\author{
Autora: Cristina Maria Ribeiro \\ Orientador: Prof. Dr. Antônio Luiz Fancelli
}

\section{RESUMO}

Com o objetivo de avaliar o efeito de diferentes sistemas de manejo de solo no rendimento e na receita líquida das culturas de milho, soja e feijão, após oito anos de plantio direto, foi realizado um trabalho de campo na Fazenda Três Irmãos, localizada no municipio de Santa Helena, Goiás (LS $17^{\circ} 48^{\prime} 49^{\prime \prime}$, LW $50^{\circ} 35^{\prime} 49^{\prime \prime}$ e 615 m de altitude).

Para tanto empregou-se 0 delineamento experimental de blocos completos casualisados, em faixas, com 4 repetições. Os tratamentos estudados foram constituídos do sistema de plantio direto (PD), grade aradora (GA), escarificação (ES) e aração profunda (AP), submetidos a dois tipos de adubação, $\mathrm{T}=$ ausência de fornecimento de $\mathrm{P}$ e $\mathrm{K}$ e $\mathrm{Eg}=$ fornecimento de $\mathrm{P}$ e $\mathrm{K}$ fundamentado na exportação desses nutrientes pela colheita dos grãos.

A análise dos resultados permitiu concluir que: 1) a consolidação de camadas de compactação relacionada ao uso contínuo de plantio direto em solo argiloso afeta o rendimento das culturas, principalmente de milho e feijão; 2) o incremento no rendimento das culturas de milho e soja, proporcionado pela 
destruição da camada de compactação do solo, não se reverte em aumento da receita líquida das culturas mencionadas, devido à elevação dos custos de produção; 3) a cultura de feijão implantada em área mantida sob plantio direto por longo período, responde ao emprego da aração, resultando no aumento do rendimento e da receita líquida auferida pela cultura, principalmente em terrenos de elevada incidência de Fusarium sp. e Rhizoctonia solani pv. Phaseoli. e 4) os benefícios inerentes ao plantio direto são extremamente dependentes dos cuidados dispensados na etapa de implantação desse sistema. 


\section{YIELD AND ECONOMIC VIABILITY OF MAIZE, SOYBEAN AND COMMOM BEAN, UNDER DIFFERENT SOIL MANAGEMENT SYSTEMS, AFTER EIGHT YEARS OF CONTINUOUS NO-TILLAGE}

Author: Cristina Maria Ribeiro

Adviser: Prof. Dr. Antônio Luiz Fancelli

\section{SUMMARY}

With the purpose of evaluating the effect of differents soil management systems on crop yield and net return of corn, soybean and common bean crops after eight years of continuous no-tillage, a field experiment was carried out Três Irmãos Farm, in Santa Helena county, Goiás State, Brazil (Latitude $17^{\circ} 48^{\prime} 49^{\prime \prime}$ South, Longitude $50^{\circ} 35^{\prime} 49^{\prime \prime}$ West and altitude $615 \mathrm{~m}$ ).

The statistical model obeyed a completly randomized blocks design, using strip plots and four replicates. The treatments adopted were no-tillage system, heavy harrowing, chiseling and deep moldboeard plowing, submitted to two fertilizations types, no-phosphorus and no-potassium, and supply of phosphorus and potassium based on reposition of exported nutrients by grains.

The results indicated that 1) there was layer compaction consolidation, due continuous no-tillage on clay soil, affecting crop yield (corn and common bean, mainly); 2) the increase of corn and soybean yields, obtained by compaction layer destruction, did not result in higher net return because it had high operational costs; 3 ) Common bean kept in no-tillage system for long 
periods had significant response to deep moldboard plowing increasing yield and net return (it was verified in areas with high populations of Fusarium sp. and Rhizoctonia solani pv. phaseoli, mainly); 4) The benefits related to no-tillage system are extremely dependent of the implantation phase. 


\section{INTRODUÇÃO}

A exploração agrícola da região dos Cerrados é bastante recente, tendo se intensificado à partir da década de 80 , quando suas terras já apresentavam mais de 24 milhões de hectares ocupadas com culturas anuais e semi-perenes.

O Cerrado se estende de 5 a $20^{\circ}$ de latitude Sul e de 45 a $60^{\circ}$ de longitude Oeste, perfazendo 204 milhões de hectares (Assad, 1996). Desta vasta área, atualmente, cerca de $30 \%$ está ocupada por pastagens plantadas e culturas de grãos; sendo 75 milhões de hectares com pastagens naturais, 42 milhões de hectares com pastagens formadas, destas, 34 milhões são degradadas ou estão em processo de degradação, e 13 milhões de hectares com culturas anuais onde $50 \%$ da área destinada à produção de grãos apresenta o mesmo problema das áreas com pastagens (Yokoyama et al., 1995).

Porém, esta exploração tem sido inadequada, ocasionando degradação ambiental, com depauperamento dos solos e, conseqüente, redução do rendimento das culturas. Aliado à isto, fatores como a baixa fertilidade e acidez dos solos, bem como a ocorrência de veranicos também têm concorrido para o baixo rendimento das culturas exploradas nesta região.

Contudo, a maior parte das terras ocupadas são aptas à exploração agropastoril, com o agravante de estarem sendo degradadas com a justificativa da necessidade de se maximizar o rendimento agropecuário.

Esse empobrecimento biológico é ainda caracterizado pela extinção de espécies animais e vegetais, pela perda de capacidade produtiva dos vários 
ecossistemas existentes, alteração dos ciclos biogeoquímicos, aquecimento global e proliferação de espécies exóticas (Klink, 1996).

Nessa região, o manejo do solo e fatores climáticos (principalmente precipitação pluvial) são decisivos para a sustentabilidade da prática agrícola, principalmente pelo fato do solo apresentar baixa fertilidade e se tornar fisicamente inapto após a derrubada da vegetação natural e posterior preparo para plantio.

Com o uso excessivo da mecanização ocorre compactação do subsolo e a estrutura da superfície é desfeita com o revolvimento, ocasionando grandes perdas de solo e, conseqüentemente, de fertilidade, pela erosão hídrica e eólica.

Assim, os riscos para a atividade agrícola nesta região passam a ser maiores que aqueles representados pelas oscilações do clima e mercado, pois a erosão, perda de fertilidade e compactação, acabam por agregar custos à produção agrícola relativa ao do frágil ecossistema em questão.

Considerando-se, ainda, que a erosão não só provoca a perda de nutrientes, mas também concorre para o transporte de partículas físicas de solo, redução da capacidade de infiltração e armazenamento de água, além de assorear e poluir aqüiferos, pode-se concluir que os custos sociais, energéticos e econômicos são de difícil contabilização.

Desse modo, tecnologias que contribuam para a minimização da erosão e o depauperamento dos solos e para imprimir menores riscos à agricultura devem ser amplamente pesquisadas e inseridas no processo produtivo. Somando-se, ainda, à crescente necessidade de se maximizar o uso dos recursos de produção disponíveis, o conhecimento agronômico tem sido instigado a desenvolver alternativas tecnológicas de baixa utilização de insumos, em se tratando de atividades agropecuárias, a fim de se alcançar a sustentabilidade agrícola. Assim, sistemas apropriados de produção, cultivo conservacionista, uso correto e eficiente de insumos, maximização dos 
processos biológicos, entre outros, merecem especial destaque (Siqueira \& Moreira, 1996).

Dentro deste contexto, a adoção do sistema plantio direto, em solos de Cerrado poderá resultar na melhoria e ou na manutenção de sua fertilidade, bem como de suas propriedades fisicas, de seus teores de matéria orgânica e de suas propriedades biológicas.

Todavia, os resultados de pesquisa e experiências de produtores da região sul do país não podem ser aplicados diretamente na região tropical (Cerrados), necessitando-se de adaptação e geração de informações locais, principalmente no que concerne ao tipo e manejo da cobertura do solo, de plantas daninhas e pragas, principalmente.

O plantio direto exige alta tecnificação e qualificação do produtor e, portanto, estudos de viabilidade econômica são imprescindiveis para o sucesso do empreendimento agrícola, podendo levar ao fracasso aquele que não conseguir tornar o processo produtivo, estável e previsivel sob este sistema.

Este trabalho apresentou como objetivo principal a avaliação dos efeitos dos diferentes sistemas de manejo do solo, sob diferentes niveis de adubação, no rendimento das culturas de milho, soja e feijão e nas propriedades químicas e físicas de um solo cultivado há oito anos sob o sistema de plantio direto, incluindo a determinação da viabilidade econômica dos sistemas estudados. 


\section{REVISÃO DE LITERATURA}

\subsection{Cerrado: caracteristicas regionais}

A região dos Cerrados ocupa 2 milhões de $\mathrm{km}^{2}$ ou cerca de $23 \%$ do território nacional, estendendo-se principalmente pela região Centro-Oeste e atingindo ainda parte das regiões Norte, Nordeste e Sudeste, principalmente os Estados de Minas Gerais, Goiás, Mato Grosso, Mato Grosso do Sul, Bahia, Maranhão e Piauí (Cabral, 1980).

O clima da região é bastante heterogêneo devido a grande extensão territorial, entretanto, a maior parte é classificada, segundo W. Köeppen, como clima $A_{w}$-quente e úmido (clima tropical de savana) com uma longa estação seca, com duração de cinco a seis meses por ano (Lopes, 1983).

A temperatura média anual oscila entre 20 (ao sul da região) e $26^{\circ} \mathrm{C}$ (ao norte) e as diferenças entre as temperaturas máximas e mínimas oscilam entre 4 e $5^{\circ} \mathrm{C}$, reduzindo progressivamente para o norte (região Amazônica). A pluviosidade anual varia de $750-800 \mathrm{~mm}$ na parte mais seca desta região (lado Nordeste) até $2000 \mathrm{~mm}$, no oeste, sendo que, em $86 \%$ da região chove entre 1000 e 2000 mm. Porém, existe uma grande variação, não somente na precipitação média anual, mas também na distribuição das chuvas; onde a época chuvosa tem duração de seis a oito meses (outubro a abril), ocorrendo neste periodo mais de $90 \%$ da precipitação pluvial total (Adámoli et al., 1987).

Estas chuvas geralmente são de curta duração e de alta intensidade, superando a capacidade de infiltração dos solos da região, com possibilidade 
de provocar erosão.

Há ainda, que se considerar a ocorrência de periodos secos dentro da época chuvosa, denominados veranicos, com durações mais freqüentes de oito (três vezes ao ano), dez (duas vezes ao ano) e treze (uma vez ao ano) dias, os quais podem comprometer o rendimento das culturas (Wolf, 1977).

A radiação solar varia em torno de $450 \mathrm{cal} \mathrm{cm}^{-2} \mathrm{dia}^{-1}$, com insolação de sete a dez horas por dia, não representando limitação ao cultivo de plantas anuais (Goedert, 1980), já que a taxa de radiação solar limitante para as plantas, segundo Ferraz (1987), é de $250 \mathrm{cal} \mathrm{cm}^{-2} \mathrm{dia}^{-1}$.

O relevo é plano a suave ondulado. As principais unidades de solos que ocorrem na região são: latossolos, ocupando $56 \%$ do total; areias quartzosas, $20 \%$ do total; $10 \%$ de lateritas hidromórficas; $9 \%$ de litossolos e, em menores quantidades, os podzólicos (Sanchez, 1974). Contudo, os solos predominantes são os latossolos, dos quais $85 \%$ são de baixa fertilidade (Cunha, 1994), tornando-se mais problemáticos após intensivo revolvimento. $O$ regime de umidade destes solos é, na maior parte, ústico e o regime de temperatura é isohipotérmico (Sanchez, 1974).

A ocupação de terras nesta região é, em sua maior parte, a de terras aptas à exploração agropastoril, com $73,6 \%$ do total destinadas à lavouras, pecuária e reflorestamento, $12 \%$ são áreas de preservação permanente e $14,4 \%$ permitem atividade pecuária e agrícola com restrições (Cunha, 1994). Porém, se não se reverter o quadro de uso incorreto dos recursos naturais desta região, as áreas inaptas passarão a ser utilizadas, prejudicando seu potencial produtivo. 


\subsection{Patamar de Produtividade}

Atualmente, os Cerrados respondem por cerca de $30 \%$ da produção nacional de soja, milho, feijão, trigo e café e abriga cerca de $40 \%$ do rebanho bovino nacional (Macedo ${ }^{1}, 1996$ ).

Segundo Klink et al. (1995) a região contribui com $25 \%$ na produção brasileira de soja, $16 \%$ na de milho, $13 \%$ na de arroz, $11 \%$ na de feijão, $8 \%$ na de café e $5 \%$ na de mandioca; sendo estes valores muito expressivos.

A maioria das culturas anuais se concentra no período de outubro a abril, quando ocorrem 80 a $90 \%$ do total anual de precipitações pluviais. Contudo, a prática da irrigação tem proporcionado perenização da produção e aumentos substanciais no rendimento das culturas.

$\mathrm{Na}$ Tabela 1 observa-se a situação estimada da produção agrícola na Região dos Cerrados utilizando-se toda a área disponível. Contudo, hoje, mais de um quarto da produção brasileira de grãos (estimada em 80 milhões de toneladas) é originária dos cerrados, como mostra a Tabela 2 (Goedert, 1989).

A comparação da situação atual (Tabela 2) com a potencial (Tabela 1) revela o longo caminho a ser percorrido na busca por maior eficiência nos processos produtivos.

Balbino (1997), apresenta os índices de rendimentos atuais e potenciais para algumas culturas na região (Tabela 3 ), os quais mostram o cenário de desigualdade entre o estoque tecnológico disponivel e a sua utilização pelo produtor; muito embora, tecnologias inapropriadas têm sido geradas e fomentadas por não se considerar todas as variáveis do processo de produção.

\footnotetext{
${ }^{1}$ MACEDO, J. Os solos da região dos Cerrrados. Palestra apresentada no 25. Congresso Brasileiro de Ciência do Solo, Viçosa, 1996.
} 
Tabela 1. Situação estimada da produção agrícola da região dos Cerrados, se utilizada toda a área disponível, empregando-se tecnologia apropriada.

\begin{tabular}{|c|c|c|c|}
\hline Atividade & Área (milhões ha) & Rendimento & Produção anual \\
\hline Sistemas de sequeiro & 60 & 2,5 tha $^{-1}$ ano $^{-1}$ & 150 milhões de t \\
\hline Sistemas irrigados & 10 & $4,0 \mathrm{tha}^{-1} \mathrm{ano}^{-1}$ & 40 milhōes de $t$ \\
\hline Bovinos (carne) & 90 & $100 \mathrm{~kg} \mathrm{ha}^{-1} \mathrm{ano}^{-1(1)}$ & 9 milhões de $t$ \\
\hline Florestas & 10 & $30 \mathrm{~m}^{3} \mathrm{ha}^{-1} \mathrm{ano}^{-1}$ & 300 milhões de $\mathrm{m}^{3}$ \\
\hline
\end{tabular}

Tabela 2. Situação da produção agrícola da região dos Cerrados, expressa e grãos, carne e madeira.

\begin{tabular}{cccc}
\hline Atividade & $\begin{array}{c}\text { Área } \\
\text { (milhões ha) }\end{array}$ & Rendimento & Produção anual \\
\hline Culturas anuais (grãos) & 12 & $1,5 \mathrm{t} \mathrm{ha}^{-1}$ ano $^{-1}$ & 18 milhões de t \\
Bovinos (carne) & 110 & $20 \mathrm{~kg} \mathrm{ha}^{-1} \mathrm{ano}^{-1}(1)$ & 2,2 milhões de $\mathrm{t}$ \\
Florestas (madeira) & 1 & $15 \mathrm{~m}^{3} \mathrm{ha}^{-1}$ ano & 15 milhões de $\mathrm{m}^{3}$ \\
\hline Rendimento obtido considerando-se uma taxa de lotação de 0.4 UAVha e abate aos quatro anos, com \\
200 kg de carne por animal. Fonte: CPAC-EMBRAPA, 1988. In: Pesquisa Agropecuária Brasileira, 1989.
\end{tabular}


Tabela 3. Índices de rendimentos atuais e potenciais de algumas culturas.

\begin{tabular}{cccccc}
\hline & \multicolumn{2}{c}{ Atual $\left(\mathrm{t} \mathrm{ha}^{-1}\right)$} & & \multicolumn{2}{c}{ Potencial para os Cerrados $\left(\mathrm{t} \mathrm{ha}^{-1}\right)$} \\
\cline { 2 - 3 } \cline { 5 - 6 } Cultura & Brasil & Cerrados & & $\begin{array}{c}\text { Lavouras } \\
\text { comerciais } \\
\text { tecnificadas }\end{array}$ & $\begin{array}{c}\text { Resultados } \\
\text { obtidos pela } \\
\text { pesquisa }\end{array}$ \\
\hline Milho & 2,0 & 2,0 & & 7,6 & 13,6 \\
Soja & 1,8 & 2,0 & & 4,0 & 5,0 \\
Feijão & 0,4 & 0,4 & & 2,0 & 4,0 \\
Feijão irrigado & 1,3 & 1,6 & & 2,5 & 4,2 \\
Arroz & $1,7^{1}$ & $1,2^{2}$ & & $3,1^{1}$ & 4,8 \\
Trigo & 1,7 & 2,0 & & 2,7 & 3,5 \\
Trigo irrigado & 1,7 & 3,8 & & 5,5 & 8,0 \\
\hline
\end{tabular}

'Média de arroz de sequeiro e irrigado; ${ }^{2}$ Média de arroz de sequeiro.

\subsection{Sistema de semeadura convencional}

\subsubsection{Implicações da exploração inadequada}

A maior parte dos solos do Brasil são ácidos, deficientes em nutrientes e com baixos teores de matéria orgânica, principalmente aqueles situados na região dos Cerrados.

Aliado a estes fatores geomorfológicos, o clima tropical e subtropical com temperaturas elevadas, chuvas intensas e o manejo incorreto destes solos redundam em degradação e perda do potencial produtivo.

Na região dos cerrados, a redução rápida do teor da matéria orgânica, em função de manejo incorreto, consiste em fator determinante de degradação.

O uso excessivo de um mesmo sistema de preparo de solo por vários anos, operando sistematicamente na mesma profundidade, tem provocado, entre outros problemas, a redução no rendimento das culturas. 
Segundo Dowding et al. (1967), o preparo ótimo de um solo deve proporcionar a adequação das condições que favoreçam o desenvolvimento das culturas e seu máximo rendimento a um custo mínimo operacional, especialmente sob o ponto de vista energético.

Os latossolos, sob vegetação natural, apresentam alto indice de agregação, grande profundidade e alta permeabilidade, características estas que Ihe conferem resistência à erosão. Porém, com a retirada da vegetação natural e seguidos cultivos, há a alteração dessas características, ocasionando degradação (Cardoso, 1993 e Ker et al., 1992).

A agregação de solos sob cultivo está associada ao processo mecânico de mobilização e à atividade das raízes e dos microrganismos (Oades, 1984). Assim, a estabilidade da estrutura do solo acaba por interferir diretamente sobre a permeabilidade, infiltração, temperatura, penetração de raízes, perda de nutrientes por lixiviação e, conseqüentemente, a sustentabilidade do solo (Fageria, 1989; Tormena, 1995).

A degradação da estrutura do solo e a erosão, como conseqüência, são os fatores principais que comprometem a sustentabilidade da agricultura no Cerrado (Fageria, 1989).

$\mathrm{Na}$ agricultura convencional ou na recuperação de pastagens, o uso exclusivo de implementos inadequados compacta as camadas subsuperficiais, desestrutura e pulveriza a camada superficial do solo, favorecendo a comunidade de plantas invasoras e a erosão hídrica e eólica; fatores estes que tornam duvidosa a viabilidade da monocultura a longo prazo (Sorrenson \& Montoya, 1989).

De acordo com dados levantados pela EMBRAPA, citados por Resck (1996), no Brasil em 1991, apenas $9,4 \%$ dos defensivos aplicados cumpriram sua função, o restante contaminou o solo e a água devido a erosão. Da mesma forma, do total de fertilizantes aplicados $59 \%$ foram perdidos pela enxurrada ou atingiram o lençol freático. 
Segundo Bertoni \& Lombardi Neto (1985), a perda de solo para a cultura do algodão, no estado de São Paulo, é de $26,6 \mathrm{t} \mathrm{ha}^{-1} \mathrm{ano}^{-1}$, o que poderia provocar o desgaste total do solo em apenas 70 anos.

Segundo Lopes et al. (1987), 3 tha de residuo cultural, em média, foram suficientes para cobrir a superficie do solo em até $50 \%$, bem como indices de cobertura de $20 \%$ foram suficientes para reduzir as perdas de solo em 40 a $60 \%$, em relação ao solo descoberto, para soja e trigo e, milho, respectivamente.

Já Andreani (1997) relata que quando $60 \%$ do solo apresenta-se coberto com restos de cultura ocorre redução do processo erosivo de $80 \%$ e de $20 \%$ na perda de água devido a erosão.

Bragagnolo (1994) verificou que a produtividade das culturas, no estado do Paraná, aumentou entre 10 e $30 \%$ com o uso de práticas mecânicas e vegetativas de conservação do solo.

A compactação do solo ocorre pela diminuição sensivel do volume de macroporos, impedindo o crescimento das raízes e o movimento de água ao longo do perfil. A menor ou maior quantidade de matéria orgânica no solo influencia a formação destas camadas compactadas e, a presença de resíduos sobre a superfície e a menor mobilização contribuem para melhorar ou manter a estrutura do solo, representando maior estabilidade dos agregados, maior macroporosidade e menor massa específica.

Segundo Goedert (1980), os solos do cerrado têm capacidade de reter água para manter uma cultura, em pleno crescimento, apenas pelo período de 6 a 10 dias e este fato é agravado pelo limitado desenvolvimento radicular.

Outro efeito importante dos sistemas convencionais de preparo refere-se à redução da capacidade de infiltração de água, onde, sob vegetação natural o indice de infiltração chega até $100 \%$, reduzindo para menos de $40 \%$ em solos sob cultivo intenso (Vasconcelos \& Landers, 1994). 
Porém o efeito da compactação no rendimento das culturas depende de umidade do solo no momento do crescimento radicular, tornando assim, difícil o seu reconhecimento em algumas condições (Freitas,1991).

A utilização de quantidades inadequadas de fertilizantes e o desbalanço de nutrientes têm resultado em baixos rendimentos médio das culturas, assim como as queimadas que concorrem para o empobrecimento do solo, ocasionando a destruição da matéria orgânica, a qual representa de 50 a 80\% da CTC destes solos, reduzindo a atividade biológica, a capacidade de retenção de água e nutrientes e aumentando a suscetibilidade à erosão.

\subsection{Sistema de plantio direto}

\subsubsection{Plantio direto na região dos cerrados: problemas para sua adoção}

Segundo Gassen \& Gassen (1996), talvez o maior desafio do sistema de plantio direto na região dos Cerrados é a manutenção da cobertura vegetal na superfície do solo e da matéria orgânica, além do desenvolvimento de uma atividade biológica e de raizes profundas que permitam a absorção de água pluvial. O clima com temperaturas elevadas no inverno e precipitações reduzidas de maio a outubro determinam a necessidade de manejo específico da cobertura do solo, do controle de pragas e de plantas daninhas.

A manutenção de restos culturais na superficie do solo provoca alterações no ambiente edáfico, como redução do processo erosivo, modificações dos valores de umidade e temperatura do solo, elevação da taxa de infiltração e armazenamento de água por períodos mais prolongados e maior disponibilidade de nutrientes.

Para Vasconcelos \& Landers (1994) a obtenção de 2 safras de sequeiro por ano nos Cerrados, como alternativa dos investimentos em irrigação, será 
fundamental para a sustentabilidade da agricultura na região, objetivando sempre a proteção do solo, promovendo maior quantidade de resíduos manejados na superfície sem incorporação ao solo. Entretanto a exploração econômica adequada neste período torna-se difícil pela condição de clima seco.

A utilização de rotação e seqüência adequada de culturas, possibilitada pelo uso da irrigação, propiciará a formação de palhada contribuindo para o controle de plantas daninhas, pragas e doenças, manutenção da matéria orgânica, redução das perdas de solo e água por erosão e maior resistência aos veranicos.

Nos solos intemperizados e fortemente microagregados, como os latossolos do Cerrado, a matéria orgânica é importante para o seu condicionamento e manutenção de suas propriedades químicas e físicas.

Segundo Cobucci et al. (1996) as espécies de plantas daninhas anuais tendem a diminuir no plantio direto, com importante aumento das espécies perenes. O não revolvimento do solo interfere na penetração da luz, na umidade e na temperatura e a presença de resíduos vegetais na superfície, bem como podem resultar na inibição da germinação de sementes de inúmeras espécies por impedimento físico ou efeitos alelopáticos.

\subsubsection{Efeito nos atributos químicos e físicos do solo}

O sistema de plantio direto produz mudanças nas propriedades físicas, químicas e biológicas do solo, cujos efeitos se refletem diretamente na fertilidade e na eficiência de aproveitamento dos nutrientes pelas plantas.

Dentre os aspectos envolvidos destacam-se as alterações de temperatura e umidade na camada arável, cujos efeitos interferem na atividade biológica responsável pela mineralização da matéria orgânica, influenciando os processos de solubilização e liberação dos nutrientes nela contidos. 
A não mobilização do solo favorece a maior homogeneidade estrutural, a estabilidade dos agregados e a uniformidade capilar. Assim, há maior infiltração e armazenamento de água, que afeta a movimentação e redistribuição de compostos de alta solubilidade no perfil do solo. A localização dos adubos e corretivos nas camadas superficiais, sem a incorporação, também altera a distribuição dos nutrientes, influenciando a sua disponibilidade e aproveitamento pelas plantas.

A presença de impedimento químico no solo, além do físico, condiciona a ocorrência de um sistema radicular superficial com reduzido desenvolvimento. Este tipo de impedimento é representado pela ausência de cálcio ou excesso de alumínio em profundidade, sendo agravado pelas aplicações de corretivos apenas nas camadas superficiais.

A presença de sistema radicular com distribuição superficial e pouco desenvolvido constitui-se em fator limitante para o crescimento e produção das culturas. A ausência de raizes profundas e com taxa de ramificação inadequada pode significar maior suscetibilidade a seca e menor capacidade de utilização dos nutrientes presentes no solo. Esta situação também pode contribuir para a ineficiência no aproveitamento direto dos nutrientes e da água (Favarin \& Fancelli,1989).

Em vista da ausência de revolvimento do solo, o plantio direto pode promover o acúmulo de matéria orgânica (Parra, 1986 e Sá, 1993) e nutrientes nas camadas superficiais (Muzilli, 1983; Centurion et al., 1985 e Merten \& Mielniczuk, 1991) e acidificação superficial (Blevins et al., 1983).

De acordo com Parra (1986), nem sempre o manejo diferenciado do solo apresenta resultados coerentes quanto à distribuição e acúmulo de nutrientes. As diferentes condições de clima e solo, espécies vegetais e implementos agricolas podem alterar estes resultados.

Em plantio direto pode ocorrer períodos de deficiência de nitrogênio em relação ao preparo convencional do solo, devido ao movimento descendente 
da água no solo que acarreta maior lixiviação de nitratos, já que a não movimentação do solo neste sistema evita a alteração de sua capilaridade. Outro ponto refere-se a menor evaporação da água nos solos sob plantio direto, provocando menor movimento de nitratos para a superfície e ainda, bem como a menor taxa de mineralização da matéria orgânica característica desse sistema.

Quanto ao potássio, tem evidenciado poucas alterações na sua disponibilidade quando comparado ao preparo convencional. Sob plantio direto o potássio tende à maior redistribuição no perfil do solo, provavelmente devido a maior infiltração de água neste sistema. Sob preparo convencional ocorre o mesmo devido a mobilização constante do solo, acarretando a lixiviação do referido elemento.

No plantio direto o fósforo concentra-se na camada superficial, juntamente na faixa de acúmulo de matéria orgânica, resultado da menor fixação deste elemento pelo não revolvimento contínuo do solo, acarretando maior eficiência da fertilização fosfatada (Muzilli, 1986). Sob plantio direto existe menor competição pelos sítios de adsorção do fósforo, o que permite a manutenção dos valores elevados desse elemento com menor quantidade de fertilizantes aplicada.

O cálcio e o magnésio apresentam tendência de acúmulo na superfície sob plantio direto (Muzilli, 1986). Da mesma forma, há a tendência de diminuição gradativa da disponibilidade à medida que se aprofundam no perfil do solo, seja em plantio direto ou em preparo convencional.

Atenção maior deve ser dada ao cálcio, já que este elemento é essencial ao crescimento das raízes e apresenta somente translocação ascendente na planta. Portanto, em plantio direto, existe a necessidade da utilização de técnicas que favoreçam a plena distribuição do cálcio no perfil do solo (Favarin \& Fancelli, 1989). 
Sob plantio direto a mineralização da matéria orgânica é mais lenta e gradual não proporcionando acúmulo de ácidos orgânicos na superfície, além do que, a amplitude térmica é menor e o teor de água na superficie promovem o efeito de diluição da concentração dos ácidos liberados, resultando na tendência de pH mais elevado (Anghinoni \& Saler, 1995).

O grande problema com a acidificação acontece na superfície do solo, devido à aplicação de adubos nitrogenados em cobertura, o que pode ser facilmente corrigido por aplicação superficial de calcário, sem a necessidade de incorporação.

Os problemas de deficiência de micronutrientes têm se acentuado em várias regiões do país. Nas áreas de Cerrado e há muito cultivadas, nota-se deficiência de cobre, boro e zinco.

A distribuição dos micronutrientes no perfil do solo relaciona-se diretamente, na maior parte dos casos, com o teor de argila e matéria orgânica presentes nos horizontes do solo.

A matéria orgânica retém fortemente o cobre e, por isso, sob plantio direto este pode se concentrar nas camadas superficiais. Os teores de manganês e zinco também apresentam-se, sob plantio direto, concentrados na camada superficial (Motta \& Prevedello,1995). Segundo os mesmos autores, a cultura do milho pode apresentar deficiência de zinco por efeito antagônico do fósforo principalmente se a temperatura e umidade forem baixas ou quando a umidade for elevada.

Além disso, a tendência de acúmulo superficial de $\mathrm{P}, \mathrm{K}, \mathrm{Ca}$ e Mg (Lal, 1976 e Centurion et al., 1985) pode promover a concentração de raízes nessa profundidade e limitar a capacidade das plantas em absorver água e nutrientes em profundidade.

Para o nitrogênio e potássio, por serem elementos móveis e passiveis de lixiviação acentuada, a presença de maior volume de raizes, em profundidade, 
pode garantir menores perdas e contribuir para o incremento da eficiência do processo produtivo.

No caso do fósforo seu efetivo aproveitamento pode ser afetado por tratar-se de um elemento praticamente imóvel e dependente do processo de difusão para seu contato com o sistema radicular, o qual é função da área externa do sistema radicular e da presença de água.

A redistribuição dos nutrientes do solo, no sistema de plantio direto, está estreitamente relacionada aos efeitos químicos e físicos do material orgânico acumulado na superfície. Com a resteva, ocorre o acúmulo do material orgânico e inorgânico de baixa mobilidade na superfície do solo e redistribuição do perfil de compostos de alta solubilidade. A passagem de material orgânico para compostos de alta solubilidade resultará em alterações no comportamento dos nutrientes, devido às interações com algumas variáveis de natureza física, como a maior disponibilidade de água por períodos mais prolongados, menor variação de temperatura, maior efeito de capilaridade e maior aeração neste sistema. Ou seja, devido a maior infiltração de água, maior armazenamento e menor evaporação, ocorre uma redistribuição, no perfil do solo, dos compostos de alta solubilidade, como o nitrogênio e o potássio. A influência dos resíduos na atividade biológica é diretamente proporcional a sua relação $\mathrm{C} / \mathrm{N}$, que está ligada à redistribuição dos nutrientes no perfil do solo.

Segundo Resck (1996), os latossolos da região dos cerrados na Bahia, perderam, em 5 anos de cultivo, cerca de 45 a $68 \%$ de matéria orgânica, ocasionando redução na CTC $(0-15 \mathrm{~cm})$ na ordem de 29 a 53\%, respectivamente, para Latossolo Vermelho-Escuro (LV) e Latossolo VermelhoAmarelo (LA).

Após 5 anos de plantio direto, Bayer \& Mielniczuk (1997) verificaram aumento nos teores de carbono orgânico total e da CTC do solo, apenas nas camadas superficiais. 
No plantio direto houve maior concentração de $\mathrm{P}, \mathrm{K}, \mathrm{Ca}$ e matéria orgânica e maior CTC nos $5 \mathrm{~cm}$ superficiais. No preparo convencional o pH foi mais elevado na camada de 5 a $10 \mathrm{~cm}$, o que contribuiu para a elevação da CTC pelas cargas dependentes de pH (Merten \& Mielniczuk, 1991).

Silva et al. (1991), em experimento instalado em Planaltina, avaliaram a resposta de soja e trigo sob irrigação à três niveis de movimentação de solo: preparo convencional, cultivo mínimo e plantio direto. Estatisticamente os resultados não diferiram entre si, mas verificou-se um aumento dos teores de fósforo na camada de 0 a $10 \mathrm{~cm}$ de profundidade no plantio direto e cultivo mínimo, enquanto que no convencional a distribuição foi mais uniforme.

Silveira et al. (1994), realizando estudo de sistemas irrigados, verificaram que os teores dos nutrientes $\mathrm{Ca}, \mathrm{Mg}, \mathrm{P}$ e K e o pH aos $0-20 \mathrm{~cm}$ foram mais elevados na aração convencional $(15 \mathrm{~cm})$ que na aração profunda $(30 \mathrm{~cm})$, devido ao menor volume de solo revolvido. Contudo, o teor de $\mathrm{P}$, foi maior na aração profunda devido ao maior revolvimento do solo, pois tal procedimento conduziu o citado elemento às camadas mais profundas.

Mullins et al. (1980), estudaram o efeito de preparo do solo sobre a distribuição de nutrientes no solo e o rendimento do feijoeiro durante três anos. Os métodos de preparo do solo, plantio direto, preparo reduzido com grade de dentes, com grade de discos e preparo convencional, não afetaram $\circ \mathrm{pH}$ e o rendimento da cultura; porém, os teores de fósforo, na camada de 10 a $15 \mathrm{~cm}$, e de potássio, nas de 5 a $15 \mathrm{~cm}$ de profundidade, foram mais elevados no sistema convencional que no direto.

Sá (1997) estudou métodos de incorporação de calcário, com arado de discos, aivecas e escarificador, e de aplicação superficial e observou a existência de tendência de redução do $\mathrm{pH}$ ao longo dos anos, principalmente após a cultura do milho, devido, provavelmente, ao efeito acidificante do fertilizante nitrogenado, exceto quando utilizou-se o arado de aivecas. 
Vieira e Muzilli (1984) trabalhando com um Latossolo Vermelho-Escuro e com sistemas de preparo convencional, plantio direto e rotação de culturas, verificaram, após quatro anos de cultivo, na profundidade de $10 \mathrm{~cm}$, um aumento na massa específica do solo para o plantio direto, embora sem significancia estatística. Por outro lado, Albuquerque et al. (1995) não verificaram aumento da massa específica do solo no plantio direto, em estudos semelhantes.

No plantio direto o maior adensamento das camadas subsuperficiais é, muitas vezes, compensado pela continuidade dos poros resultantes da ação da mesofauna e da presença de raízes (Chaves, 1997).

Voorhees \& Lindstrom (1984) relatam que, em solos sob manejo conservacionista, são necessários de 3 a 4 anos para que haja 0 desenvolvimento de porosidade mais favorável na camada de 0 a $15 \mathrm{~cm}$, quando comparado a solos arados continuamente.

Simpson \& Gumbs (1985b) concluíram que o preparo convencional melhorou a porosidade total, a macroporosidade total e a massa especifica do solo, favorecendo o desenvolvimento das raízes.

Experimento conduzido por 7 anos pela OCEPAR (1990) com preparo convencional (arado de discos e grade), preparo mínimo (arado de aiveca e escarificador) e plantio direto, verificou-se que o plantio direto apresentou aumento da massa especifica do solo, decréscimo na macroporosidade e maior disponibilidade de água. Os preparos reduzidos apresentaram maior estabilidade de agregados e menor massa específica do solo. $O$ arado de aivecas incorporou cálcio e magnésio a profundidades maiores, contribuindo para a diminuição da concentração de alumínio trocável aos $15-30 \mathrm{~cm}$ de profundidade. Os rendimentos de soja e trigo foram, na maioria dos anos, superiores para o uso do arado de aivecas em relação aos demais sistemas. 


\subsection{Rendimento em plantio direto e convencional}

Muitos estudos sobre sistemas de produção têm sido realizados buscando controle da erosão, manutenção da fertilidade do solo, maior rendimento das culturas e redução dos custos operacionais, proporcionando assim maior estabilidade à atividade agricola.

O plantio direto constitui importante ferramenta para se alcançar estes objetivos, podendo resultar em aumento médio de rendimento de até $8 \%$ para - milho, feijão, soja e outros produtos (Gentil, 1995). Segundo o mesmo autor a maior incremento no plantio direto pode ser resultado da época correta de semeadura, porém não há pesquisas conclusivas a respeito.

Kapusta \& Strieres (1976) verificaram que o rendimento de milho no plantio direto foi influenciado primeiramente, pelo grau de controle de plantas daninhas e por efeito secundário sobre as plantas de milho devido as mudanças de temperatura e umidade.

Segundo Muzilli (1981), a cultura da soja é uma das mais beneficiadas pelos efeitos favoráveis do plantio direto nos processos de germinação das sementes, emergência e desenvolvimento inicial das plantas.

Segundo Sidiras et al. (1983) a cultura da soja apresentou um rendimento $33 \%$ superior no plantio direto (2593 $\mathrm{kg} / \mathrm{ha}$ ) em comparação ao convencional (1948 kg/ha), numa média de 3 anos de experimentação, cujos resultados foram atribuídos ao maior número de plantas e a maior massa dos grãos.

Sorrenson \& Montoya, citados por Derpsch et al. (1991), reuniram dados de experimentos realizados no Paraná e verificaram que 0 plantio direto proporcionou aumento de rendimento de $19 \%$ para a soja, $8 \%$ para o trigo e $4 \%$ para o feijão; todavia, para o milho, os rendimentos obtidos foram semelhantes ao preparo convencional e ao cultivo mínimo. Os autores concluíram que o 
plantio direto não diminui o rendimento das culturas, favorecendo estas em anos de seca, principalmente.

Rüedell (1995) avaliou o rendimento de milho, soja e trigo em resposta ao manejo de solo, durante 9 anos de experimentação. O rendimento do milho foi significativamente superior no plantio direto em relação ao convencional, em todos os anos, principalmente nos anos com deficiência hídrica acentuada. $O$ mesmo autor afirmou que o aumento do rendimento do milho em plantio direto poderia estar relacionado à melhor distribuição radicular no perfil do solo.

Stone \& Moreira (1995) compararam o efeito do preparo de solo com grade aradora, arado de aiveca, escarificador e plantio direto no rendimento e uso de água pelo feijoeiro. O sistema de plantio direto propiciou maiores rendimentos com menor consumo de água, devido, provavelmente, aos efeitos favoráveis da palhada nas condições hídricas e características edáficas do solo.

O rendimento da soja e trigo sob plantio direto foram 39 e $22 \%$ superiores, respectivamente, na escarificação este aumento foi de $13 \%$ para ambas as culturas, comparados ao preparo convencional (Sorrenson \& Montoya, 1989).

Para Derpsch et al. (1991) os rendimentos de soja e trigo em sucessão, em um Latossolo Roxo no Paraná, foram significativamente maiores no plantio direto em relação ao plantio convencional e a escarificação apresentou rendimentos intermediários.

Sidiras et al. (1983) obtiveram maiores rendimentos de soja em plantio direto, comparado ao plantio convencional e cultivo mínimo com escarificador, os quais não diferiram estatisticamente, porém a escarificação apresentou um rendimento operacional $60 \%$ superior.

Michel Jr. et al. (1985), estudaram o efeito de dois sistemas de preparo de um solo de textura arenosa utilizando escarificador e arado de aivecas, nas culturas de feijão, milho e cana-de-açúcar. O rendimento das culturas foram 
semelhantes nos dois sistemas, porém a escarificação consumiu $40 \%$ menos tempo, energia e combustível, comparado ao preparo convencional.

Muzilli et al. (1981) verificaram, em pesquisas realizadas no IAPAR, que os rendimentos médios da soja se equivalem em diferentes sistemas de cultivo. Ainda, o mesmo autor também observou rendimentos semelhantes de soja $e$ milho em preparo convencional e plantio direto durante 4 safras. Neste contexto, Van Doren et al. (1976) observaram a mesma tendência para o milho; Simpson \& Gumbs (1985a) e Zaffaroni et al. (1991) também não observaram diferenças significativas no rendimento das culturas de milho e feijão, comparando-se os diferentes sistemas.

Voorhees et al. (1989) não encontraram diferenças consistentes de rendimento de milho afetados pela presença de compactação de superfície e da superfície, concluindo que, em algumas situações, a maior massa especifica do solo pode não ser prejudicial para o rendimento das culturas.

Segundo Baumer \& Bakermans (1973), os efeitos dos sistemas de cultivo do solo se tornam inconsistentes quando avaliados mediante condições ambientais variáveis, como ocorrem de um ano para o outro, representadas por oscilações de clima, presença de plantas daninhas, pragas e doenças e o próprio manejo da lavoura.

Segundo Fancelli \& Dourado Neto (1997), independente da tecnologia aplicada, as condições climáticas e o tempo em que a cultura do milho é submetida constituem-se importantes fatores de produção. Dentre os elementos de clima, a disponibilidade de luz determina a densidade e o peso dos grãos, influenciando diretamente o rendimento da cultura.

Fischer \& Palmer, citados por Fancelli \& Dourado Neto (1997), verificaram que uma redução de $50 \%$ na radiação incidente no período do florescimento e enchimento de grãos reduziram de 40 a $50 \%$ o rendimento em grãos de milho. 
Da mesma forma Siemens \& Oschwald (1978) observaram que o rendimento da cultura do milho tendeu a ser menor em sistemas de preparo conservacionista (cultivo mínimo e plantio direto) do solo que no sistema de preparo convencional, sendo que a mesma tendência foi observada por Bayer et al. (1988), porém os resultados não diferiram estatisticamente.

Sob o plantio direto, deve-se considerar, a lenta degradação da matéria orgânica e a conseqüente imobilização momentânea do nitrogênio por microrganismos, o que ocasiona a carência inicial para a cultura do milho, podendo afetar o rendimento (Sá, 1993). Da mesma forma a movimentação do íon nitrato, sob plantio direto, resulta em menor concentração deste no sistema (Thomas, 1973 e Sá, 1993).

Balbino \& Oliveira (1992b) estudaram, por 4 anos, o efeito de 5 preparos de solo (preparo convencional com arado de aivecas, preparo convencional com arado de discos, plantio direto, preparo convencional com grade e preparo mínimo com escarificador) sobre o rendimento de soja, milho e trigo em Latossolo Roxo eutrófico. Os autores concluíram que, de maneira geral, o plantio convencional com grade proporcionou menor rendimento de grãos. Para a soja os maiores rendimentos foram obtidos no preparo convencional com aivecas e com arado de discos. A cultura do milho apresentou respostas semelhantes ao sistema convencional com aivecas e plantio direto e o trigo ao convencional com aivecas, escarificação, plantio direto e convencional com discos. As variações de rendimento nos anos agrícolas estudados estão relacionados às condições climáticas do período, que minimizaram ou agravaram os efeitos das condiçōes edáficas sobre as culturas.

Em outro trabalho, Balbino \& Oliveira (1992a), estudaram o efeito da alternância dos sistemas de preparo acima citados por 2 anos no rendimento de trigo e soja. Para o trigo, independente do sistema de preparo anterior, o sistema de plantio direto apresentou o menor rendimento devido, provavelmente, ao baixo retorno de matéria seca pelas culturas anteriores (soja 
e trigo) e à alta taxa de decomposição da matéria orgânica, não permitindo a reposição da palhada na superfície. No caso da soja, não houve diferenças significativas dos efeitos de preparo de solo sobre o rendimento de grãos, porém os maiores rendimentos foram observados nos sistemas de preparo com mobilização mais profunda do solo.

Peixoto \& Eltz (1986) enfatizam que, no decorrer dos anos, pode haver menores rendimentos das culturas sob plantio direto devido a acidificação em profundidade, compactação e desequilibrios nutricionais, principalmente em anos climaticamente desfavoráveis.

\subsection{Rentabilidade em plantio direto e convencional}

Segundo Coimbra (1997), a utilização de indicadores econômicos, como custos variáveis, custos fixos, margem líquida e relação benefício/custo, no gerenciamento da atividade agrícola são fundamentais para a avaliação do sistema de produção adotado, permitindo a busca do ponto de equilíbrio entre eficiência técnica e rentabilidade.

De acordo com Turra (1998), devido as margens de lucro na agricultura estarem muito reduzidas, as estimativas de custos de produção constituem ferramentas interessantes para se estabelecer a viabilidade de uma cultura.

A estrutura do custo total de produção de uma cultura é composta por custos fixos, custos variáveis e custo operacional, sendo este último uma aproximação do custo variável, pois considera basicamente os gastos com o recurso variável e a depreciação de máquinas e juros de custeio (Neves \& Shirota,1985). Os custos fixos são referentes aos recursos necessários que independem do volume produzido, o que não ocorre com os custos variáveis.

Porém esta metodologia de análise ainda não inclui todos os encargos envolvidos nos custos de produção. Estes encargos podem ser diretos e 
indiretos e vão desde a remuneração da terra, remuneração do empresário até os custos ambientais (Neves \& Shirota,1985; Turra,1998).

A utilização de tecnologias menos impactantes ao meio ambiente, podem, a médio e longo prazo, reduzir os custos ambientais, os quais ainda não são computados no processo produtivo. Porém, subjetivamente, reconhece-se que os sistemas de produção convencionais, onde se busca produções melhores e rentabilidades maiores, acabam por onerar o processo produtivo, a médio e longo prazos.

Sob este aspecto, a EMBRAPASNLCS (1984), em levantamento realizado no Paraná, estimou o valor econômico da perda de macronutrientes provocada pela erosão laminar. Assim, a perda de $1,9 \mathrm{~kg} \mathrm{~N} / \mathrm{t}$ de solo resulta um custo de US $\$ 0,955 / \mathrm{kg}$; de $8,18 \mathrm{~g} \mathrm{P}_{2} \mathrm{O}_{5}$ (disponivel)/t solo acrescido de $400 \mathrm{a}$ $800 \mathrm{~g} \mathrm{P}_{2} \mathrm{O}_{5}$ (aplicado)/ t de solo resulta um custo de US $\$ 0,859 / \mathrm{kg}$, de $160 \mathrm{~g}$ $\mathrm{K}_{2} \mathrm{O} / \mathrm{t}$ de solo relaciona-se a um custo de US\$0,393kg;de $401 \mathrm{~g} \mathrm{MgO/t}$ de solo resulta um custo de US $\$ 0,068 / \mathrm{kg}$ e, de $927 \mathrm{~g} \mathrm{CaO} / \mathrm{t}$ de solo resulta um custo de $0,085 / \mathrm{kg}$ (Sorrenson \& Montoya, 1989).

Os custos da erosão, considerando apenas as perdas estimadas com base no valor dos nutrientes pode chegar a US $\$ 26,64 /$ ha. ano (com uma perda de solo de 10 tha.ano) no preparo convencional, caindo para US $\$ 13,73$ (perda de solo de 5 t/ha.ano) no cultivo mínimo e US $\$ 2,42$ (com uma perda de solo de 1 tha.ano) no plantio direto (Sorrenson \& Montoya, 1989).

Diante deste quadro, o sistema plantio direto concorre para a redução dos riscos decorrentes de irregularidades climáticas, porém, a viabilidade econômica do sistema dependerá das condiçōes especificas relacionadas a plantas daninhas presentes na área, das decisões de gerenciamento e do ritmo das operações, bem como da escolha de tecnologia adequada (Dillon, 1977; Gentil, 1995; Vasconcelos \& Landers, 1994).

Trabalhos mais antigos relatam maiores custos no plantio direto devido, principalmente aos gastos com herbicidas. 
Segundo Laurenti \& Fuentes (1981), comparando custos e rentabilidade em plantio direto e convencional para diversas culturas, não verificaram diferenças de custo variável (insumos e operaçōes), mas notaram existir uma ligeira tendência do custo ser maior em PD que em PC. Esta similaridade entre os custos nos dois sistemas é devido a compensação dos gastos com controle de plantas daninhas em relação a diminuição dos gastos com preparo de solo.

Os rendimentos de milho, soja e trigo sob plantio direto proporcionaram, respectivamente, ganhos de US $\$ 108,00$, US $\$ 59,00$ e US $\$ 19,00$ sob o plantio convencional. Os custos, em média, foram $12 \%$ maiores em plantio direto que em convencional. A análise conjunta dos dados avaliados permitiu concluir, nas condiçōes do experimento, que o plantio direto pode resultar em ganhos de 6 a $40 \%$ a mais que o preparo convencional, considerando apenas os aumentos nos rendimentos de grãos (Rüedell, 1995).

Shultz (1987) verificou que, no plantio direto, houve uma redução de $79 \%$ nos gastos com mão-de-obra, de $72,7 \%$ com combustível e lubrificantes, de $31,6 \%$ com depreciação e manutenção de máquinas; porém, houve um maior gasto com herbicidas $(389,6 \%)$ gerando um custo operacional $56,3 \%$ maior que no preparo convencional. Todavia, em plantio direto, o rendimento é maior quando se utiliza sistemas de rotações corretas, devido à melhor conservação do solo, melhor taxa de germinação, redução na perda de nutrientes pela erosão, bem como redução do consumo de combustivel, lubrificantes, mão-de-obra e nos investimentos com maquinário.

Em outras regiōes, os custos no plantio direto foram 5 a $6 \%$ maiores que no preparo convencional e 9 a $10 \%$ superiores aos custos da escarificação. O retorno econômico do plantio direto e escarificação foram, respectivamente, 488 e $254 \%$ superiores ao preparo convencional do solo (Sorrenson \& Montoya, 1989).

Derpsch et al. (1991), avaliando o custo de produção de soja, milho e trigo em quatro sistemas de preparo de solo, no período de 1977 a 1984 , 
determinou o menor custo de produção por hectare na soja sob preparo com escarificador, US $\$ 285$, enquanto que o milho sob plantio direto teve custo de US\$ 401/ha. Esta diferença, segundo o autor, foi devido ao maior consumo de herbicidas no sistema plantio direto, que é variável em função da presença de invasoras na área da rotação de culturas adotada.

Atualmente, com o desenvolvimento de moléculas de herbicidas mais eficientes, o plantio direto passou a ter custos menores com este insumo, evidentemente considerando-se a tecnologia adotada. Porém, ainda, o item com valor mais elevado na planilha de custos, continua sendo o herbicida, como observado por Sorrenson \& Montoya (1989), que encontraram, no plantio direto, custos com herbicidas mais elevado para a soja e o milho, perfazendo $25 \%$ dos custos operacionais totais, enquanto que, para os outros sistemas, o item mais oneroso foi representado pela adubação.

Um estudo econômico com sistemas de semeadura direta e preparo convencional realizado por Salomão (1990) revelou que os maiores rendimentos para o milho, soja e trigo foram obtidos no sistema de semeadura direta, com melhores resultados em termos de lucro, levando-se em consideração o risco envolvido. Neste caso, os principais componentes do custo para o preparo convencional foram o uso da terra, seguido da adubação, da operação de semeadura e do controle de plantas daninhas. Para o plantio direto, neste experimento, o controle de plantas daninhas foi o segundo na escala de custo, com um dispêndio que variou, de acordo com a rotação de culturas adotada, 85 a $169 \%$ a mais que o preparo convencional.

Landers (1995) encontrou pouca diferença nos custos de plantio direto e convencional para soja. No plantio direto, o principal componente de custo foi representado pelos herbicidas $(20,5 \%)$, enquanto que no plantio convencional o custo deste insumo foi de $7,7 \%$, do total. O grande diferencial foram as operações de preparo do solo e manutenção de terraços, representando $8 \%$ do custo total no plantio convencional. O custo total por hectare foi de US $\$ 378,49$ 
no plantio direto e US $\$ 390,46$ no plantio convencional. Os demais itens que compuseram a planilha de custos como sementes, tratamento de sementes, inseticidas e custos administrativos, foram os mesmos para os dois sistemas.

Segundo Silveira et al. (1994), o insumo com maior custo foram o fertilizante e o corretivo, considerando o preparo do solo, a semeadura, o uso de defensivos, colheita, sementes e irrigação, para o milho foi 24,3 sc/ha, para o arroz $17,4 \mathrm{sc} / \mathrm{ha}, 16,7 \mathrm{sc} / \mathrm{ha}$ para o trigo e 6,4 sc/ha para o feijão. A cultura do milho apresentou a maior relação benefício/custo, 1,91 , seguido do feijão, com 1,43 , trigo, 1,25 e arroz, com 0,82.

Ainda assim, há mais de 2 décadas, Siemens \& Oschwald (1978) encontraram resultados semelhantes de custos de produção para diferentes sistemas de produção, onde estes foram equivalentes para os sistemas de preparo convencional e conservacionista (plantio direto e escarificação) na cultura do milho.

Vasconcelos \& Landers (1994) mencionaram que os custos diretos da lavoura de soja em 91/92 foram 10\% menores quando comparados ao preparo convencional, com uma margem bruta $7 \%$ superior, embora 0 rendimento médio em plantio direto tivesse sido menor $(2511 \mathrm{~kg} / \mathrm{ha})$ que no preparo convencional ( $2650 \mathrm{~kg} / \mathrm{ha}$ ). Ressaltaram ainda, que o controle total da erosão obtido, mesmo com $70 \%$ de cobertura, já justificaria a adoção do manejo dos resíduos na superfície.

Shultz (1987) concluiu, para a soja, que para o sistema de plantio direto apresentar rentabilidade idêntica ao preparo convencional é necessário produzir pelo menos 2,1 sacos de soja por hectare a mais.

Ainda, muitos estudos avaliam aspectos de desempenho operacional e consumo de óleo diesel sob diferentes sistemas de manejo.

Hoogmoed \& Derpsch (1985) avaliaram o desempenho operacional de um arado de discos, de uma grade aradora e de 4 tipos de escarificadores, em um Latossolo Vermelho-Escuro. O preparo de solo que proporcionou maior 
consumo de combustivel foi o realizado com arado de discos, devido a sua menor capacidade de trabalho. Já, a grade aradora e os escarificadores, requereram menor consumo de combustivel e apresentaram maior capacidade de trabalho. No trabalho citado, não foram verificadas diferenças significativas quanto ao consumo de combustivel em relação ao volume de solo mobilizado por hectare.

Bowers Jr. (1989), pesquisando em 12 séries de solos de diferentes texturas, verificou que a operação com arado de aiveca consumiu mais combustivel por hectare, seguido da escarificação, gradeação e semeadura direta. O consumo de combustível para a aivecagem variou de 25,96 a 40,39 I/ha, de 20,88 a 28,36 I/ha para escarificação e gradeação e de 2,31 a 3,24 l/ha para semeadura direta.

De acordo com Derpsch (1997), o plantio direto pode representar uma redução entre $64 \%$ e $74 \%$ no consumo de óleo diesel.

Em áreas sob plantio direto já estabilizado, verificou-se que o investimento em força de trator passou de 0,7-0,9 hp/ha, no preparo convencional, para $0,4-0,5 \mathrm{hp} / \mathrm{ha}$ com plantio direto, representando uma redução de mais de $40 \%$ no investimento (Vasconcelos \& Landers, 1994). Resultados semelhantes foram obtidos por Landers (1995), no qual as reduções em hp foram de $44 \%$, em média.

Vários autores ainda têm relatado resultados satisfatórios quanto a economia de fertilizantes no sistema plantio direto. Porém, deve-se ressaltar que, são inúmeros os fatores que afetam a disponibilidade de nutrientes no solo e sua conseqüente absorção pelas plantas. Adubações adequadas que resultem em um melhor equilibrio de nutrientes no solo e na planta, consistem em estratégia ideal para se obter retorno econômico satisfatório com redução de riscos.

Laurenti \& Fuentes (1981), estudando os sistemas plantio direto e convencional, concluíram que o uso contínuo do sistema plantio direto pode 
levar, a longo prazo, a uma economia de fertilizantes fosfatados, porém contribuir para o aumento dos gastos com fertilizantes nitrogenados.

Muzilli (1981) notou uma redução de até $50 \%$ na aplicação de adubo fosfatado sob plantio direto, com economia de, aproximadamente, US\$26/ha na produção de soja, milho e trigo.

Segundo Sá (1995), a economia com fertilizantes em plantio direto pode chegar a $25-30 \%$, dependendo da rotação de culturas adotada e da escolha de genótipos. O custo com fertilizantes pode ser reduzido em US $\$ 30-50,00$ por hectare (Rüedell, 1995).

Salton \& Hernani (1997) avaliaram a resposta de variedades de soja em 3 niveis de adubação $(0,250$ e $450 \mathrm{~kg} / \mathrm{ha}$ de $0-20-20)$ em solo de alta fertilidade, sob plantio direto e concluiram que não houve diferença significativa dos rendimentos para as diferentes dosagens. Porém houve a tendência destes serem maiores na dosagem de $450 \mathrm{~kg} / \mathrm{ha}$. Todavia o referido ganho em rendimento não cobriu os custos com a adubação adicional. Este resultado mostra a ausência de resposta à adubação em função de situações relacionadas a alta fertilidade atual do solo em estudo, indicando ser aceitável a adubação que vise apenas a reposição dos nutrientes exportados pelos grãos. 
Segundo Fancelli (1997) a consideração exclusiva da correção da fertilidade do solo e do nivel de adubação, freqüentemente não apresentam resultados consistentes se não forem aliados ao manejo, ao clima e às características fisiológicas e fenológicas da espécie.

A rentabilidade do produtor está relacionada a eficiência no uso dos recursos, dados pelos custos de produção e intervenção técnica no momento correto. Porém, os fatores rendimento, comercialização e preços pagos ao produtor são também determinantes na obtenção de boa rentabilidade no setor agrícola (FNP, 1997).

Assim, além dos fatores técnicos, devem ser observadas estratégias de comercialização e tendências de mercado para se garantir a viabilidade econômica do sistema de produção considerado. 


\section{MATERIAL E MÉTODOS}

\subsection{Caracterização da área experimental}

O presente trabalho foi realizado na Fazenda Três Irmãos, localizada em Santa Helena, município da região Sudoeste do Estado de Goiás, a 1748'49" de latitude Sul e $50^{\circ} 35^{\prime} 49^{\prime \prime}$ de longitude Oeste, a 615 metros de altitude.

A precipitação média anual é de $1643 \mathrm{~mm}$ (média de dez anos, 1980 a 1990) com $85 \%$ do total de chuvas concentrados, principalmente, nos meses de outubro a março. A freqüência de veranicos nesta região é, para o mês de janeiro, de pelo menos um por ano, igual ou superior a dez dias e em fevereiro um veranico a cada um ano e meio.

O sistema de plantio direto foi introduzido na propriedade a partir de 1988, perfazendo, atualmente, 700 hectares cultivados sob este sistema. As culturas comumente exploradas no verão são o milho e a soja, e no outono/inverno a crotalaria, milho, feijão e sorgo.

A propriedade agricola em questão apresenta ainda, alta taxa anual de ocupação do solo pelas culturas, com média de 2,0 a 2,6 culturas por ano.

O solo da área utilizada para o ensaio é classificado como Latossolo Roxo eutrófico, com textura argilosa. 


\subsection{Condução dos experimentos}

Foram analisadas as características químicas e físicas do solo antes da instalação dos experimentos e os resultados das análises revelaram alta concentração de nutrientes na camada de $5 \mathrm{~cm}$ superficiais e a presença de uma camada compactada de 10 a $20 \mathrm{~cm}$ de profundidade (Tabelas 4, 5 e 6).

Tabela 4. Análise química de macronutrientes, $\mathrm{pH}$ e matéria orgânica da gleba 3-A, cultivado no sistema de plantio direto no período 1988/1996 ${ }^{1}$.

\begin{tabular}{lcccccccc}
\hline \multirow{2}{*}{$\begin{array}{c}\text { Profundidade } \\
(\mathrm{cm})\end{array}$} & $\mathrm{pH}$ (água) & $\mathrm{M} . \mathrm{O}$. & $\mathrm{P}$ & $\mathrm{K}$ & $\mathrm{Ca}$ & $\mathrm{Mg}$ & $\mathrm{Al}$ \\
\cline { 7 - 9 } \multicolumn{1}{c}{$(2: 1)$} & $\mathrm{g} \mathrm{dm}^{-3}$ & $\mathrm{mg} \mathrm{dm}^{-3}$ & \multicolumn{5}{c}{$\mathrm{mmo}_{\mathrm{c}} \mathrm{dm}^{-3}$} \\
\hline $0-5$ & 5,70 & 31,3 & 40,57 & 4,11 & 57,2 & 25,1 & 0,9 \\
$5-10$ & 5,79 & 22,2 & 30,10 & 3,91 & 47,2 & 14,6 & 0,8 \\
$10-20$ & 5,94 & 20,9 & 16,14 & 3,74 & 48,5 & 14,4 & 0,7 \\
$20-40$ & 6,16 & 15,6 & 4,47 & 2,69 & 40,2 & 12,8 & 0,1 \\
$40-60$ & 6,26 & 12,2 & 1,29 & 1,91 & 30,5 & 12,8 & 0,1 \\
\hline
\end{tabular}

Média de 5 repetições com 6 subamostras/amostra. Amostras coletadas imediatamente antes da implantação dos experimentos de soja e milho.

Tabela 5. Análise química de alguns micronutrientes da gleba 3-A, cultivado no sistema de plantio direto no período $1988 / 1996{ }^{1}$

\begin{tabular}{ccccc}
\hline $\begin{array}{c}\text { Profundidade } \\
(\mathrm{cm})\end{array}$ & $\mathrm{Cu}$ & $\mathrm{Fe}$ & $\mathrm{Mn}$ & $\mathrm{Zn}$ \\
\cline { 2 - 5 } & \multicolumn{4}{c}{$\mathrm{mg} \mathrm{dm}^{-3}$} \\
\hline $0-5$ & 2,88 & 20,65 & 73,19 & 11,68 \\
$5-10$ & 2,85 & 18,60 & 55,20 & 6,15 \\
$10-20$ & 2,75 & 17,45 & 53,30 & 4,03 \\
$20-40$ & 3,09 & 22,30 & 41,95 & 1,37 \\
$40-60$ & 3,37 & 28,15 & 30,40 & 1,13 \\
\hline
\end{tabular}

'Média de 5 repetições com 6 subamostras/amostra. Amostras coletadas imediatamente antes da implantação dos experimentos de soja e milho. 
Tabela 6. Porosidade e massa específica no perfil do solo referente à gleba em estudo, mantido sob plantio direto no período $1988-96^{1}$.

\begin{tabular}{lcccc}
\hline $\begin{array}{c}\text { Profundidade } \\
(\mathrm{cm})\end{array}$ & $\begin{array}{c}\text { Microporosidade } \\
(\%)\end{array}$ & $\begin{array}{c}\text { Macroporosidade } \\
(\%)\end{array}$ & $\begin{array}{c}\text { Porosidade } \\
\text { Total }(\%)\end{array}$ & $\begin{array}{c}\text { Massa especifica } \\
\left(\mathrm{g} \mathrm{cm}^{-3}\right)\end{array}$ \\
\hline $0-5$ & $46,83 \mathrm{a}$ & $9,34 \mathrm{~b}$ & $56,16 \mathrm{ab}$ & $1,19 \mathrm{~b}$ \\
$5-10$ & $47,54 \mathrm{a}$ & $7,22 \mathrm{~b}$ & $54,76 \mathrm{bc}$ & $1,27 \mathrm{a}$ \\
$10-20$ & $47,66 \mathrm{a}$ & $6,69 \mathrm{~b}$ & $53,35 \mathrm{a}$ & $1,27 \mathrm{a}$ \\
$20-40$ & $46,17 \mathrm{a}$ & $9,70 \mathrm{~b}$ & $54,87 \mathrm{bc}$ & $1,19 \mathrm{~b}$ \\
$40-60$ & $43,57 \mathrm{~b}$ & $15,13 \mathrm{a}$ & $57,70 \mathrm{a}$ & $1,13 \mathrm{c}$ \\
DMS & 2,03 & 3,08 & 2,10 & 0,065 \\
CV (\%) & 8,34 & 35,56 & 5,29 & 6,87 \\
\hline
\end{tabular}

Média de 4 repetiçōes e 2 amostras por repetição. Amostras coletadas imediatamente antes da implantação dos experimentos de soja e milho. Médias seguidas de letras distintas, nas colunas, diferem entre si ao nivel de significância de $\mathrm{P}=0,05$ pelo Teste de Tukey.

Ressalta-se que, antes da implantação dos experimentos com milho e soja, a área encontrava-se com vegetação espontânea composta por plantas daninhas anuais, principalmente caruru (Amaranthus hibridus), capim-colchão (Digitaria horizontalis) e trapoeraba (Commelina benghalensis), além de reduzida quantidade de restos culturais de sorgo os quais, contribuíram com 60 $\%$ de cobertura ou 3,7 tha de matéria seca. O experimento de feijão foi conduzido em área apresentando palhada proveniente de vegetação espontânea, a qual forneceu 6,7 tha de matéria seca, promovendo $90 \%$ de cobertura do solo.

A cobertura para o plantio direto foi resultante da dessecação das plantas daninhas e da palhada dos restos culturais presentes na área. 


\subsubsection{Manejo do solo}

A gleba utilizada para o experimento, apresentava-se sob o sistema de plantio direto há oito anos, sendo parte da área mobilizada em função da instalação do experimento em questão. Para tanto foram utilizados o arado de aivecas, escarificador e grade aradora.

Os implementos arado de aivecas e grade aradora foram tracionados por um trator de $80 \mathrm{hp} \mathrm{e} \mathrm{o} \mathrm{escarificador} \mathrm{foi} \mathrm{tracionado} \mathrm{por} \mathrm{um} \mathrm{trator} \mathrm{de} 118 \mathrm{hp}$, tração $4 \times 4$.

As operações de nivelamento e destorroamento mecânico do solo não foram realizadas em nenhum dos tratamentos.

\subsubsection{Aração profunda}

A aração profunda foi feita com arado de aivecas da marca lkeda (modelo MR-2R), 'com duas lâminas estriadas, com largura de corte de $40 \mathrm{~cm}$. A profundidade média de trabalho atingida foi de $30 \mathrm{~cm}$. Ressalta-se, no entanto, que o referido tratamento, teve os resíduos culturais incorporados com grade aradora antecedendo o emprego do arado

\subsubsection{Escarificação}

A escarificação foi realizada com escarificador da marca Ikeda, modelo DP-4M, com quatro hastes helicoidais de $220 \mathrm{~cm}$ de largura de trabalho, quatro discos de corte e rolo nivelador com nove lâminas fresadas. A profundidade média de trabalho atingida foi de $20 \mathrm{~cm}$. 


\subsubsection{Gradeação}

O referido tratamento constou de preparo do solo com grade aradora da marca Supertatu, modelo CR 1820, com 20 discos lisos com diâmetro de 66 $\mathrm{cm}$, atingindo profundidade média de trabalho de $14 \mathrm{~cm}$.

\subsubsection{Adubação}

Os niveis de adubação do experimento foram determinados com base na análise química do solo realizadas antes da implantação das culturas (Tabela 7).

Para a adubação nitrogenada de semeadura, utilizou-se Uréia $(45 \% \mathrm{~N})$ como fonte do elemento e na cobertura, Sulfato de Amônio ( $23 \% \mathrm{~N})$. As adubaçōes nitrogenadas foram realizadas em todos os tratamentos, exceto para a cultura da soja.

As adubações fosfatada e potássica foram efetuadas somente na semeadura, utilizando-se Superfosfato Simples $\left(20 \% \quad \mathrm{P}_{2} \mathrm{O}_{5}\right)$ e Cloreto de Potássio $\left(60 \% \mathrm{~K}_{2} \mathrm{O}\right)$ como fontes destes nutrientes, respectivamente.

Como fonte de micronutrientes utilizou-se FTE-BR 12.

Os tratamentos testemunha $(T)$ de adubação, das culturas avaliadas, caracterizaram-se pela ausência de fornecimento de fósforo e potássio.

Os tratamentos relacionados às adubações baseadas na exportação de grãos (Eg) levaram em consideração o rendimento esperado para cada cultura e as respectivas quantidades de fósforo e potássio a serem exportadas na colheita .

Para a cultura do milho utilizou-se dados de Hiroce ${ }^{1}$ et al., citados por Büll (1993); para a soja considerou-se dados de Lazarini et al. (1995) e Tanaka

\footnotetext{
${ }^{1}$ HIROCE, R.; FURLANI, A.M.C.; LIMA,M. Extração de nutrientes na colheita por populações e híbridos de milho. Campinas, IAC, 1989. 24 p. (IAC. Boletim Científico. 17).
} 
et al. (1993) e, para o feijão, dados de Cobra Neto et al. (1971) e Gallo \& Miyasaka (1961), cujas quantidades de extração são apresentadas na Tabela 8.

Tabela 7. Níveis de adubação empregados nas culturas em estudo.

\begin{tabular}{|c|c|c|c|c|c|c|}
\hline \multicolumn{2}{|c|}{ Adubação ${ }^{1}$} & \multirow{2}{*}{$\begin{array}{c}N \\
\text { semeadura }\end{array}$} & \multirow{2}{*}{$\begin{array}{c}\mathrm{N} \\
\text { cobertura }\end{array}$} & \multirow{2}{*}{$\begin{array}{l}\mathrm{P}_{2} \mathrm{O}_{5} \\
\mathrm{~kg} \mathrm{ha}^{-1}\end{array}$} & \multirow[t]{2}{*}{$\mathrm{K}_{2} \mathrm{O}$} & \multirow[t]{2}{*}{ FTE-BR 12} \\
\hline & & & & & & \\
\hline Milho & $\mathrm{T}$ & 30 & $30+90$ & 0 & 0 & 30 \\
\hline$\left(9 t h a^{-1}\right)$ & $\mathrm{Eg}$ & 30 & $30+90$ & 83 & 55 & 30 \\
\hline Soja & $\mathrm{T}$ & 0 & 0 & 0 & 0 & 30 \\
\hline$\left(3 \mathrm{tha}^{-1}\right)$ & $\mathrm{Eg}$ & 0 & 0 & 35 & 65 & 30 \\
\hline Feijão & $\mathrm{T}$ & 30 & 70 & 0 & 0 & 30 \\
\hline$\left(2,5 \mathrm{tha}^{-1}\right)$ & $\mathrm{Eg}$ & 30 & 70 & 23 & 45 & 30 \\
\hline
\end{tabular}

O rendimento médio esperado para as culturas de milho, soja e feijão foram, respectivamente, 9 t/ha, 3 tha e 2,5 t/ha.

Tabela 8. Extração de P e K por tonelada de grãos, nas culturas de milho, soja e feijão.

\begin{tabular}{lcc}
\hline $\begin{array}{l}\text { Extração } \\
(1 \text { t grão })\end{array}$ & $P$ & $K$ \\
\hline Milho & 4,0 & $\mathrm{~kg} \mathrm{ha}^{-1}$ \\
Soja & 5,0 & 5,1 \\
Feijão & 4,0 & 18,0 \\
\hline
\end{tabular}




\subsubsection{Implantação das culturas estudadas}

As culturas de milho e soja foram implantadas na safra de verão, no ano agrícola 96/97, o feijão foi semeado no inverno de 1997, com irrigação complementar, via sistema autopropelido.

Anteriormente à realização destas operações foi efetuada a aplicação do herbicida Glyphosate, na dosagem de 3,0 litros/ha, para dessecação de plantas daninhas existentes na área.

Para as operações de semeadura utilizou-se uma semeadora Semeato, modelo PAR 2800, com quatro linhas para milho, sete linhas para feijão e oito linhas para soja, provida de discos de corte de palha, sistema de bisel para adubação e disco duplo desencontrado para a distribuição das sementes.

A semeadura das culturas de milho e soja, em sistema convencional, foram realizadas após o preparo do solo, sendo a de feijão após a colheita dos experimentos do verão de 1996.

\subsubsection{Milho}

A cultura do milho foi semeada em 31 de outubro de 1996. As sementes do híbrido BR 3123 , superprecoce, foram tratadas com inseticida Thiodicarb $(0,4 \mathrm{~L} / 20 \mathrm{~kg}$ de sementes) e semeadas no espaçamento de $0,9 \mathrm{~m}$ entre linhas com 7-8 sementes/m. A parcela apresentou dimensões de $7,2 \mathrm{~m}$ de comprimento e $5,0 \mathrm{~m}$ de largura $\left(36,0 \mathrm{~m}^{2}\right)$, considerando-se como área útil as cinco linhas centrais com quatro metros de comprimento $\left(18,0 \mathrm{~m}^{2}\right)$. Aos 16 dias após a emergência foi realizado o desbaste, deixando-se $6 \mathrm{pl} / \mathrm{m}$ na linha de semeadura. 


\subsubsection{Soja}

A variedade utilizada foi FT-Estrela, com ciclo de maturação precoce, sendo semeada dia 8 de outubro de 1996. As sementes foram tratadas com $200 \mathrm{~mL}$ de Carboxin+Thiram, $250 \mathrm{ml}$ de micronutrientes (Como) e 200 gramas de inoculante contendo Bradyrhizobium japonicum, por $60 \mathrm{~kg}$ de sementes e, posteriormente, semeadas no espaçamento de $0,45 \mathrm{~m}$ entre linhas empregando-se 22 sementes por metro. A área total da parcela foi de $36,0 \mathrm{~m}^{2}$, perfazendo área útil de $21,6 \mathrm{~m}^{2}$, composta por 12 linhas centrais de 4 metros.

\subsubsection{Feijão}

A semeadura da variedade Jalo precoce foi realizada em 17 de junho de 1997, sendo as sementes tratadas com 140 gramas de Captan (750 g/kg i.a.), 70 gramas de Benomyl (500 g/kg i.a.), 1,05 kg de Carbosulfan (350 g/l i.a.) e $250 \mathrm{ml}$ de micronutrientes (Como), por $70 \mathrm{~kg}$ de sementes. O espaçamento entre linhas foi de 0,45 $\mathrm{m}$ apresentando 12-14 sementes por metro. $A$ área total da parcela foi de $15,75 \mathrm{~m}^{2}(3,15 \times 5,0 \mathrm{~m})$ e a área útil correspondente a $9,9 \mathrm{~m}^{2}$ ( 7 linhas centrais de $5 \mathrm{~m}$ de comprimento).

Durante o desenvolvimento da cultura foi utilizada a prática de irrigação desde a emergência do feijão, aplicando-se lâminas de $18 \mathrm{~mm}$ a cada 5 dias, nos manejos com revolvimento do solo e, $13,5 \mathrm{~mm}$ no plantio direto. A lâmina de irrigação foi determinada pelo uso de Tanque Classe $A$ e tensiômetro, e o balanço hídrico foi calculado através do método proposto por Thornthwaite \& Mather (1955), sendo que o uso da água foi suspenso no estádio $R_{9}$ (maturidade fisiológica da cultura). 


\subsubsection{Colheita}

As operações de colheita de milho, soja e feijão foram realizadas manualmente, coletando-se todas as plantas da área útil da parcela, sendo a umidade dos grãos corrigida para $13 \%$.

\subsection{Delineamento Experimental}

Os experimentos, em número de três, foram conduzidos em faixas no delineamento de blocos completos casualizados, com quatro tratamentos de manejo do solo e dois tratamentos de adubação, e quatro repetições (Tabela 9).

Tabela 9. Causas de variância do experimento.

\begin{tabular}{cc}
\hline Causas da Variação & GL \\
\hline Manejo do solo (M) & 3 \\
Blocos & 3 \\
Resíduo (a) & 6 \\
\hline Adubação (A) & 1 \\
Resíduo (b) & 3 \\
\hline Interação (M X A) & 3 \\
Resíduo (c) & 9 \\
\hline Total & 31 \\
\hline
\end{tabular}

Os tratamentos de manejo do solo foram constituídos de plantio direto (PD), grade aradora (GA), escarificação (ES) e aração profunda (AP). Os tratamentos de adubação foram representados pela ausência de fósforo e potássio ( $T$ ) e pelo fornecimento desses elementos fundamentado na 
exportação pelos grãos das culturas avaliadas (Eg), conforme apresentado na Tabela 10.

Os resultados foram avaliados através de análise de variância e teste de Tukey ao nivel de significância de $5 \%$ de probabilidade para a comparação de médias.

Tabela 10. Tratamentos estudados.

\begin{tabular}{ccc}
\hline Tratamento & & \\
\hline 1 & $\mathrm{PD}$ & $\mathrm{T}$ \\
& $\mathrm{Eg}$ \\
\hline 2 & $\mathrm{GA}$ & $\mathrm{T}$ \\
& & $\mathrm{Eg}$ \\
\hline 3 & $\mathrm{ES}$ & $\mathrm{T}$ \\
& & $\mathrm{Eg}$ \\
\hline 4 & $\mathrm{AP}$ & $\mathrm{T}$ \\
& & $\mathrm{Eg}$ \\
\hline
\end{tabular}

\subsection{Determinações gerais}

\subsubsection{Fertilidade do solo}

Para a determinação da fertilidade do solo, as amostras dos mesmos foram coletadas com trado, tipo rosca sem fim, nas profundidades de 0-5, 5-10, $10-20,20-40$ e 40-60 cm de profundidade, antes e depois do preparo do solo, perfazendo duas amostras compostas, constituídas de seis amostras simples, para cada parcela, nas respectivas profundidades. Após a colheita realizaram- 
se amostragens apenas no tratamento testemunha para adubação $(T)$, com uma amostra composta por parcela, constituída também de três subamostras.

As amostras foram enviadas para o laboratório do CNPAF/EMBRAPA, onde determinaram-se os teores de cálcio $(\mathrm{Ca})$, magnésio $(\mathrm{Mg})$, alumínio $(\mathrm{Al})$, fósforo $(P)$, potássio $(K)$, cobre $(\mathrm{Cu})$, zinco $(\mathrm{Zn})$, ferro $(\mathrm{Fe})$, manganês $(\mathrm{Mn})$, matéria orgânica $(\mathrm{MO})$ e a acidez $(\mathrm{pH})$.

A extração de $\mathrm{P}$ e $\mathrm{K}$ disponivel foi realizada pelo extrator Mehlich 1 , 0 teor de $\mathrm{P}$ foi determinado por Colorimetria e o de $\mathrm{K}$ pelo método fotométrico. Os elementos $\mathrm{Ca}, \mathrm{Mg}$ e Al foram extraídos em $\mathrm{KCl} 1 \mathrm{~N}$, os teores de $\mathrm{Ca}$ e $\mathrm{Mg}$ foram determinados por titulação com EDTA $0,01 \mathrm{~N}$ e os de Al com $\mathrm{NaOH} 0,01 \mathrm{~N}$ (EMBRAPA, 1997).

Os metais $\mathrm{Zn}, \mathrm{Fe}, \mathrm{Mn}$ e $\mathrm{Cu}$ foram extraídos pelo extrator Mehlich 1 e determinados por espectrofotometria de absorção atômica.

A matéria orgânica foi determinada pelo método proposto por Walkley \& Black (1934).

\subsubsection{Parâmetros físicos do solo}

As amostras para determinação dos parâmetros físicos foram coletadas somente nos tratamentos Eg para adubação, em todos os tratamentos de manejo.

Para avaliação da massa específica e porosidade foram coletadas amostragens nas profundidades de $0-5,5-10,10-20,20-40$ e $40-60 \mathrm{~cm}$ utilizando-se anéis volumétricos de $98,17 \mathrm{~cm}^{3}$ de volume, seguindo a metodologia proposta pela EMBRAPA (1997).

A massa específica do solo foi determinada pelo método do anel volumétrico, onde as amostras foram secas em estufa, por 24 a 48 horas, e em 
seguida, pesadas; calculando-se a razão entre a massa da amostra seca e o volume do anel.

A microporosidade foi determinada pelo método da mesa de tensão a 60 $\mathrm{cm}$ de altura, em amostras indeformadas, e correspondeu ao volume de água retido na tensão de $6 \mathrm{kPa}$.

A porosidade total foi calculada pelo índice de saturação (IS), considerando-se a massa da amostra seca e saturada, correspondendo ao indice de saturação.

A macroporosidade foi determinada pela diferença entre a porosidade total e a microporosidade.

\subsubsection{Custos de produção}

A análise econômica e a determinação da relação benefício/custo dos sistemas foram efetuadas mediante metodologia proposta por Neves \& Shirota (1985) .

Os custos de produção foram obtidos mantendo-se fixos todos os fatores de produção, exceto o de preparo do solo, adubações, manejo de plantas daninhas e irrigação que variaram em função dos implementos utilizados, do número de hora-máquina, das diferentes doses de fertilizantes e herbicidas utilizados e da quantidade de água aplicada.

Para se compor os custos utilizou-se dos coeficientes técnicos da fazenda para as operações de preparo do solo, semeadura, pulverizações e colheita, incluindo mão-de-obra.

Os custos das operações e insumos e a receita líquida foram calculados em dólar por hectare (US\$/ha), equivalente ao mês de dezembro de 1998, cotado a $R \$ 1,205$. Os valores finais dos custo foram apresentados também em sacas de $60 \mathrm{~kg}$ de produto. 
Para o cálculo da relação benefício/custo considerou-se o preço recebido pelos produtos (grãos) nos meses de colheita e os rendimentos obtidos em cada sistema de produção. Os preços de venda do milho e feijão foram estimados pelo valor médio recebido pelo produtor de Goiás no período de colheita, em fevereiro de 1997 para o milho, US\$4,80 (R\$ 5,79) por saca de $60 \mathrm{~kg}$, e em setembro de 1997 para o feijão, US\$27,70 (R\$33,38) por saco de $60 \mathrm{~kg}$. O preço de venda da soja foi obtido pelo valor médio recebido no período de colheita de janeiro/fevereiro de 1997, US\$11,86 (R\$14,29) por saca de $60 \mathrm{~kg}$.

Os estudos de rentabilidade foram utilizados para permitir a análise comparativa entre os diferentes sistemas de manejos estudados. 


\section{RESULTADOS E DISCUSSÃO}

\subsection{Fertilidade do solo}

Os resultados referentes aos teores de nutrientes presentes no solo e a distribuição dos mesmos no perfil para as culturas de milho, soja e feijão foram avaliados após a colheita das mesmas e são apresentados nas Tabelas 11 a 16.

A avaliação dos resultados evidenciou para a maioria dos nutrientes, elevado coeficiente de variação (CV), indicando grande variabilidade espacial dos dados coletados.

Para a cultura do milho, constatou-se a não ocorrência de efeito significativo dos diferentes tipos de manejos de solo em relação ao teor médio dos nutrientes, com exceção do elemento cobre e da matéria orgânica (Tabelas 11 e 12). $\mathrm{O}$ teor de $\mathrm{Cu}$ foi maior no tipo de manejo $\mathrm{ES}$ e menor no manejo AP, mas a similaridade dos valores mostra que pode ter havido problemas na amostragem. Já a matéria orgânica teve maiores teores no tratamento AP o que pode ter sido causado pela maior decomposição do material vegetal devido ao revolvimento do solo, sendo esta situação temporária, ou seja, há a tendência de redução nos teores de matéria orgânica nos solos mobilizados.

A distribuição dos nutrientes no perfil foi significativa ao nivel de $5 \%$ de probabilidade (teste de Tukey), exceto para o Al. O pH foi mais baixo na superfície provavelmente devido ao efeito acidificante dos adubos nitrogenados. Resultados semelhantes foram obtidos por Muzilli (1983), 
Centurion et al. (1985), Merten \& Mielniczuk (1992) e Blevins et al. (1983). Já Anghinoni \& Saler (1995) concluíram que, devido a mineralização mais lenta da matéria orgânica sob plantio direto e o teor de água, ocorre diluição da concentração dos ácidos orgânicos elevando assim o pH.

Tabela 11. Efeito do manejo de solo sobre a distribuição de $\mathrm{P}, \mathrm{Ca}, \mathrm{Mg}, \mathrm{K}, \mathrm{Al}$, $\mathrm{pH}$ e matéria orgânica no perfil de solo da gleba 3-A, após a colheita do milho.

\begin{tabular}{|c|c|c|c|c|c|c|c|c|}
\hline \multirow{3}{*}{\multicolumn{2}{|c|}{$\begin{array}{c}\text { Manejo } \\
\text { Prof. }(\mathrm{cm})^{2} \\
\text { PD } \quad 0.5\end{array}$}} & \multirow{2}{*}{$\mathrm{pH}$ (água) } & \multirow{2}{*}{$\frac{\mathrm{MO}}{\mathrm{g} \mathrm{dm^{-3 }}}$} & \multirow{2}{*}{$\frac{P}{\mathrm{mg} \mathrm{dm}^{-3}}$} & $\mathrm{Ca}$ & $\mathrm{Mg}$ & $\mathrm{K}$ & $\mathrm{Al}$ \\
\hline & & & & & \multicolumn{4}{|c|}{$\mathrm{mmol}_{\mathrm{c}} \mathrm{dm}^{-3}$} \\
\hline \multirow[t]{6}{*}{$\overline{P D}$} & & 5,47 & 30,2 & $45, \infty$ & $53,2 a$ & 19,7 & 3,95 & 0,7 \\
\hline & $5-10$ & 5,70 & 19,0 & 23,35 & $43,7 b$ & 15,2 & 4,61 & 0,5 \\
\hline & $10-20$ & 5,95 & 13,7 & 9,92 & $42,2 \mathrm{~b}$ & 13,2 & 4,40 & 0,2 \\
\hline & $20-40$ & 6,22 & 10,5 & 1,82 & $33,5 \mathrm{c}$ & 9,5 & 3,74 & 0,0 \\
\hline & $40-60$ & 6,42 & 14,2 & 0,72 & $27,0 \mathrm{c}$ & 11,7 & 2,86 & 0,0 \\
\hline & & $5,95 \mathrm{~A}$ & $17,5 \mathrm{AB}$ & $16,16 \mathrm{~A}$ & $39,9 \mathrm{~A}$ & $13,9 \mathrm{~A}$ & $3,91 \mathrm{~A}$ & $0,3 \mathrm{~A}$ \\
\hline \multirow[t]{6}{*}{ GA } & 0.5 & 5,50 & 27,7 & 40,55 & $48,7 a$ & 17,7 & 3,85 & 1,0 \\
\hline & $5-10$ & 5,77 & 17,5 & 32,20 & $45,2 \mathrm{ab}$ & 15,7 & 3,63 & 0,7 \\
\hline & $10-20$ & 5,92 & 13,0 & 9,60 & $39,0 \mathrm{~b}$ & 12,0 & 3,29 & 0,5 \\
\hline & $20-40$ & 6,15 & $\infty, 7$ & 1,90 & $30,7 \mathrm{c}$ & 9,0 & 2,42 & 0,5 \\
\hline & $40-60$ & 6,25 & $\infty 9,7$ & 0,85 & $25,0 \mathrm{c}$ & 9,7 & 2,08 & 0,2 \\
\hline & & $5,92 \mathrm{~A}$ & $15,5 \mathrm{~B}$ & $17,02 \mathrm{~A}$ & $37,7 \mathrm{~A}$ & $12,8 \mathrm{~A}$ & $3,06 \mathrm{~A}$ & $0,6 \mathrm{~A}$ \\
\hline \multirow[t]{6}{*}{ ES } & 0.5 & 5,47 & 25,5 & 40,12 & $49,7 a$ & 22,2 & 3,74 & 1,0 \\
\hline & $5-10$ & 5,70 & 20,2 & 24,85 & $42,5 a b$ & 14,7 & 3,30 & 1,5 \\
\hline & $10-20$ & 5,85 & 15,2 & 13,15 & $40,0 \mathrm{~b}$ & 12,5 & 3,19 & 1,7 \\
\hline & $20-40$ & 6,12 & 12,2 & 3,20 & $36,2 \mathrm{~b}$ & 11,0 & 2,86 & 0,5 \\
\hline & $40-60$ & 6,35 & 15,5 & 1,25 & $31,0 \mathrm{C}$ & 9,0 & 2,41 & 0,5 \\
\hline & & $5,90 \mathrm{~A}$ & $17,7 \mathrm{AB}$ & $16,51 \mathrm{~A}$ & $39,9 \mathrm{~A}$ & $13,9 \mathrm{~A}$ & $3,12 \mathrm{~A}$ & $1,0 \mathrm{~A}$ \\
\hline \multirow[t]{6}{*}{ AP } & 0.5 & $5, \infty$ & 23.7 & 38,45 & $45,2 \mathrm{a}$ & 15,2 & 3,62 & 1,0 \\
\hline & $5-10$ & 5,67 & 25,0 & 39,87 & $49,7 \mathrm{a}$ & 17,0 & 2,85 & 1,0 \\
\hline & $10-20$ & 5,80 & 20,0 & 25,30 & $50,5 a$ & 15,2 & 3,51 & 1,0 \\
\hline & $20-40$ & 6,02 & 16,7 & 9,67 & $46,2 \mathrm{a}$ & 15,5 & 2,73 & 1,0 \\
\hline & $40-60$ & 6,20 & 20,2 & 1,90 & $33,2 \mathrm{~b}$ & 12,5 & 1,66 & 1,0 \\
\hline & & $5,86 \mathrm{~A}$ & $21,1 \mathrm{~A}$ & $23,04 \mathrm{~A}$ & $45,0 \mathrm{~A}$ & $15,1 \mathrm{~A}$ & $2,89 \mathrm{~A}$ & $1,0 \mathrm{~A}$ \\
\hline \multicolumn{2}{|c|}{ DMS (média) } & 0,31 & 4,52 & 0,29 & 7,4 & 5,0 & 1,34 & 1,2 \\
\hline \multirow{2}{*}{\multicolumn{2}{|c|}{$\begin{array}{l}\text { DMS (prof.) } \\
\text { CV (\%) }\end{array}$}} & - & - & - & 8,0 & - & - & - \\
\hline & & 5,28 & 21,42 & 40,59 & 18,41 & 36,53 & 42,08 & 159,88 \\
\hline \multicolumn{9}{|c|}{ Prof. $(\mathrm{cm})$} \\
\hline \multirow{2}{*}{\multicolumn{2}{|c|}{$\begin{array}{l}0-5 \\
5-10\end{array}$}} & $5,51 \mathrm{E}$ & $26,8 \mathrm{~A}$ & $41,03 \mathrm{~A}$ & $49,2 \mathrm{~A}$ & $18,7 \mathrm{~A}$ & $3,79 \mathrm{~A}$ & $0,9 \mathrm{~A}$ \\
\hline & & $5,71 \mathrm{D}$ & $20,4 \mathrm{~B}$ & $30,07 \mathrm{~B}$ & $45,3 \mathrm{AB}$ & $15,7 \mathrm{AB}$ & $3,61 \mathrm{~A}$ & $0,9 \mathrm{~A}$ \\
\hline \multicolumn{2}{|c|}{$10-20$} & $5,88 \mathrm{C}$ & $15,5 \mathrm{C}$ & $14,49 \mathrm{C}$ & $42,9 \mathrm{~B}$ & $13,2 \mathrm{BC}$ & $3,60 \mathrm{~A}$ & $0,9 \mathrm{~A}$ \\
\hline \multicolumn{2}{|c|}{$20-40$} & $6,13 \mathrm{~B}$ & $14,9 \mathrm{C}$ & $4,15 \mathrm{D}$ & $36,7 \mathrm{C}$ & $11,2 \mathrm{C}$ & $2,96 \mathrm{~B}$ & $0,5 \mathrm{~A}$ \\
\hline \multicolumn{2}{|c|}{$40-60$} & $6,31 \mathrm{~A}$ & $12,3 \mathrm{C}$ & $1,18 \mathrm{D}$ & $29,1 \mathrm{D}$ & $10,7 \mathrm{C}$ & $2,26 \mathrm{C}$ & $0,4 \mathrm{~A}$ \\
\hline \multirow{2}{*}{\multicolumn{2}{|c|}{$\begin{array}{l}\text { DMS } \\
\text { CV (\%) }\end{array}$}} & 0,11 & 4,16 & 6,64 & 4,0 & 3,2 & 0,48 & 7,0 \\
\hline & & 2,35 & 30,34 & 49,56 & 19,13 & 31,30 & 19,44 & 80,93 \\
\hline \multicolumn{2}{|c|}{ Man. x prof. } & ns & ns & ns & $\star \star$ & ns & ns & ns \\
\hline
\end{tabular}


Tabela 12. Efeito do manejo de solo sobre a distribuição de $\mathrm{Cu}, \mathrm{Fe}, \mathrm{Mn}$ e $\mathrm{Zn}$ no perfil de solo da gleba 3-A, após a colheita do milho.

\begin{tabular}{|c|c|c|c|c|c|}
\hline & Manejo & $\mathrm{Cu}$ & $\mathrm{Fe}$ & $\mathrm{Mn}$ & $\mathrm{Zn}$ \\
\hline & Prof. $(\mathrm{cm})^{2}$ & \multicolumn{4}{|c|}{$\mathrm{mg} \mathrm{dm}^{-3}$} \\
\hline \multirow[t]{6}{*}{$\mathrm{PD}$} & $0-5$ & $3,00 \mathrm{~b}$ & 20,00 & $90,25 \mathrm{a}$ & 12,07 \\
\hline & $5-10$ & $2,92 \mathrm{~b}$ & $17, \infty$ & $47,50 \mathrm{~b}$ & 6,25 \\
\hline & $10-20$ & $3,15 b$ & 18,25 & $53,75 b$ & 4,17 \\
\hline & $20-40$ & $3,55 a b$ & 24,00 & 36,25 bc & 1,15 \\
\hline & $40-60$ & $3,95 \mathrm{a}$ & 29,75 & $26,25 \mathrm{c}$ & 0,67 \\
\hline & & $3,31 \mathrm{AB}$ & $21,80 \mathrm{~A}$ & $50,80 \mathrm{~A}$ & $4,86 \mathrm{~A}$ \\
\hline \multirow[t]{5}{*}{ GA } & 0.5 & $3,15 b$ & 18,75 & 54,75 a & 9,02 \\
\hline & $5-10$ & $3,02 \mathrm{~b}$ & $17, \infty$ & $46, \infty$ ab & 6,47 \\
\hline & $\begin{array}{l}10-20 \\
20-40\end{array}$ & $\begin{array}{l}3,15 b \\
357 a b\end{array}$ & $\begin{array}{l}18,75 \\
23,25\end{array}$ & $\begin{array}{l}38,75 a b \\
28,00 b\end{array}$ & $\begin{array}{l}3,02 \\
1,27\end{array}$ \\
\hline & $40-\infty 0$ & $3,75 \mathrm{a}$ & 29,25 & $25,25 b$ & 0,75 \\
\hline & & $3,33 \mathrm{AB}$ & $21,40 \mathrm{~A}$ & $38,55 \mathrm{~A}$ & $4,11 \mathrm{~A}$ \\
\hline \multirow[t]{6}{*}{ ES } & 0.5 & $3,40 \mathrm{ab}$ & 18,75 & $62,25 a$ & 14,57 \\
\hline & $5-10$ & $3,35 a b$ & 16,50 & $43,75 a b$ & 11,40 \\
\hline & $10-20$ & $3,15 \mathrm{~b}$ & 17,25 & $45,50 \mathrm{ab}$ & 7,40 \\
\hline & $20-40$ & $3,55 a b$ & $22, \infty$ & $37,25 \mathrm{~b}$ & 2,80 \\
\hline & $40-60$ & $3,87 a$ & 28,50 & $31,75 \mathrm{~b}$ & 1,62 \\
\hline & & $3,46 \mathrm{~A}$ & $20,60 \mathrm{~A}$ & $44,10 \mathrm{~A}$ & $7,56 \mathrm{~A}$ \\
\hline \multirow[t]{6}{*}{ AP } & $0-5$ & $3,07 a b$ & $19, \infty$ & $50,75 a$ & 10,32 \\
\hline & $5-10$ & $2,87 \mathrm{~b}$ & 17,25 & 56,00 a & 9,80 \\
\hline & $10-20$ & $2,60 \mathrm{~b}$ & 15,75 & $51,75 a$ & 6.60 \\
\hline & $20-40$ & $2,65 b$ & 16,50 & $46,00 a$ & 2,60 \\
\hline & $40-60$ & $3,47 \mathrm{a}$ & 25,25 & $35,25 a$ & 1,35 \\
\hline & & $2,93 \mathrm{~B}$ & $18,75 \mathrm{~A}$ & $47,95 \mathrm{~A}$ & $6,13 \mathrm{~A}$ \\
\hline \multirow{3}{*}{\multicolumn{2}{|c|}{$\begin{array}{l}\text { DMS (média) } \\
\text { DMS (prof.) } \\
\text { CV }(\%)\end{array}$}} & 0,46 & 4,48 & 21,70 & 4,11 \\
\hline & & 0,53 & - & 21,89 & - \\
\hline & & 14,25 & 21,97 & 48,46 & 73,50 \\
\hline \multicolumn{6}{|c|}{ Prof. $(\mathrm{cm})$} \\
\hline \multirow{7}{*}{\multicolumn{2}{|c|}{$\begin{array}{l}0-5 \\
5-10 \\
10-20 \\
20-40 \\
40-60 \\
\text { DMS } \\
\text { CV }(\%)\end{array}$}} & $3,16 \mathrm{BC}$ & $19,12 \mathrm{BC}$ & $64,50 \mathrm{~A}$ & $11,50 \mathrm{~A}$ \\
\hline & & $3,04 \mathrm{C}$ & $16,93 \mathrm{C}$ & $48,31 \mathrm{~B}$ & $8,48 \mathrm{~B}$ \\
\hline & & $3,01 \mathrm{C}$ & $17,50 \mathrm{C}$ & $47,44 \mathrm{BC}$ & $5,30 \mathrm{C}$ \\
\hline & & $3,33 \mathrm{~B}$ & $21,44 \mathrm{~B}$ & $36,87 \mathrm{CD}$ & $1,95 \mathrm{D}$ \\
\hline & & $3,76 \mathrm{~A}$ & $28,19 \mathrm{~A}$ & $29,62 \mathrm{D}$ & $1,10 \mathrm{D}$ \\
\hline & & 0,27 & 2,64 & 10,95 & 2,68 \\
\hline & & 15,55 & 14,26 & 39,93 & 42,77 \\
\hline \multicolumn{2}{|c|}{ Man. $x$ prof. } & * & ns & $\star *$ & ns \\
\hline
\end{tabular}

A interação manejo-profundidade foi significativa ao nivel $5 \%$ de probabilidade (teste de Tukey) para os elementos $\mathrm{Ca}$, $\mathrm{Cu}$ e $\mathrm{Mn}$, porém houve grande variabilidade no teor dos nutrientes no solo. Parra (1986) relata que o manejo diferenciado do solo nem sempre apresenta resultados coerentes 
quanto à distribuição de nutrientes no perfil. Ou seja, para estes elementos, o manejo do solo interferiu na distribuição dos nutrientes ao longo do perfil, com tendência de acúmulo na superfície para cálcio em todos os manejos, ocorrendo o inverso com o cobre e, no caso do manganês, a tendência foi de menores teores na superfície.

Ressalta-se aqui a importância da distribuição do cálcio no perfil para possibilitar 0 crescimento radicular, como ressaltado por Favarin \& Fancelli (1989).

$\mathrm{Na}$ cultura da soja, os niveis dos nutrientes $\mathrm{Ca}$ e $\mathrm{Cu}$ foram afetados significativamente pelo manejo do solo. Os teores de Ca foram menores no tipo de manejo AP e maiores $\mathrm{PD}$. O teor de $\mathrm{Cu}$ foi maior nos tratamentos $\mathrm{ES}, \mathrm{AP}$ e GA e menor no manejo PD. A distribuição dos nutrientes no perfil foi significativa, exceto para o alumínio (Tabelas 13 e 14).

A disponibilidade maior do cobre nos tratamentos com mobilização do solo pode ser devido ao menor $\mathrm{pH}$ ou ao menor teor de matéria orgânica, reduzindo a complexação do mesmo, conforme também relatado por Motta \& Prevedello (1995).

A interação manejo-profundidade foi significativa ao nivel de $5 \%$ de probabilidade (teste de Tukey) para os elementos $\mathrm{Mg}, \mathrm{K}$ e $\mathrm{Zn}$. O magnésio concentrou-se nos primeiros $5 \mathrm{~cm}$ de profundidade em todos os manejos, exceto no tratamento AP, onde este se distribuiu mais uniformemente ao longo do perfil. O potássio apresentou tendência de acúmulo na superfície, conforme também ocorrido com o zinco.

$\mathrm{Na}$ cultura do feijão não houve efeito significativo do manejo no teor dos nutrientes (Tabelas 15 e 16). A distribuição dos nutrientes no perfil do solo foi significativa ao nivel de $5 \%$ de probabilidade.

Não houve efeito significativo do manejo na distribuição dos nutrientes no perfil. 
Porém, de maneira geral, em todos os tratamentos estudados, constatou-se a tendência de acúmulo de cálcio, magnésio e fósforo no perfil superficial do solo. O mesmo foi constatado por Lal (1976) e Muzilli (1986).

Tabela 13. Efeito do manejo de solo sobre a distribuição de $\mathrm{P}, \mathrm{Ca}, \mathrm{Mg}, \mathrm{K}, \mathrm{Al}, \mathrm{pH}$ e matéria orgânica no perfil de solo da gleba 3-A, após a colheita da soja.

\begin{tabular}{|c|c|c|c|c|c|c|c|c|}
\hline \multirow{2}{*}{\multicolumn{2}{|c|}{$\frac{\text { Manejo }}{\text { Prof. }(\mathrm{cm})^{2}}$}} & \multirow[t]{2}{*}{$\mathrm{pH}$ (água) } & \multirow{2}{*}{$\frac{\mathrm{MO}}{\mathrm{gdm^{-3 }}}$} & \multirow{2}{*}{$\frac{P}{m g d m^{-3}}$} & $\mathrm{Ca}$ & $\mathrm{Mg}$ & $\mathrm{K}$ & $\mathrm{Al}$ \\
\hline & & & & & \multicolumn{4}{|c|}{$\mathrm{mmol}_{\mathrm{c}} \mathrm{dm}^{-3}$} \\
\hline \multirow[t]{5}{*}{ PD } & $0-5$ & 5,82 & 31,2 & 34,20 & 60,5 & $24,5 \mathrm{a}$ & $3,53 a$ & 1,0 \\
\hline & $5-10$ & 5,92 & 33,5 & 28,17 & 48,0 & $14,2 b$ & $3,52 a$ & 1,0 \\
\hline & $10-20$ & 6,10 & 22,2 & 16,65 & 52,7 & $14,2 \mathrm{~b}$ & $3,96 \mathrm{a}$ & 1,0 \\
\hline & $20-40$ & 6,27 & 17,2 & 5,22 & 43,7 & $8,5 \mathrm{c}$ & $2,66 a b$ & 0,5 \\
\hline & $40-60$ & $\begin{array}{c}6,30 \\
6,08 \mathrm{~A}\end{array}$ & $\begin{array}{c}12,5 \\
213 \mathrm{~A}\end{array}$ & $\begin{array}{c}1,35 \\
17,12 \mathrm{~A}\end{array}$ & $\begin{array}{c}33,0 \\
47,6 \mathrm{~A}\end{array}$ & $\begin{array}{c}9,0 \mathrm{c} \\
14.1 \mathrm{~A}\end{array}$ & $\begin{array}{l}1,89 \mathrm{~b} \\
312 \mathrm{~A}\end{array}$ & 0,5 \\
\hline \multirow[t]{6}{*}{ GA } & 0.5 & 5,97 & 30,5 & 41,65 & 53,2 & $23,5 \mathrm{a}$ & $5,05 \mathrm{a}$ & 0,7 \\
\hline & $5-10$ & 5,90 & 24,7 & 27,12 & 43,2 & $13,5 b$ & $4,13 \mathrm{ab}$ & 1,0 \\
\hline & $10-20$ & 6,02 & 23,5 & 17,15 & 49,0 & $12,0 \mathrm{~b}$ & $3,62 \mathrm{~b}$ & 1.0 \\
\hline & $20-40$ & 6,17 & 18,2 & 7,65 & 41,5 & $13,5 \mathrm{~b}$ & $2,23 \mathrm{c}$ & 1,0 \\
\hline & $40-60$ & 6,40 & 13,2 & 3,32 & 31,2 & $11,7 \mathrm{~b}$ & $1,60 \mathrm{c}$ & 1,0 \\
\hline & & $6,09 \mathrm{~A}$ & $22,0 \mathrm{~A}$ & $19,38 \mathrm{~A}$ & $43,6 \mathrm{AB}$ & $14,8 \mathrm{~A}$ & $3,33 \mathrm{~A}$ & $0,9 \mathrm{~A}$ \\
\hline \multirow[t]{6}{*}{ ES } & 0.5 & 5,95 & 31,0 & 38,50 & 56,0 & $22,2 \mathrm{a}$ & $5,61 \mathrm{a}$ & 1,0 \\
\hline & $5-10$ & 5,77 & 24,7 & 34,90 & 43,2 & $137 \mathrm{~b}$ & $4,18 \mathrm{~b}$ & 1,0 \\
\hline & $10-20$ & 6,10 & 17,7 & 19,45 & 48,0 & $12,5 \mathrm{~b}$ & $3,41 \mathrm{bc}$ & 1,0 \\
\hline & $20-40$ & 6,25 & 17,7 & 8,55 & 41,2 & $12,5 \mathrm{~b}$ & $3,07 \mathrm{bc}$ & 1,0 \\
\hline & $40-60$ & 6,30 & 13,5 & 2,47 & 29,2 & $10,7 \mathrm{~b}$ & $2,13 \mathrm{c}$ & 0,7 \\
\hline & & $6,07 \mathrm{~A}$ & $21,8 \mathrm{~A}$ & $20,77 \mathrm{~A}$ & $43,5 \mathrm{AB}$ & $14,3 \mathrm{~A}$ & $3,68 \mathrm{~A}$ & $0,9 \mathrm{~A}$ \\
\hline \multirow[t]{6}{*}{ AP } & 0.5 & 6,00 & 24,5 & 34,30 & 43,2 & $15,0 \mathrm{a}$ & $4,80 \mathrm{a}$ & 1,0 \\
\hline & $5-10$ & 5,92 & 23,7 & 29,15 & 41,5 & $16,2 a b$ & $3,74 a b$ & 1,0 \\
\hline & $10-20$ & 6,07 & 20,2 & 17,72 & 40,2 & $13,2 a b$ & $3,03 \mathrm{~b}$ & 1,0 \\
\hline & $20-40$ & 6,20 & 17,5 & 9,25 & 36,0 & $11,7 \mathrm{~b}$ & $2,77 b$ & 1,0 \\
\hline & $40-60$ & 6,37 & 13,7 & 3,55 & 32,0 & $11,2 \mathrm{~b}$ & $2,25 \mathrm{~b}$ & 1,0 \\
\hline & & $6,11 \mathrm{~A}$ & $19,9 \mathrm{~A}$ & $18,79 \mathrm{~A}$ & $38,6 \mathrm{~B}$ & $13,5 \mathrm{~A}$ & $3,32 \mathrm{~A}$ & $1,0 \mathrm{~A}$ \\
\hline \multicolumn{2}{|c|}{ DMS (média) } & 0,164 & 3,07 & 13,867 & 8,86 & 2,64 & 1,38 & 0,26 \\
\hline \multicolumn{2}{|c|}{ DMS (prof.) } & - & - & - & - & 4,2 & 1,30 & - \\
\hline \multicolumn{2}{|c|}{ CV $(\%)$} & 2,73 & 14,21 & 73,86 & 20,69 & 18,87 & 41,58 & 29,05 \\
\hline \multicolumn{9}{|c|}{ Prof. (cm) } \\
\hline \multicolumn{2}{|c|}{$0-5$} & $5,94 \mathrm{D}$ & $29,3 \mathrm{~A}$ & $37,16 \mathrm{~A}$ & $53,2 \mathrm{~A}$ & $21,3 \mathrm{~A}$ & $4,75 \mathrm{~A}$ & $0,9 \mathrm{~A}$ \\
\hline \multirow{2}{*}{\multicolumn{2}{|c|}{$\begin{array}{l}5-10 \\
10-20\end{array}$}} & $5,88 \mathrm{D}$ & $24,2 \mathrm{~B}$ & $29,84 \mathrm{~B}$ & $44,0 \mathrm{BC}$ & $14,4 \mathrm{~B}$ & $3,89 \mathrm{~B}$ & $1,0 \mathrm{~A}$ \\
\hline & & $6,07 \mathrm{C}$ & $22,0 \mathrm{~B}$ & $17,74 \mathrm{C}$ & $47,5 \mathrm{~B}$ & $13,0 \mathrm{BC}$ & $3,50 \mathrm{~B}$ & $1,0 \mathrm{~A}$ \\
\hline \multicolumn{2}{|c|}{$20-40$} & $6,22 \mathrm{~B}$ & $17,7 \mathrm{C}$ & $7,67 \mathrm{D}$ & $40,6 \mathrm{C}$ & $11,6 \mathrm{CD}$ & $2,68 \mathrm{C}$ & $0,9 \mathrm{~A}$ \\
\hline \multicolumn{2}{|c|}{$40-60$} & $6,34 \mathrm{~A}$ & $13,2 \mathrm{D}$ & $2,67 \mathrm{D}$ & $31,4 \mathrm{D}$ & $10,7 D$ & $1,97 \mathrm{D}$ & $0,8 \mathrm{~A}$ \\
\hline \multicolumn{2}{|c|}{ DMS } & 0,110 & 2,19 & 5,633 & 5,40 & 2,13 & 0,65 & 0,22 \\
\hline \multicolumn{2}{|c|}{$\mathrm{CV}(\%)$} & 1,80 & 10,28 & 29,56 & 12,42 & 15,00 & 19,28 & 24,17 \\
\hline \multicolumn{2}{|c|}{ Man. x prof. } & ns & ns & ns & ns & ** & * & ns \\
\hline
\end{tabular}


Tabela 14. Efeito do manejo de solo sobre a distribuição de $\mathrm{Cu}, \mathrm{Fe}, \mathrm{Mn}$ e $\mathrm{Zn}$ no perfil de solo da gleba 3-A, após a colheita da soja.

\begin{tabular}{|c|c|c|c|c|c|}
\hline & Manejo & $\mathrm{Cu}$ & $\mathrm{Fe}$ & $\mathrm{Mn}$ & $\mathrm{Zn}$ \\
\hline & Prof. $(\mathrm{cm})^{2}$ & \multicolumn{4}{|c|}{$\mathrm{mg} \mathrm{dm}^{-3}$} \\
\hline$\overline{P D}$ & $\begin{array}{l}0-5 \\
5-10 \\
10-20 \\
20-40 \\
40-60\end{array}$ & $\begin{array}{c}2,90 \\
2,62 \\
2,22 \\
2,55 \\
3,05 \\
2,67 \mathrm{~B}\end{array}$ & $\begin{array}{c}18,25 \\
17,00 \\
16,00 \\
18,00 \\
22,25 \\
18,30 \mathrm{~A}\end{array}$ & $\begin{array}{c}92,00 \\
54,00 \\
49,75 \\
33,25 \\
27,25 \\
51,25 \mathrm{~A}\end{array}$ & $\begin{array}{c}12,20 \mathrm{a} \\
5,02 \mathrm{~b} \\
3,22 \mathrm{bc} \\
1,25 \mathrm{c} \\
1,10 \mathrm{c} \\
4,56 \mathrm{~A}\end{array}$ \\
\hline GA & $\begin{array}{l}0-5 \\
5-10 \\
10-20 \\
20-40 \\
40-60\end{array}$ & $\begin{array}{c}3,32 \\
2,77 \\
2,52 \\
2,85 \\
3,25 \\
2,96 \mathrm{AB}\end{array}$ & $\begin{array}{c}18,25 \\
16,25 \\
14,75 \\
18,00 \\
23,25 \\
18,10 \mathrm{~A}\end{array}$ & $\begin{array}{c}87,25 \\
57,75 \\
50,25 \\
41,00 \\
30,50 \\
53,35 \mathrm{~A}\end{array}$ & $\begin{array}{c}11,82 \mathrm{a} \\
5,90 \mathrm{~b} \\
4,17 \mathrm{~b} \\
1,92 \mathrm{c} \\
1,17 \mathrm{c} \\
5,00 \mathrm{~A}\end{array}$ \\
\hline ES & $\begin{array}{l}0-5 \\
5-10 \\
10-20 \\
20-40 \\
40-60\end{array}$ & $\begin{array}{c}3,20 \\
3,27 \\
2,80 \\
3,17 \\
3,82 \\
3,25 \mathrm{~A}\end{array}$ & $\begin{array}{c}19,00 \\
18, \infty 0 \\
16,75 \\
19, \infty 0 \\
24,50 \\
19,45 \text { A }\end{array}$ & $\begin{array}{c}72,50 \\
53,25 \\
52,00 \\
44,00 \\
32,75 \\
50,90 \mathrm{~A}\end{array}$ & $\begin{array}{l}10,90 \mathrm{a} \\
7,57 \mathrm{~b} \\
4,17 \mathrm{c} \\
1,95 \mathrm{~d} \\
1,27 \mathrm{~d} \\
5,17 \mathrm{~A}\end{array}$ \\
\hline AP & $\begin{array}{l}0-5 \\
5-10 \\
10-20 \\
20-40 \\
40-60\end{array}$ & $\begin{array}{c}3,07 \\
3,10 \\
2,97 \\
3,05 \\
3,62 \\
3,16 \mathrm{AB}\end{array}$ & $\begin{array}{c}22,50 \\
20,50 \\
20,00 \\
22,25 \\
26,25 \\
22,30 \mathrm{~A}\end{array}$ & $\begin{array}{c}64,50 \\
67,00 \\
61,25 \\
40,75 \\
40,25 \\
54,75 \mathrm{~A}\end{array}$ & $\begin{array}{c}7,50 \mathrm{a} \\
7,30 \mathrm{ab} \\
4,52 \mathrm{~b} \\
2,05 \mathrm{bc} \\
1,35 \mathrm{c} \\
4,54 \mathrm{~A}\end{array}$ \\
\hline & $\begin{array}{l}\text { (média) } \\
\text { (prof.) } \\
\% \text { ) }\end{array}$ & $\begin{array}{c}0,496 \\
- \\
16,67 \\
\end{array}$ & $\begin{array}{c}6,542 \\
- \\
33,92 \\
\end{array}$ & $\begin{array}{c}7,087 \\
- \\
13,66 \\
\end{array}$ & $\begin{array}{c}2,095 \\
2,84 \\
44,02 \\
\end{array}$ \\
\hline $\begin{array}{l}\mathrm{Pr} \\
0-5 \\
5-1 \\
10 \\
20 \\
40 \\
\mathrm{DI} \\
\mathrm{CI}\end{array}$ & $\begin{array}{l}0 \\
0 \\
0 \\
6 \\
\%)\end{array}$ & $\begin{array}{c}3,12 \mathrm{AB} \\
2,94 \mathrm{BC} \\
2,63 \mathrm{C} \\
2,90 \mathrm{BC} \\
3,46 \mathrm{~A} \\
0,358 \\
11,86\end{array}$ & $\begin{array}{c}19,50 \mathrm{~B} \\
17,94 \mathrm{~B} \\
16,87 \mathrm{~B} \\
19,31 \mathrm{~B} \\
20,06 \mathrm{~A} \\
2,958 \\
15,11\end{array}$ & $\begin{array}{c}79,06 \mathrm{~A} \\
58,00 \mathrm{~B} \\
53,31 \mathrm{~B} \\
39,75 \mathrm{C} \\
32,69 \mathrm{C} \\
11,717 \\
22,24\end{array}$ & $\begin{array}{c}10,61 \mathrm{~A} \\
6,45 \mathrm{~B} \\
4,02 \mathrm{C} \\
1,79 \mathrm{D} \\
1,22 \mathrm{D} \\
1,422 \\
29,45\end{array}$ \\
\hline & x prof. & ns & ns & ns & ** \\
\hline
\end{tabular}


Tabela 15. Efeito do manejo de solo sobre a distribuição de $\mathrm{P}, \mathrm{Ca}, \mathrm{Mg}, \mathrm{K}, \mathrm{Al}, \mathrm{pH}$ e matéria orgânica no perfil de solo da gleba 3-A, após a colheita do feijão.

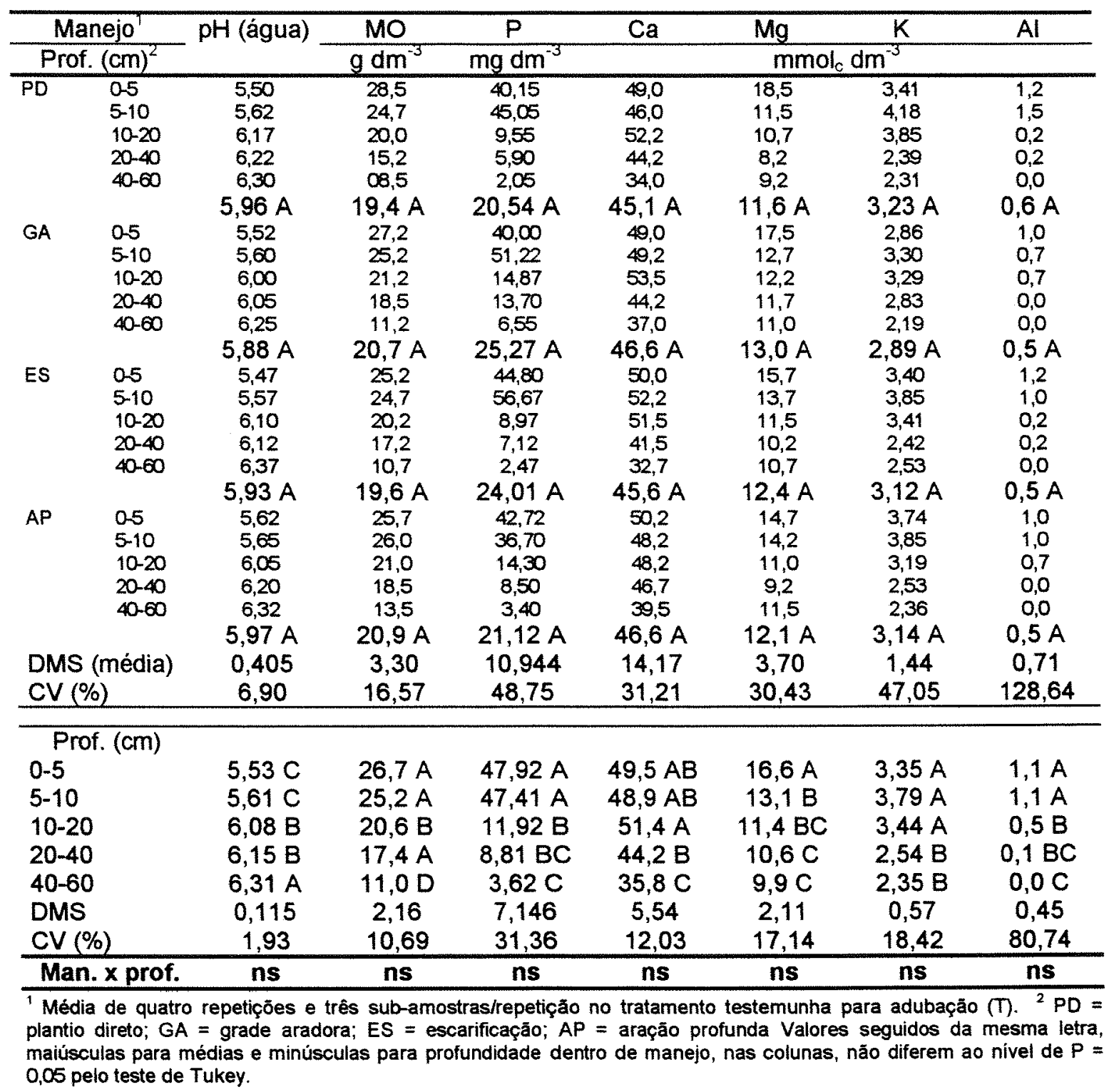


Tabela 16. Efeito do manejo de solo sobre a distribuição de $\mathrm{Cu}, \mathrm{Fe}, \mathrm{Mn}$ e $\mathrm{Zn}$ no perfil de solo da gleba 3-A, após a colheita do feijão.

\begin{tabular}{|c|c|c|c|c|c|}
\hline & Manejo & $\mathrm{Cu}$ & $\mathrm{Fe}$ & $\mathrm{Mn}$ & $\mathrm{Zn}$ \\
\hline & Prof. $(\mathrm{cm})^{2}$ & \multicolumn{4}{|c|}{$\mathrm{mg} \mathrm{dm}^{-3}$} \\
\hline \multirow[t]{6}{*}{ PD } & 0.5 & 4,17 & 21,50 & 104,50 & 11,30 \\
\hline & $5-10$ & 3,67 & 20,25 & 85,25 & 9,85 \\
\hline & $10-20$ & 3,10 & 20,25 & $63, \infty$ & \\
\hline & $20-40$ & 3,65 & 26,25 & 52,50 & 1,55 \\
\hline & $40-60$ & 4,15 & 29,50 & 49,00 & 1,32 \\
\hline & & $3,68 \mathrm{~A}$ & $23,55 \mathrm{~A}$ & $70,85 \mathrm{~A}$ & $5,15 \mathrm{~A}$ \\
\hline \multirow[t]{6}{*}{ GA } & 0.5 & 4,30 & 19,25 & 93,50 & 10,47 \\
\hline & $5-10$ & 3,52 & 18,75 & 85,25 & 8,42 \\
\hline & $10-20$ & 2,87 & 19,75 & 73,25 & 1,92 \\
\hline & $20-40$ & 3,35 & 23,75 & 63,50 & 2,30 \\
\hline & $40-60$ & 3,92 & 27,25 & $50, \infty$ & 1,70 \\
\hline & & $3,59 \mathrm{~A}$ & $21,75 \mathrm{~A}$ & $73,10 \mathrm{~A}$ & $4,96 \mathrm{~A}$ \\
\hline \multirow[t]{6}{*}{ ES } & 0.5 & 4,22 & 21,25 & 96,25 & 11,87 \\
\hline & $5-10$ & 3,72 & 21.50 & 82,50 & 11,25 \\
\hline & $10-20$ & 3,35 & 21,75 & 71,75 & 1,52 \\
\hline & $20-40$ & 3,77 & 27,25 & 54,75 & 1,40 \\
\hline & $40-60$ & 4,37 & 31,25 & 49,00 & 1,77 \\
\hline & & $3,89 \mathrm{~A}$ & $24,60 \mathrm{~A}$ & $70,85 \mathrm{~A}$ & $5,56 \mathrm{~A}$ \\
\hline \multirow[t]{6}{*}{ AP } & 0.5 & 4,07 & 20,75 & 88,00 & 10,25 \\
\hline & $5-10$ & 3,70 & 19,50 & 85,25 & 8,45 \\
\hline & $10-20$ & 3,27 & 21,75 & 77,00 & 3,60 \\
\hline & $20-40$ & 3,47 & 23,75 & $\mathfrak{3 , 0 0}$ & 2,12 \\
\hline & $40-60$ & $\begin{array}{l}3,90 \\
3,68\end{array}$ & 26,00 & $\begin{array}{l}47,50 \\
70,15\end{array}$ & $\begin{array}{c}1,37 \\
5,16\end{array}$ \\
\hline \multirow{3}{*}{\multicolumn{2}{|c|}{$\begin{array}{l}\text { DMS (média) } \\
\text { CV (\%) }\end{array}$}} & $3,68 \mathrm{~A}$ & $22,35 \mathrm{~A}$ & $72,15 \mathrm{~A}$ & $5,16 \mathrm{~A}$ \\
\hline & & 0,494 & 6,509 & 20,555 & 1,763 \\
\hline & & 13,43 & 28,59 & 29,02 & 34,29 \\
\hline \multicolumn{6}{|c|}{ Prof. $(\mathrm{cm})$} \\
\hline \multirow{2}{*}{\multicolumn{2}{|c|}{$\begin{array}{l}0-5 \\
5-10\end{array}$}} & $4,19 \mathrm{~A}$ & $20,69 \mathrm{~B}$ & $95,56 \mathrm{~A}$ & $10,97 \mathrm{~A}$ \\
\hline & & $3,65 \mathrm{~B}$ & $20,00 \mathrm{~B}$ & $84,56 \mathrm{~A}$ & $9,49 \mathrm{~A}$ \\
\hline \multicolumn{2}{|c|}{$10-20$} & $3,15 \mathrm{C}$ & $20,87 \mathrm{~B}$ & $71,25 \mathrm{~B}$ & $2,19 \mathrm{~B}$ \\
\hline \multicolumn{2}{|c|}{$20-40$} & $3,56 \mathrm{~B}$ & $25,25 \mathrm{~A}$ & $58,44 \mathrm{C}$ & $1,84 \mathrm{~B}$ \\
\hline \multicolumn{2}{|c|}{$40-60$} & $4,09 \mathrm{~A}$ & $28,50 \mathrm{~A}$ & $48,87 \mathrm{C}$ & $1,54 \mathrm{~B}$ \\
\hline \multicolumn{2}{|c|}{ DMS } & 0,324 & 3,823 & 12,253 & 1,706 \\
\hline \multicolumn{2}{|c|}{ CV $(\%)$} & 8,66 & 16,54 & 17,04 & 32,67 \\
\hline & Man. x prof. & ns & ns & ns & ns \\
\hline
\end{tabular}

\subsection{Análise física do solo}

As amostragens dos parâmetros físicos do solo foram realizadas anteriormente a semeadura do feijão (cinco meses após o preparo) e após a 
sua colheita, doze meses após o preparo e estes resultados são apresentados nas Tabelas 17 e 18.

Aos cinco meses após o preparo do solo (Tabela 17) foi verificado não haver feito significativo dos diferentes tipos de manejo sobre a micro e macroporosidades, porosidade total e massa especifica do solo.

Observou-se nas parcelas com tratamento PD e GA maior massa especifica do solo e menor macroporosidade em relação aos manejos ES e AP, com evidente aumento no perfil de 0 a $20 \mathrm{~cm}$, denotando compactação. Nos manejos relativos à escarificação e aração profunda houve um ligeiro aumento da massa específica na profundidade 5 a $10 \mathrm{~cm}$. Vieira \& Muzilli (1984) observaram a mesma tendência para o plantio direto, porém os resultados não foram estatisticamente significativos.

A análise física do solo, antes da instalação do experimento evidenciou a presença de camada compactada no perfil de 10 a $20 \mathrm{~cm}$ de profundidade, denotando a possibilidade de se ter iniciado o plantio direto de maneira inadequada.

Não houve efeito significativo da interação manejo-profundidade nos atributos físicos do solo.

Doze meses após o preparo (Tabela 18) observou-se não ter havido efeito significativo do manejo sobre a macro e microporosidade, porosidade total e massa especifica do solo. Porém os valores de massa especifica do solo, para todos os manejos, foram superiores em relação aos valores observados na primeira análise. Houve um aumento da massa específica nos perfis de 5 a $40 \mathrm{~cm}$ para todos os manejos, porém esta foi superior nos tratamentos relacionados ao plantio direto e gradeação. Resultado semelhante foi obtido por Vieira \& Muzzili (1984) em plantio direto, porém não ocorrendo o mesmo no preparo convencional. No plantio direto houve aumento na porcentagem de microporos e na porosidade total. Nos manejos com grade, escarificador e arado de aivecas a tendência foi desses valores se manterem constantes, inclusive para macroporosidade. 
Tabela 17. Efeito do manejo do solo sobre a macro e microporosidade, porosidade total e massa específica do solo na gleba $3 \mathrm{~A}$, antes da semeadura do feijão.

\begin{tabular}{|c|c|c|c|c|c|}
\hline \multicolumn{2}{|c|}{$\begin{array}{c}\text { Manejo } \\
\text { Prof. }(\mathrm{cm})^{2}\end{array}$} & $\begin{array}{c}\begin{array}{c}\text { Microporosidade } \\
(\%)\end{array} \\
49,80 \\
47,48\end{array}$ & $\begin{array}{c}\begin{array}{c}\text { Macroporosidade } \\
(\%)\end{array} \\
7,68 \\
743\end{array}$ & $\begin{array}{c}\begin{array}{c}\text { Porosidade Total } \\
(\%)\end{array} \\
57,48 \\
5,01\end{array}$ & $\begin{array}{c}\text { Massa especifica } \\
\left(\mathrm{g} / \mathrm{cm}^{3}\right)\end{array}$ \\
\hline$\overline{P D}$ & $\begin{array}{l}0-5 \\
5-10 \\
10-20 \\
20-40 \\
40-60\end{array}$ & $\begin{array}{c}49,80 \\
47,48 \\
48,60 \\
46,22 \\
46,82 \\
47,84 \mathrm{a}\end{array}$ & $\begin{array}{c}7,68 \\
7,43 \\
8,12 \\
9,28 \\
11,06 \\
8,71 \mathrm{a}\end{array}$ & $\begin{array}{c}57,48 \\
54,91 \\
56,72 \\
55,50 \\
57,50 \\
56,50 \mathrm{a}\end{array}$ & $\begin{array}{c}1,21 \\
1,27 \\
1,23 \\
1,20 \\
1,13 \\
1,21 \mathrm{a}\end{array}$ \\
\hline GA & $\begin{array}{l}0-5 \\
5-10 \\
10-20 \\
20-40 \\
40-60\end{array}$ & $\begin{array}{c}50,36 \\
48,61 \\
48,72 \\
47,34 \\
48,11 \\
48,63 \mathrm{a}\end{array}$ & $\begin{array}{c}8,65 \\
8,81 \\
8,29 \\
9,84 \\
10,34 \\
9,18 \mathrm{a}\end{array}$ & $\begin{array}{c}59,01 \\
57,42 \\
57,01 \\
57,18 \\
58,45 \\
57,81 \mathrm{a}\end{array}$ & $\begin{array}{l}1,20 \\
1,23 \\
1,25 \\
1,19 \\
1,13 \\
1,20 a\end{array}$ \\
\hline ES & $\begin{array}{l}0-5 \\
5-10 \\
10-20 \\
20-40 \\
40-60\end{array}$ & $\begin{array}{c}50,97 \\
49,54 \\
47,46 \\
46,28 \\
45,16 \\
47,88 \mathrm{a}\end{array}$ & $\begin{array}{c}11, \infty 9 \\
9,62 \\
8,78 \\
9,29 \\
11,56 \\
10,07 a\end{array}$ & $\begin{array}{c}52,06 \\
59,16 \\
56,24 \\
55,57 \\
57,72 \\
57,95 \text { a }\end{array}$ & $\begin{array}{c}1,16 \\
1,20 \\
1,17 \\
1,16 \\
1,10 \\
1,16 \text { a }\end{array}$ \\
\hline AP & $\begin{array}{l}0-5 \\
5-10 \\
10-20 \\
20-40 \\
40-60\end{array}$ & $\begin{array}{c}46,72 \\
50,67 \\
50,03 \\
49,61 \\
46,72 \\
48,75 a\end{array}$ & $\begin{array}{c}12,43 \\
10,21 \\
10,71 \\
10,03 \\
9,82 \\
10,64 a\end{array}$ & $\begin{array}{c}59,15 \\
60,88 \\
60,74 \\
59,64 \\
56,54 \\
59,39 a\end{array}$ & $\begin{array}{c}1,12 \\
1,18 \\
1,16 \\
1,16 \\
1,12 \\
1,15 \mathrm{a}\end{array}$ \\
\hline $\begin{array}{l}\text { DM } \\
\mathrm{CV}\end{array}$ & & $\begin{array}{c}5,27 \\
15,64 \\
\end{array}$ & $\begin{array}{c}2,45 \\
36,42 \\
\end{array}$ & $\begin{array}{c}4,47 \\
11,07 \\
\end{array}$ & $\begin{array}{c}0,064 \\
7,76 \\
\end{array}$ \\
\hline \multicolumn{6}{|c|}{ Prof. (cm) } \\
\hline $\begin{array}{l}0-5 \\
5-1 \\
10- \\
20- \\
40- \\
\text { DM } \\
\text { CV }\end{array}$ & & $\begin{array}{c}49,47 \mathrm{a} \\
49,07 \mathrm{a} \\
48,70 \mathrm{a} \\
47,36 \mathrm{a} \\
46,70 \mathrm{a} \\
3,03 \\
8,87\end{array}$ & $\begin{array}{c}9,96 \mathrm{a} \\
9,02 \mathrm{a} \\
8,98 \mathrm{a} \\
9,61 \mathrm{a} \\
10,70 \mathrm{a} \\
2,25 \\
32,83\end{array}$ & $\begin{array}{c}59,27 \text { a } \\
57,76 \text { a } \\
57,68 \text { a } \\
56,97 \text { a } \\
57,40 \text { a } \\
2,91 \\
7,09\end{array}$ & $\begin{array}{c}1,17 \mathrm{a} \\
1,22 \mathrm{a} \\
1,20 \mathrm{a} \\
1,18 \mathrm{a} \\
1,12 \mathrm{~b} \\
0,047 \\
5,62\end{array}$ \\
\hline Ma & $x$ prof. & ns & ns & ns & ns \\
\hline
\end{tabular}


Tabela 18. Efeito do manejo do solo sobre a macro e microporosidade, porosidade total e massa específica da gleba 3A, após a colheita do feijão.

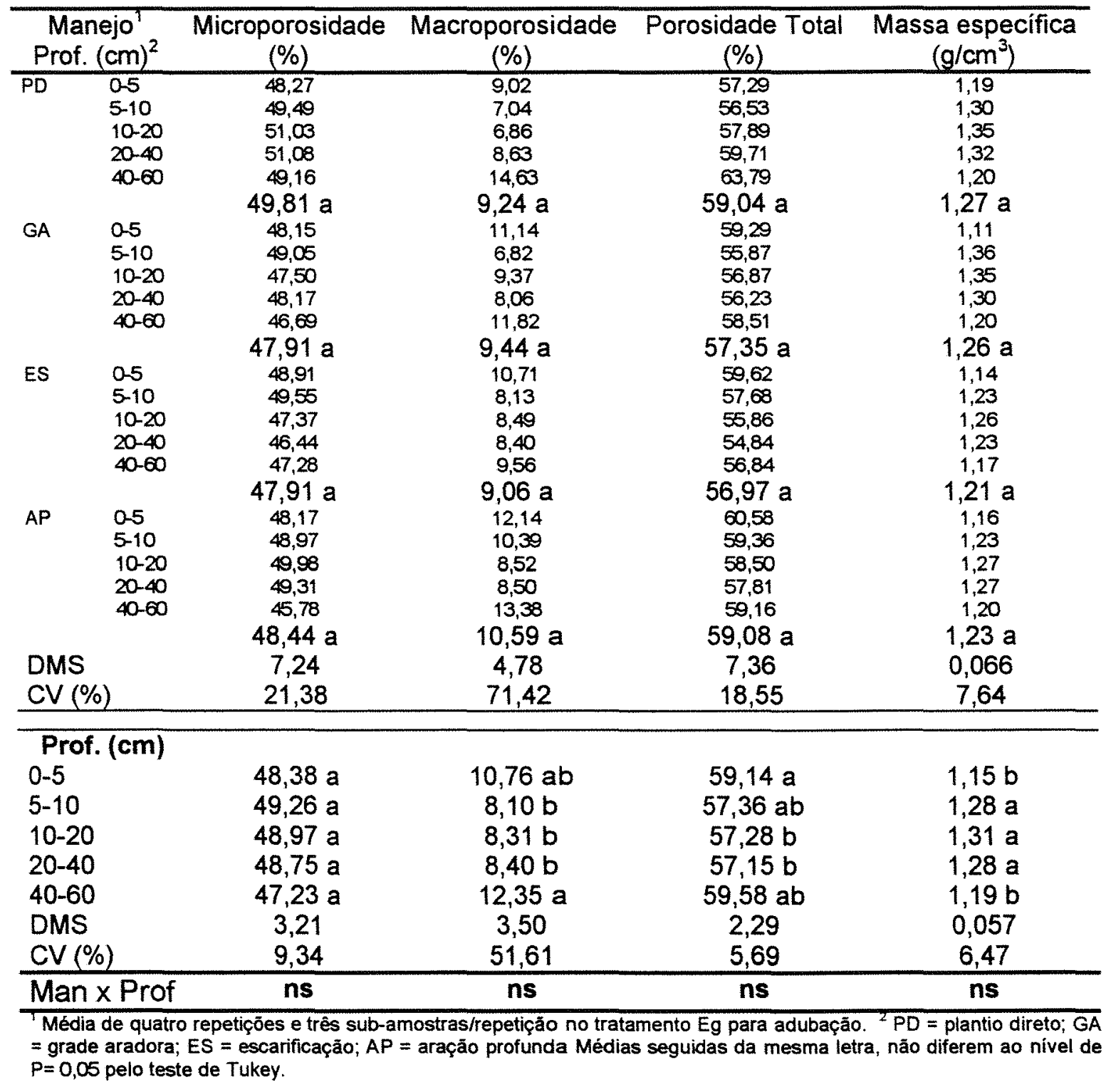

Neste período prevaleceu a tendência anteriormente observada para a interação manejo-profundidade. 


\subsection{Rendimento}

O rendimento de grãos das culturas de milho, soja e feijão foram obtidos após a colheita das mesmas em todos os tratamentos e são apresentados na Tabela 19.

Com relação à cultura do milho, os rendimentos obtidos foram baixos devido ao excesso de nebulosidade durante o ciclo da cultura e à incidência generalizada de Phaeosphaeria maydis. $O$ excesso de chuvas ocorreu durante o mês de novembro, época em que o milho apresentava-se com 4-6 folhas, que pode ter afetado o potencial produtivo da cultura (Apêndice 1); pois, segundo Fancelli \& Dourado Neto (1996) até o referido período, a restrição de qualquer fator de produção provoca perda irreversível no rendimento final do milho, pois - dreno forte nessa etapa refere-se ao desenvolvimento radicular e diferenciação da estrutura reprodutiva. Da mesma forma, Fancelli \& Dourado Neto (1997) também ressaltam a importância da luminosidade para a obtenção de elevados rendimentos na cultura.

A compactação constitui outro fator que pode ter contribuido para o menor rendimento do milho, porém, dependendo das condições edafoclimáticas, esta compactação pode não ser prejudicial, como Voorhees et al. (1989) relataram. Porém, nas condições do experimento este parâmetro, em função dos resultados obtidos, afetou a cultura do milho, possivelmente pela redução da disponibilidade de oxigênio às raízes, restringindo seu crescimento e desempenho.

No estudo da variável rendimento da cultura do milho, o valor de $F$ foi significativo ao nivel de $5 \%$ de probabilidade (teste de Tukey) para os tratamentos de manejo de solo e adubação, conforme evidenciado na Tabela 20.

O rendimento de grãos, independentemente da adubação avaliada, foi maior no manejo AP (6759 kg/ha), seguido de ES (6101 kg/ha), PD (6081 
$\mathrm{kg} / \mathrm{ha}$ ) e GA (5986 kg/ha), sendo que os três últimos não diferiram estatisticamente entre si.

Tabela 19. Efeito do manejo de solo e da adubação sobre o rendimento das culturas de milho, soja e feijão.

\begin{tabular}{|c|c|c|c|c|}
\hline Tratamentos & & & $\begin{array}{l}\text { ndimento } \\
(\mathrm{kg} / \mathrm{ha})\end{array}$ & \\
\hline \multirow[t]{2}{*}{ MANEJO ${ }^{1} / A D U B A C ̧ A ̃ O^{2}$} & & MILHO & SOJA & FEIJÃO \\
\hline & $T$ & 5893 & 3554 & 2221 \\
\hline \multirow[t]{3}{*}{ PD } & $\mathrm{Eg}$ & 6270 & 3634 & 2568 \\
\hline & & $6081 \mathrm{~B}$ & $3594 \mathrm{~A}$ & $2395 \mathrm{~B}$ \\
\hline & $T$ & 5729 & 3549 & 2273 \\
\hline \multirow[t]{3}{*}{ GA } & $\mathrm{Eg}$ & 6242 & 3622 & 2510 \\
\hline & & 5986 B & $3585 \mathrm{~A}$ & $2392 \mathrm{~B}$ \\
\hline & $T$ & 6021 & 3512 & 2345 \\
\hline \multirow[t]{3}{*}{ ES } & $\mathrm{Eg}$ & 6182 & 3822 & 2529 \\
\hline & & $6101 \mathrm{~B}$ & $3667 \mathrm{~A}$ & $2437 B$ \\
\hline & $\mathrm{T}$ & 6569 & 3493 & 2598 \\
\hline \multirow[t]{2}{*}{ AP } & $\mathrm{Eg}$ & 6950 & 3752 & 2923 \\
\hline & & $6759 \mathrm{~A}$ & $3622 \mathrm{~A}$ & $2760 \mathrm{~A}$ \\
\hline DMS (média) & & 398,91 & 258,34 & 164,01 \\
\hline CV (\%) & & 4,09 & 4,57 & 4,2 \\
\hline \multirow[t]{2}{*}{ Adubação } & $T$ & $6053 \mathrm{~B}$ & 3527 B & $2359 \mathrm{~B}$ \\
\hline & $\mathrm{Eg}$ & $6411 \mathrm{~A}$ & $3707 \mathrm{~A}$ & $2633 \mathrm{~A}$ \\
\hline DMS (média) & & 319,73 & 159,17 & 259,88 \\
\hline CV (\%) & & 4,56 & 3,91 & 9,25 \\
\hline
\end{tabular}

PD = plantio direto, $G A=$ Grade aradora, $E S=$ escarificaçăo, $A P=$ araçăo profunda. ${ }^{2} \mathrm{~T}=$ testemunha; $\mathrm{Eg}=$ reposição das exportaçōes pela colheita. 'Médias seguidas da mesma letra, nảo diferem entre si ao nivel de $P=0,05$ pelo teste de Tukey.

Os niveis de adubação afetaram significativamente o rendimento de grãos, sendo este maior no tratamento relativo à adubação Eg. Rüedell (1995) 
apontou a distribuição de raizes no perfil como um dos prováveis responsáveis para a obtenção desse resultado pois, em algumas situações o sistema radicular de uma cultura sob plantio direto tende, com o tempo, a se concentrar na superfície. Todavia, outros fatores do ambiente agrícola devem ter também contribuído para este resultado, como fertilidade do solo, disponibilidade de água, entre outros.

Ainda, ressalta-se que não houve efeito significativo da interação tipos de manejo-adubação no rendimento de grãos de milho.

Para a cultura da soja, o valor de $\mathrm{F}$ não foi significativo ao nível $5 \%$ de probabilidade (teste de Tukey) para os tratamentos de manejo de solo, porém foi significativo para as adubações, quanto ao rendimento de grãos, conforme observado na Tabela 19.

O rendimento médio da soja no tipo de manejo ES, AP, PD e GA foram, respectivamente, $3667 \mathrm{~kg} / \mathrm{ha}, 3622 \mathrm{~kg} / \mathrm{ha}, 3594 \mathrm{~kg} / \mathrm{ha}$ e $3585 \mathrm{~kg} / \mathrm{ha}$, não se constatando diferença estatística entre eles. Para as médias de adubação o maior rendimento foi obtido no tratamento $\mathrm{Eg}(3707 \mathrm{~kg} / \mathrm{ha})$.

A interação manejo-adubação não foi significativa, não sendo constatada diferença estatística para rendimento entre os manejos. Resultados diferentes foram obtidos por Sidiras et al. (1983) e Derpsch et al. (1991) os quais encontraram melhores rendimentos de soja sob plantio direto, comparados ao preparo convencional e preparo mínimo.

Para a cultura do feijão, observou-se diferença significativa entre os tipos de manejos de solo e nos valores médios para a variável adubação, quanto ao rendimento de grãos (Tabela 19). A aração profunda (2760 kg/ha) apresentou o maior rendimento, seguido da escarificação (2437 kg/ha), plantio direto $(2395 \mathrm{~kg} / \mathrm{ha})$ e gradeação $(2392 \mathrm{~kg} / \mathrm{ha})$, sendo que os três últimos não diferiram estatisticamente entre si. Estes resultados diferem dos apresentados por Stone \& Moreira (1995), onde o maior rendimento foi observado no sistema de plantio direto, embora o experimento em questão tenha contado com a prática da irrigação complementar. Todavia, em outro trabalho, Michel Junior et 
al. (1985) e Zaffaroni et al. (1991) encontraram rendimentos semelhantes comparando os sistemas convencional e direto.

Cumpre ressaltar que na área sob plantio direto foi diagnosticada maior incidência de Rhizoctonia solani p.v. phaseoli e Fusarium solani p.v. phaseoli no inicio do desenvolvimento da cultura (Apêndice 2). Este fato, provavelmente, foi suficiente para afetar negativamente o rendimento do feijão, contribuindo para a configuração da diferença estatística observada. Salienta-se que os mencionados patógenos são favorecidos por solos compactados ou por condições de baixa aeração. Nesse particular, o revolvimento do solo (destruição de camada de compactação) pode ter contribuído para a minimização do problema acima citado.

Ainda observou-se efeito significativo da adubação sobre o rendimento de grãos de feijão, o qual foi maior para a adubação $\mathrm{Eg}(2359 \mathrm{~kg} / \mathrm{ha})$ e menor para a testemunha $(2633 \mathrm{~kg} / \mathrm{ha})$.

A interação manejo-adubação não apresentou efeito significativo sobre o rendimento da cultura.

Em vista destes resultados, pode-se inferir que a resposta ao revolvimento do solo, após longo período sob plantio direto evidenciando camada de compactação, é variável para cada espécie, tornando-se imprudente qualquer recomendação generalizada à respeito.

\subsection{Análise econômica}

Os custos operacionais de produção foram determinados para cada cultura estudada e para todos os tratamentos sendo, estes dados, levantados durante o período de condução das culturas e, em seguida, atualizados para o valor do dólar do mês dezembro de 1998.

Os apêndices $3,4,5,6,7$ e 8 apresentam os demonstrativos de custo de produção para as culturas de milho, soja e feijão. 
Assim, considerando os tipos de manejo de solo, independentemente do tratamento de adubação, o tipo de preparo que apresentou maior custo de produção, para todas as culturas, foi a aração (AP), seguido da escarificação (ES), grade (GA) e plantio direto (PD).

Os resultados econômicos das culturas de milho, soja e feijão são apresentados nas Tabelas 20, 21, 22 e 23.

Com relação à cultura do milho, para a variável custo operacional total, o valor de $\mathrm{F}$ ao nivel de $5 \%$ de probabilidade foi significativo para os fatores manejo e adubação (Tabela 20). Dentre os valores médios para o manejo, o maior custo operacional foi relacionado ao tratamento AP (US\$ 424,36/ha), seguido de ES (US\$ 403,25/ha), GA (US\$ $\$ 84,77 /$ ha) e PD (US $\$ 383,71 /$ ha). Para média de adubação, o maior custo operacional total foi apresentado pelo tratamento Eg (US $\$ 445,19 / \mathrm{ha})$, seguido de T (US $\$ 352,85 / \mathrm{ha}$ ).

A maior receita bruta (Tabela 21) ocorreu no tipo de manejo AP (US\$ $541,10 / \mathrm{ha}$ ), seguido de ES (US\$ $\$ 88,60 / \mathrm{ha}$ ), PD (US $\$ 486,92 / \mathrm{ha}$ ) e GA (US\$ $479,23 / \mathrm{ha}$ ), sendo que os três últimos não diferiram estatisticamente entre si.

Para a variável receita líquida o valor de $\mathrm{F}$ não foi significativo ao nível de $5 \%$ de probabilidade (teste de Tukey) para os tratamentos de manejo de solo (Tabela 22). Os resultados, na média de manejo, para os tratamentos AP, PD, GA e ES, foram, respectivamente, US\$116,73/ha, US\$103,20/ha, US\$ $94,46 /$ ha e US $\$ 85,35 /$ ha. Para média de adubação, a maior receita líquida e relação benefício/custo foram apresentadas pelo tratamento $(T)$, possivelmente em função do nível de fertilidade do solo relativo a área experimental.

A relação benefício/custo não apresentou diferença estatística entre os tipos de manejo (Tabela 23), sendo significativa apenas para média de adubação.

A interação manejo-adubação não foi significativo ao nivel de $5 \%$ de probabilidade, no teste de Tukey. 
Tabela 20. Efeito do manejo do solo e da adubação sobre o custo operacional total das culturas de milho, soja e feijão.

\begin{tabular}{|c|c|c|c|c|}
\hline Tratamentos & & \multicolumn{3}{|c|}{$\begin{array}{l}\text { Custo operacional total } \\
\text { (US } \$ / \text { ha) }\end{array}$} \\
\hline MANEJO $1 / A D U B A C ̧ A ̃ O^{2}$ & & MILHO & SOJA & FEIJÃO \\
\hline & $T$ & 339,20 & 242,00 & 582,69 \\
\hline \multirow[t]{3}{*}{ PD } & $\mathrm{Eg}$ & 429,89 & 298,22 & 620,65 \\
\hline & & $383,71 \mathrm{D}$ & $270,11 \mathrm{D}$ & $601,67 \mathrm{D}$ \\
\hline & $T$ & 338,60 & 254,66 & 608,82 \\
\hline \multirow[t]{3}{*}{ GA } & $\mathrm{Eg}$ & 430,95 & 310,89 & 646,78 \\
\hline & & $384,77 \mathrm{C}$ & $282,77 \mathrm{C}$ & $627,80 \mathrm{C}$ \\
\hline & $\mathrm{T}$ & 357,07 & 273,14 & 624,21 \\
\hline \multirow[t]{3}{*}{ ES } & $\mathrm{Eg}$ & 449,42 & 329,36 & 662,16 \\
\hline & & $403,25 \mathrm{~B}$ & $301,25 \mathrm{~B}$ & $643,19 \mathrm{~B}$ \\
\hline & $T$ & 378,19 & 294,25 & 648,40 \\
\hline \multirow[t]{2}{*}{ AP } & $\mathrm{Eg}$ & 470,52 & 350,48 & 686,36 \\
\hline & & $424,36 \mathrm{~A}$ & $322,36 \mathrm{~A}$ & $667,38 \mathrm{~A}$ \\
\hline DMS (média) & & 0,00001 & 0,00001 & 0,00002 \\
\hline $\mathrm{CV}(\%)$ & & 0,001 & 0,001 & 0.001 \\
\hline \multirow[t]{2}{*}{ Adubação } & $T$ & $352,85 \mathrm{~B}$ & $266,00 \mathrm{~B}$ & $616,03 \mathrm{~B}$ \\
\hline & $\mathrm{Eg}$ & $445,19 \mathrm{~A}$ & $322,23 \mathrm{~A}$ & $654,00 \mathrm{~A}$ \\
\hline DMS (média) & & 0,00001 & 0.00001 & 0,00002 \\
\hline $\mathrm{CV}(\%)$ & & 0,001 & 0,001 & 0.001 \\
\hline
\end{tabular}

$\mathrm{PD}=$ plantio direto; $\mathrm{GA}$ - Grade aradora: $\mathrm{ES}$ = escarificação protunda; $\mathrm{AP}=$ aração profunda. ${ }^{2} \mathrm{~T}$ textemunha; Eg = reposição das exportações pela colheita. ${ }^{3}$ Médias seguidas da mesma letra nas colunas, nào diferem entre si ao nivel de $\mathrm{P}-0.05$ pelo teste de Tukey. 
Tabela 21. Efeito do manejo do solo e da adubação sobre o receita bruta das culturas de milho, soja e feijão.

\begin{tabular}{|c|c|c|c|c|}
\hline Tratamentos & & \multicolumn{3}{|c|}{$\begin{array}{c}\text { Receita bruta } \\
\text { (US\$/ha) }\end{array}$} \\
\hline \multicolumn{2}{|l|}{ MANEJO $O^{1} / A D U B A C ̧ A ̃ O^{2}$} & MILHO & SOJA & FEIJÃO \\
\hline & $\mathrm{T}$ & 471,72 & 702,34 & 1024,94 \\
\hline \multirow[t]{3}{*}{ PD } & $\mathrm{Eg}$ & 502,12 & 718,05 & 1184,22 \\
\hline & & 486,92 В & $710,20 \mathrm{~A}$ & $1104,58 \mathrm{~B}$ \\
\hline & $T$ & 458,75 & 701,34 & 1048,49 \\
\hline \multirow[t]{3}{*}{ GA } & $\mathrm{Eg}$ & 499,71 & 715,39 & 1159,10 \\
\hline & & $479,23 \mathrm{~B}$ & $708,27 \mathrm{~A}$ & $1103,79 \mathrm{~B}$ \\
\hline & $T$ & 482,18 & 694,04 & 1083,11 \\
\hline \multirow[t]{3}{*}{ ES } & $\mathrm{Eg}$ & 495,03 & 755,41 & 1166,91 \\
\hline & & $488,60 \mathrm{~B}$ & $724,72 \mathrm{~A}$ & $1125,01 \mathrm{~B}$ \\
\hline & $\mathrm{T}$ & 525,78 & 690,19 & 1199,46 \\
\hline \multirow[t]{2}{*}{$\mathrm{AP}$} & $\mathrm{Eg}$ & 556,41 & 741,47 & 1349,04 \\
\hline & & $541,10 \mathrm{~A}$ & $715,83 \mathrm{~A}$ & $1274,25 \mathrm{~A}$ \\
\hline DMS (média) & & 32,00 & 50,90 & 75,26 \\
\hline CV $(\%)$ & & 4,1 & 4,55 & 4,18 \\
\hline \multirow[t]{2}{*}{ Adubação } & $T$ & $484,61 \mathrm{~B}$ & $696,93 \mathrm{~B}$ & $1089,00 \mathrm{~B}$ \\
\hline & $\mathrm{Eg}$ & $513,32 \mathrm{~A}$ & $732,58 \mathrm{~A}$ & $1214,82 \mathrm{~A}$ \\
\hline DMS (média) & & 25,66 & 31,82 & 119,89 \\
\hline CV $(\%)$ & & 4,57 & 3,95 & 9,25 \\
\hline
\end{tabular}

'PD = plantio direto; $\mathrm{GA}$ - Grade aradora: $\mathrm{ES}$ = escarificação profunda: $\mathrm{AP}$ = aração profunda. "T testemunha: Eg = reposiçào das exportaços pela colheita. ${ }^{3}$ Médias seguidas da mesma letra nas colunas, não diferem entre si ao nivel de $\mathrm{P}=0.05$ pelo teste de Tukey. 
Tabela 22. Efeito do manejo do solo e da adubação sobre o receita líquida das culturas de milho, soja e feijão.

\begin{tabular}{|c|c|c|c|c|}
\hline Tratamentos & & \multicolumn{3}{|c|}{$\begin{array}{c}\text { Receita líquida }{ }^{3} \\
\text { (US\$/ha) }\end{array}$} \\
\hline \multicolumn{2}{|l|}{ MANEJO $1 / A D U B A C ̧ A ̃ O^{2}$} & MILHO & SOJA & FEIJÃO \\
\hline & $T$ & 134,18 & 460,33 & 442,26 \\
\hline \multirow[t]{3}{*}{ PD } & $\mathrm{Eg}$ & 72,23 & 419,82 & 563,58 \\
\hline & & $103,20 \mathrm{~A}$ & $440,07 \mathrm{~A}$ & $502,92 \mathrm{~B}$ \\
\hline & $T$ & 120,14 & 446,49 & 439,67 \\
\hline \multirow[t]{3}{*}{ GA } & $\mathrm{Eg}$ & 68,77 & 404,49 & 511,82 \\
\hline & & $94,46 \mathrm{~A}$ & $425,49 \mathrm{~A}$ & $475,74 \mathrm{~B}$ \\
\hline & $T$ & 125,10 & 420,90 & 458,90 \\
\hline \multirow[t]{3}{*}{ ES } & $\mathrm{Eg}$ & 45,61 & 426,04 & 504,74 \\
\hline & & $85,35 \mathrm{~A}$ & $423,47 \mathrm{~A}$ & $481,82 \mathrm{~B}$ \\
\hline & $\mathrm{T}$ & 147,59 & 395,94 & 551,05 \\
\hline \multirow[t]{2}{*}{$A P$} & $\mathrm{Eg}$ & 85,88 & 390,99 & 662,68 \\
\hline & & $116,73 \mathrm{~A}$ & $393,46 \mathrm{~A}$ & $606,87 \mathrm{~A}$ \\
\hline DMS (média) & & 32,00 & 51,05 & 75,09 \\
\hline $\mathrm{CV}(\%)$ & & 20,49 & 7,76 & 9,2 \\
\hline \multirow[t]{2}{*}{ Adubação } & $T$ & $131,75 \mathrm{~A}$ & $430,85 \mathrm{~A}$ & $472,55 \mathrm{~A}$ \\
\hline & $\mathrm{Eg}$ & $68,12 \mathrm{~B}$ & $410,34 \mathrm{~A}$ & $560,70 \mathrm{~A}$ \\
\hline DMS (média) & & 25,67 & 31,84 & 120,25 \\
\hline $\mathrm{CV}(\%)$ & & 22,8 & 6,72 & 20,68 \\
\hline
\end{tabular}

$\overline{P D}=$ plantio direto; $\mathrm{GA}=$ Grade aradora; $E S$ = escarificação profunda; $A \mathrm{P}=$ aração profunda. ${ }^{2} \mathrm{~T}$ = testemunha; $\mathrm{Eg}=$ reposição das exportaçōes pela colheita. ${ }^{3}$ Médias seguidas da mesma letra nas colunas, năo diferem entre si ao nivel de $P=0,05$ pelo teste de Tukey. 
Tabela 23. Efeito do manejo do solo e da adubação sobre a relação benefício/custo das culturas de milho, soja e feijão.

\begin{tabular}{|c|c|c|c|c|}
\hline \multirow{2}{*}{$\frac{\text { Tratamentos }}{\text { MANEJO }^{1} / \text { ADUBAÇÄO }}$} & & \multicolumn{3}{|c|}{ Relação benefício/custo ${ }^{3}$} \\
\hline & & MILHO & SOJA & FEIJÃO \\
\hline & $T$ & 1,40 & 2,90 & 1,75 \\
\hline \multirow[t]{3}{*}{ PD } & $\mathrm{Eg}$ & 1,17 & 2,40 & 1,91 \\
\hline & & $1,28 \mathrm{~A}$ & $2,65 \mathrm{~A}$ & $1,83 \mathrm{AB}$ \\
\hline & $T$ & 1,35 & 2,75 & 1,72 \\
\hline \multirow[t]{3}{*}{ GA } & $\mathrm{Eg}$ & 1,16 & $2,30 \mathrm{~b}$ & 1,79 \\
\hline & & $1,26 \mathrm{~A}$ & $2,52 \mathrm{AB}$ & $1,75 \mathrm{~B}$ \\
\hline & $T$ & 1,35 & 2,54 & 1,73 \\
\hline \multirow[t]{3}{*}{ ES } & $\mathrm{Eg}$ & 1,10 & 2,29 & 1,76 \\
\hline & & $1,22 \mathrm{~A}$ & $2,41 \mathrm{~B}$ & $1,74 \mathrm{~B}$ \\
\hline & $\mathrm{T}$ & 1,38 & 2,34 & 1,85 \\
\hline \multirow[t]{2}{*}{ AP } & $\mathrm{Eg}$ & 1,18 & 2,11 & 1,96 \\
\hline & & $1,28 \mathrm{~A}$ & $2,23 \mathrm{C}$ & $1,90 \mathrm{~A}$ \\
\hline DMS (média) & & 0,074 & 0,184 & 0,118 \\
\hline CV $(\%)$ & & 3,77 & 4,80 & 4,19 \\
\hline \multirow[t]{2}{*}{ Adubação } & $T$ & $1,37 \mathrm{~A}$ & $2,63 \mathrm{~A}$ & $1,76 \mathrm{~A}$ \\
\hline & $\mathrm{Eg}$ & $1,15 \mathrm{~B}$ & $2,28 \mathrm{~B}$ & $1,85 \mathrm{~A}$ \\
\hline DMS (média) & & 0,0073 & 0,113 & 0,181 \\
\hline CV (\%) & & 5,17 & 4,11 & 4,23 \\
\hline
\end{tabular}

Neste mesmo contexto, Siemens \& Oschwald (1978) encontraram rentabilidades equivalentes comparando o sistema convencional e direto, em milho. Porém, sabe-se que maior ou menor rentabilidade da cultura dependerá do rendimento obtido, como também dos preços auferidos e da estrutura de custos adotada. 
Estes dados confrontam com os resultados apresentados por outros autores pois, Muzilli (1981) relatou haver maiores retornos sob plantio direto, quando comparado ao convencional, devido apenas ao aumento do rendimento das culturas. No experimento em questão, a condição física do solo pode ter contribuído para a obtenção de menores rendimentos e ganhos no sistema de plantio direto.

$\mathrm{Na}$ cultura da soja, o tratamento que apresentou maior custo de produção, em média para manejo, foi AP (US\$322,36/ha) e o menor custo foi representado pelo plantio direto (US\$270,11/ha). Para média de adubação, o tratamento Eg apresentou maior custo total, US\$ 322,23/ha, diferindo estatisticamente da testemunha (US\$ 266,00/ha) conforme observado na Tabela 20.

Resultado semelhante foi observado por Salton \& Hernani (1997), onde a soja, em solos de alta fertilidade, não apresentou resposta a diferentes adubações. Os mesmos autores ainda relatam a importância da reposição de nutrientes ao solo pela exportação de nutrientes, via grãos, como critério de recomendação de adubação.

Para a variável receita bruta, o valor de $F$ não foi significativo ao nível de $5 \%$ de probabilidade para o teste de Tukey (Tabela 21). Para as médias de manejo, os tratamentos ES, AP, PD e GA apresentaram uma receita bruta absoluta de US\$724,72/ha, US $\$ 715,83 /$ ha, US $\$ 710,20$ /ha e US $\$ 708,27 /$ ha, respectivamente.

Para média de adubação, a maior receita bruta foi representada pelo tratamento Eg.

Os resultados de receita líquida não foram significativos para os tratamentos de manejo e adubação, ao nível $5 \%$ de probabilidade (Tabela 22). Em valores médios para o fator manejo, a receita líquida foi estatisticamente semelhante em todos os tratamentos, sendo de US $\$ 440,07$ /ha no PD, US\$ $425,49 /$ ha no GA, US $\$ 423,47 /$ ha no ES e US $\$ 393,46 /$ ha no AP. 
Para a média de adubação, a maior relação beneficio/custo foi dada pelo tratamento $(T)$. Contudo, a relação benefício/custo, para o fator manejo do solo, apresentou maior valor no tratamento PD (Tabela 23), sendo semelhante ao tipo de manejo GA. Assim, ficou evidente que este resultado foi obtido devido a pequena diferença existente entre o rendimento e custo operacional dos dois sistemas. Ressalta-se, no entanto que, na análise de resultados econômicos, a receita líquida deve ser considerada como primeira opção para fins de tomada de decisão, quando comparada à relação benefício/custo.

O estudo econômico da cultura do feijão revelou, para todos os tratamentos, maior custo operacional para o manejo AP (US\$ 616,03/ha), seguido de ES (US\$643,19/ha), GA (US\$627,80/ha) e PD (US\$601,67/ha). $\mathrm{Na}$ média, para adubação, o maior custo foi representado pelo tratamento $\mathrm{Eg}$ (US\$ 654,00/ha) (Tabela 20).

Os resultados de receita bruta foram significativos para todos os tratamentos, ao nível de $5 \%$ de probabilidade para o teste de Tukey (Tabela 21), porém, na média para manejo, a maior receita bruta foi relacionada ao tratamento AP (US\$1274,25/ha), seguido de ES (US\$ 1125,01/ha), PD (US\$ $1104,58 / \mathrm{ha})$ e GA US $\$ 1033,79 / \mathrm{ha})$, sendo que estes não apresentaram diferença estatística entre si.

A receita bruta, na média para adubação, apresentou resultados semelhantes as outras culturas, onde $\mathrm{Eg}$ foi US\$1214,82/ha e T, US\$ 1089,00/ha.

A receita líquida, na média para manejo, foi maior no tratamento AP (US\$ 606,87/ha), e menor nos manejos PD (US\$ 502,92/ha), ES (US\$ $481,82 /$ ha) e GA (US $\$ 475,74$ ), conforme apresentados na Tabela 22.

A relação benefício/custo, diferiu nos tratamentos de manejo, onde apresentou-se maior nos tipos de manejo AP e PD (Tabela 23).

A receita líquida e a relação benefício/custo não apresentaram diferença estatística entre os tratamentos de adubação. 
Os custos com o manejo AP foram mais elevados em relação aos outros métodos de movimentação do solo, devido ao maior consumo de combustivel, à menor capacidade de trabalho e à operação de gradeação suplementar. Corroborando os resultados apresentados por Hoogmoed \& Derpsch (1985) e Bowers Jr. (1989).

Comparando-se todas as culturas avaliadas, observou-se que a soja apresentou melhor relação benefício/custo, seguida do feijão e do milho. Todavia, reconhece-se que tal índice é função do local de produção, ano agrícola considerado e do momento de comercialização e, portanto, o referido resultado apenas apresenta valor comparativo, não devendo ser extrapolado para outras situações.

\subsection{Considerações finais}

No presente experimento, constatou-se nítida tendência de acúmulo de nutrientes no sistema plantio direto nas camadas superficiais, principalmente para fósforo, cálcio, magnésio e zinco, quando comparado aos demais sistemas. Os resultados relacionados à distribuição e ao teor dos nutrientes foi variável em função do tipo de delineamento utilizado (faixas), aliado à acentuada variabilidade espacial desses elementos no solo, dificultando a plena compreensão do fenômeno.

Ainda, cumpre salientar que os manejos aração (AP) e escarificação (ES) reduziram temporariamente a massa específica do solo, porém, o efeito destes implementos sobre a compactação do solo após um ano de cultivo já não foi mais observado. Todavia, a quebra da camada de compactação detectada, já seria suficiente para se retornar ao sistema de plantio direto.

Sob estes aspectos, é importante ressaltar a necessidade do monitoramento contínuo e sistemático das áreas sob plantio direto no tocante à compactação, a fim de se evitar futuros problemas, como redução de 
rendimento das culturas e aumento da incidência de fungos fitopatogênicos, configurando-se a exigência de eventual revolvimento.

Atenção especial deve ser dada ao fato da presença de camada compactada na área estudada $(10-20 \mathrm{~cm})$, evidenciando um provável erro no estabelecimento do sistema. Esta situação torna clara a necessidade de se proceder a correção da fertilidade e do adensamento do solo, para que o sistema de plantio direto possa manifestar todas as suas vantagens.

Ainda, como tem sido observada a tendência de redução nos preços dos produtos agrícolas, isto implica em redução nas margens de lucro e, portanto, torna-se imperiosa a utilização racional de insumos no sistema agrícola a fim de se minimizar custos e riscos, buscando o rendimento máximo econômico. Todavia, os custos ambientais inerentes ao sistema não poderiam ser negligenciados.

O manejo mais eficiente e o uso racional dos recursos externos (água, fertilizantes, defensivos e outros), objetivando a sustentabilidade e o maior retorno econômico da atividade será função da combinação entre as condições edafoclimáticas da região de interesse, da cultura explorada, da utilização de tecnologia apropriada e do momento econômico, entre outros, sem radicalismos e padronizações. 


\section{CONCLUSÕES}

A análise dos resultados obtidos no presente experimento permitiu a extração das seguintes conclusões:

1. A consolidação de camadas de compactação relacionada ao uso contínuo de plantio direto em solo argiloso afeta o rendimento das culturas, principalmente de milho e feijão.

2. O incremento no rendimento das culturas de milho e soja, proporcionado pela destruição da camada de compactação do solo, não se reverte em aumento da receita líquida das culturas mencionadas, devido à elevação dos custos de produção.

3. A cultura de feijão implantada em área mantida sob plantio direto por longo período, responde ao emprego da aração, resultando no aumento do rendimento e da receita liquida auferida pela cultura, principalmente em terrenos de elevada incidência de Fusarium sp. e Rhizoctonia solani pv. Phaseoli.

4. Os benefícios inerentes ao plantio direto são extremamente dependentes dos cuidados dispensados na etapa de implantação desse sistema. 


\section{REFERÊNCIAS BIBLIOGRÁFICAS}

ADÁMOLI, J.; MACÊDO, J.; AZEVEDO, L.G. de et al. Caracterização da região dos cerrados. In: GOEDERT, W.J. (Ed.) Solos dos cerrados: tecnologias e estratégias de manejo. São Paulo: Nobel, 1987. cap.2, p.33-98.

ALBUQUERQUE, J.A.; REINERT, D.J.; FIORON, J.E. et al. Rotação de culturas e sistemas de manejo do solo ao final de sete anos. Revista Brasileira de Ciência do Solo, v.19, n.1, p.115-119, 1995.

ANDREANI, D.B. Plantio direto no cerrado. Informações Agronômicas, n. 77, p. 5, 1997.

ANGHINONI, I.; SALER, R.L. Variabilidade espacial de propriedades químicas do solo no sistema plantio direto. In: CURSO SOBRE MANEJO DO SOLO NO SISTEMA PLANTIO DIRETO, Castro, 1995. Anais. Castro: Fundação $A B C, 1995$. p. $274-284$. 
ASSAD, M.L.R.C.L. Recursos biológicos: ocorrência e variabilidade. In: SIMPÓSIO SOBRE O CERRADO: BIODIVERSIDADE E PRODUÇÃO SUSTENTÁVEL DE ALIMENTOS E FIBRAS NOS CERRADOS, 8; INTERNATIONAL SYMPOSIUM ON TROPICAL SAVANNAS: BIODIVERSITY AND SUSTAINABLE PRODUCTION OF FOOD AND FIBERS IN THE TROPICAL SAVANNAS, 1., Planaltina, 1996. Anais. Planaltina: EMBRAPA, CPAC, 1996. p. 20-24.

BALBINO, L.C.; OLIVEIRA, E.F. de. Avaliação da alternância de sistemas de preparo de solo na cultura de trigo e soja. In: CONGRESSO BRASILEIRO DE ENGENHARIA AGRÍCOLA, 20., Londrina, 1991. Anais. Londrina: SBEA, 1992a. v. 2, p. 1338-1345.

BALBINO, L.C.; OLIVEIRA, E.F. de. Efeito de sistemas de preparo do solo no rendimento de grãos de trigo, soja e milho. In: CONGRESSO BRASILEIRO DE ENGENHARIA AGRÍCOLA, 20., Londrina, 1991. Anais. Londrina: SBEA, 1992b. v. 2, p. 1354-1360.

BALBINO, L.C. Sistema plantio direto. In: REUNIÃO NACIONAL DE PESQUISA DE FEIJÃO, 5., Goiânia, 1996. Anais. Goiânia: EMBRAPA, CNPAF; APA, 1997. v. 2, p. 219-228 (EMBRAPA. CNPAF. Documentos, 70).

BALBINO, L.C.; MOREIRA, J.A.A.; SILVA, J.G. da et al. Plantio direto. In: ARAÚJO, R.S.; RAVA, C.A.; STONE, L.F. et al. (Coord.) Cultura do feijoeiro comum no Brasil. Piracicaba: POTAFOS, 1996. p. 301-352. 
BATAGLIA, O.C.; RAIJ, B. van. Eficiência de extratores na determinação de boro em solos. Revista Brasileira de Ciência do Solo, v.14, n.1, p.21-31, 1990.

BAUMER, K.; BAKERMANS, A.P. Zero-tillage. Advances in Agronomy, v.25, p. $77-121.1973$.

BAYER,C.; MIELNICZUK, J. ; PAVINATO, A. Características químicas do solo afetadas por métodos de preparo e sistemas de cultura. Revista Brasileira de Ciência do Solo, v.21, n.1, p.105-112, 1997.

BERTONI, J.; LOMBARDI NETO, F. Conservação do solo. Piracicaba: Livroceres, 1985. $392 \mathrm{p}$.

BLEVINS, R.L.; THOMAS, M.S.; FRYE, W.W. et al. Changes in soil properties after 10 years continuous non-tilled and convertionally tilled corn. Soil Tillage Research, v..3, p. 135-146, 1983.

BOWERS JUNIOR, C.G. Tillage draft and energy measurements for twelve Southeastern soil series. Transactions of the American Society of Agricultural Engineers, St. Joseph, v.32, p. 1492-502, 1989. 
BRAGAGNOLO, N. Uso dos solos altamente suscetiveis à erosão. In: PEREIRA, V. de P.; FERREIRA ,M.E.; CRUZ, M.C.P. da (Ed). Solos altamente suscetíveis à erosão. Jaboticabal: UNESP, FCAV; SBCS, 1994. p. 3-16.

BÜLL, L.T. Nutrição mineral do milho. In: BÜLL, L.T.; CANTARELLA, H. (Ed.) Cultura do milho: fatores que afetam a produtividade. Piracicaba: POTAFOS, 1993. p.63-145.

CABRAL, J.I. Pronunciamento do Presidente da EMBRAPA. In: SIMPÓSIO SOBRE O CERRADO; USO E MANEJO, 5., Brasília, 1979. Anais. Brasília: Editerra, 1980. p.2-7.

CARDOSO, A.N. Manejo e conservação do solo na cultura da soja. In: SIMPÓSIO SOBRE A CULTURA DA SOJA NO CERRADO, 1992. Uberaba, Cultura da soja nos cerrados: anais. Piracicaba: POTAFOS, 1993. p.71-104.

CENTURION, J.F.; DEMATTE, J.L.I.; FERNANDES, F.M. Efeitos de sistemas de preparo nas propriedades químicas de um solo Cerrado cultivado com soja. Revista Brasileira de Ciência do Solo, v.9, n.2, p.267-270, 1985.

CHAVES, H.M.L. Efeitos do plantio direto sobre o meio ambiente. In: SATURNINO, H.M.; LANDERS, J.N. (Ed.) O meio ambiente e o plantio direto. Brasilia: EMBRAPA, SPI, 1997. cap.3. p. 57-66. 
COBRA NETO, A.; ACCORSI, W.R.; MALAVOLTA, E. Estudos sobre a nutrição mineral do feijoeiro (Phaseolus vulgaris L.; var. Roxinho). Anais da Escola Superior de Agricultura Luiz de Queiroz, v.28, p.257-274, 1971.

COBUCCI, T.; FERREIRA, F.A.; SILVA, A.A. da. Controle de plantas daninhas. In: ARAÚJO, R.S.; RAVA, C.A.; STONE, L.F et al. (Coord.) Cultura do feijoeiro comum no Brasil. Piracicaba: POTAFOS, 1996. p. 433-464.

COIMBRA, A. Sucesso do sistema depende do gerenciamento eficaz. Jornal Informativo Diário do II Seminário Internacional do Sistema Plantio Direto. Passo Fundo, 08 out. 1997. p.2.

CUNHA, A.S. Uma avaliação da sustentabilidade da agricultura nos Cerrados. Brasilia: IPEA, 1994. 256p.

DERPSCH, R. Agricultura sustentável. In: SATURNINO, H. M.; LANDERS, J.N. (Ed.) O meio ambiente e o plantio direto. Brasília: EMBRAPA, SPI, 1997. cap. 2. p.29-48.

DERPSCH, R.; ROTH, C.H.; SIDIRAS, N. et al. Controle da erosão no Paraná, Brasil: sistemas de cobertura do solo, plantio direto e preparo conservacionista do solo. Eschborn: GTZ, 1991. 272 p. 
DOWDING, E.; FERGUSSON, J.A.; BECKER, C.F. Comparison of four summer-fallow tillage methods based on seasonal tillage energy requirement, moisture conservation, and crop yield. Transactions of the ASAE, v.10, p. $1-3,8,1967$.

DILLON, J.L. Avaliação de tecnologias agrícolas alternativas, sob risco. Revista de Economia Rural, v.15, n.2, p.17-41, 1977.

EMPRESA BRASILEIRA DE PESQUISA AGROPECUÁRIA. Serviço Nacional de Levantamento e Conservação do Solo. Atlas do meio ambiente do Brasil. Brasília: EMBRAPA, SPI, 1984. 130p.

EMPRESA BRASILEIRA DE PESQUISA AGROPECUÁRIA. Centro Nacional de Pesquisa de Solos. Manual de métodos de análise de solo. 2.ed. Rio de Janeiro, 1997. 212p. (EMBRAPA. CNPS. Documentos, 1).

FAGERIA, N.K. Solos tropicais e aspectos fisiológicos das culturas. Brasilia: EMBRAPA, DPU, 1989. 425 p. (EMBRAPA. CNPAF. Documentos, 18).

FANCELLI, A.L. Cultura do milho: a importância da tecnologia. Informações Agronômicas, n.78, p. 4, jun. 1997. 
FANCELLI, A.L.; DOURADO NETO, D. Milho: fisiologia da produção. In: SEMINÁRIO SOBRE FISIOLOGIA DA PRODUÇÃO E MANEJO DE ÁGUA E DE NUTRIENTES NA CULTURA DO MILHO DE ALTA PRODUTIVIDADE, Piracicaba, 1996. Piracicaba: POTAFOS, 1996. p. 129.

FANCELLI, A.L.; DOURADO-NETO, D. Milho: ecofisiologia e rendimento. In: FANCELLI, A.L.; DOURADO-NETO, D. (Coord.) Tecnologia da produção de milho. Piracicaba: Publique, 1997. p. 157-170.

FNP. CONSULTORIA \& COMËRCIO. AGRIANUAL 98: Anuário estatístico da agricultura brasileira. São Paulo, 1997. 392 p.

FAVARIN, J.L.; FANCELLI, A.L. Adequação de sistemas de produção em relação a alguns elementos do ambiente agrícola. In: ENCONTRO PAULISTA DE PLANTIO DIRETO, 2., Assis, 1989. Trabalhos apresentados. Piracicaba: FEALQ; ESALQ,USP, 1989. p. 37-72.

FERRAZ, E.C. Ecofisiologia vegetal e a produção de alimentos no cerrado. In: CASTRO, P.R.C.; FERREIRA, S.O.; YAMADA, T. (Ed.). Ecofisiologia da produção agrícola. Piracicaba: POTAFOS, 1987. p. 101-111.

FISCHER, K.S.; PALMER, F.E. tropical maize. In: GOLDSWORTHY, P.R.; FISCHER, N.M. (Ed.) The physiology of Tropical fields crops. Wiley, 1984. p.231-48. 
FREITAS, P.L. de. Manejo físico do solo. In: SIMPÓsIO SOBRE MANEJO E CONSERVAÇÃO DO SOLO NO CERRADO, 1., Goiânia, 1990. Anais. Campinas: Fundação Cargill, 1992. p. 117-139.

GALLO, R.; MIYASAKA, S. Composição química do feijoeiro e absorção de elementos nutritivos do florescimento à maturação. Bragantia, v.20, n.40, p.867-874, 1961.

GASSEN, D.N.; GASSEN, F.R. Plantio direto: o caminho do futuro. Passo Fundo: Aldeia Sul, 1996. 207p.

GENTIL, L.V. Aspectos econômicos do plantio direto. In: SEMINÁRIO INTERNACIONAL DO SISTEMA PLANTIO DIRETO, 1., Passo Fundo, 1995. Resumos. Passo Fundo: EMBRAPA, CNPT, 1995. p. 9-12.

GOEDERT, W.J. Uso e manejo dos recursos naturais do Cerrado: solo e clima. In: SIMPÓSIO SOBRE O CERRADO; USO E MANEJO, 5., Brasília, 1979. Anais. Brasília: Editerra, 1980. p.475-498.

GOEDERT, W.J. Região dos Cerrados: potencial agrícola e sua política para desenvolvimento. Pesquisa Agropecuária Brasileira, v.24, n.1, p.12-17, 1989.

HOOGMOED, W.B.; DERPSCH, R. Chisel phoughing as an alternative tillage system n Parana, Brasil. Soil \& Tillage Research, v.6, p. 53-67, 1985. 
KAPUSTA, G; STRIERER, C.F. Herbicial weed control in stubble no-till planted corn. Weed Science, Champaign, v.24, p.605-611,1976.

KER, J.C.; PEREIRA, N.R.; CARVALHO Jr, W. et al Cerrados: solos, aptidão e potencialidade agrícola. In: SIMPÓSIO SOBRE MANEJO E CONSERVAÇÃO DO SOLO NO CERRADO, Goiânia, 1990, Anais. Campinas: Fundação Cargill, 1992. p. 1-31.

KLINK, C.A.; MACEDO, D.F.; MUELLER, C.C. De grão em grão o Cerrado perde espaço. Cerrado: impactos do processo de ocupação. Brasilia: WWF-PROCER, 1995. (Documento para discussão)

KLINK, C.A. Relação entre o desenvolvimento agrícola e a biodiversidade. In: SIMPÓSIO SOBRE O CERRADO: BIODIVERSIDADE E PRODUÇÃO SUSTENTÁVEL DE ALIMENTOS E FIBRAS NOS CERRADOS, 8.; INTERNATIONAL SYMPOSIUM ON TROPICAL SAVANNAS: BIODIVERSITY AND SUSTAINABLE PRODUCTION OF FOOD AND FIBERS IN THE TROPICAL SAVANNAS, 1., Planaltina, 1996. Anais. Planaltina: EMBRAPA, CPAC, 1996. P.25-27.

LAL, R. No tillage effects on soil properties under different crops in Westem Nigeria. Soil Science Society of America Journal, v. 40, p.762-768, 1976.

LANDERS, J.N. Fascículo de experiências de plantio direto no cerrado. Brasília: APDC, 1995. 261p. 
LAURENTI, A.C.; FUENTES, L.R. Avaliação de custos, rentabilidade e risco. In: IAPAR. Plantio direto no Estado do Paraná. Londrina: IAPAR, 1981. p. 215-237. (IAPAR. Circular, 23).

LAZARINI, E.; BELLINGIERI, A.A.; ATHAYDE, M.L.F. Extração e exportação de nutrientes por genótipos de soja, semeados em diferentes épocas. In: CONGRESSO BRASILEIRO DE CIÊNCIA DO SOLO, 25., 1995, Viçosa, MG. Resumos expandidos. Viçosa: SBCS, 1995. v.3. p.1374-1376.

LOPES, A.S. Solos sob cerrado: características, propriedades e manejo. Piracicaba: Instituto da Potassa \& Fosfato; Instituto Internacional da Potassa, 1983. 162p.

LOPES, P.R.C.; COGO, N.P.; LEVIEN, R. Eficiência relativa de tipo e quantidade de resíduos culturais espalhados uniformenente sobre o solo na redução da erosão hídrica. Revista Brasileira de Ciência do Solo, v.11, n.1, p.71-75, 1987.

MERTEN, G.H.; MIELNICZUK, J. Distribuição do sistema radicular e dos nutrientes em Latossolo Roxo sob dois sistemas de preparo de solo. Revista Brasileira de Ciência do Solo, v.15, n.3, p.369-374, 1991.

MICHEL JUNIOR, J.A.; FORNSTROM, K.J.; BORRELLI, J. Energy requirements of two tillage systems for irrigated sugarbeets, drybeans and corn. Transactions of the ASAE, v.28, n.6, p.1731-1735, 1985. 
MOTTA, A.C.V.; PREVEDELLO, B.M.S. Micronutrientes: fatores que afetam sua disponibilidade e resposta das culturas. In: CURSO SOBRE MANEJO DO SOLO NO SISTEMA PLANTIO DIRETO, Castro, 1995. Anais. Castro: Fundação ABC, 1995. p. 296-337.

MULLINS, C.A.; TOMPKINS, F.D.; PARKS, W.L. Effects of tillage methods on soil nutrient distribution, plant nutrient absorption, stand and yield of snap beans and lima beans. Journal of the American Society for Horticultural Science, v.105, p.591-593, 1980.

MUZZILI, O. Manejo da fertilidade do solo. In: INSTITUTO AGRONÔMICO DO PARANÁ. Plantio direto no Estado do Paraná. Londrina, 1981, p. 43-57. (IAPAR, Circular, 23).

MUZILLI, O. Influência do sistema de plantio direto, comparado ao convencional, sobre a fertilidade da camada arável do solo. Revista Brasileira de Ciência do Solo, v.7, n.1, p. 95-102, 1983.

MUZILLI, O. Fertilidade do solo em plantio direto. In: FANCELLI, A.L. Atualização em plantio direto. Campinas: Fundação Cargill, 1986. p. 147-160.

NEVES, E.M.; SHIROTA, R. Considerações sobre a importância, determinação e atualização dos custos agrícolas. Revista da ADEALQ, n.4, p.62-69, 1985. 
OADES, J.M. Soil organic matter structural stability mechanisms and implications for management. Plant and Soil, Dordrecht, v.76, p. 319-37, 1984.

ORGANIZAÇÃO DAS COOPERATIVAS DO ESTADO DO PARANÁ. Efeito dos sistemas de preparo do solo nas suas características físicas e quimicas e no rendimento de trigo e soja em Latossolo Roxo. Cascavel, 1990. 54 p. (OCEPAR. Resultados de Pesquisa 4.)

PARRA, M.S. Dinâmica da matéria orgânica e de nutrientes num latossolo roxo distrófico submetido aos sistemas de plantio convencional e direto e a diferentes sucessões de cultura. Viçosa, 1986. 94p. Dissertação (Mestrado) - Universidade Federal de Viçosa.

PEIXOTO, R.T.G.; ELTZ, F.L.F. Avaliação da fertilidade do solo em plantio direto na região de Campos Gerais, Paraná. In: REUNIÃO BRASILEIRA DE FERTILIDADE DO SOLO, 17., Londrina, PR, 1986. Resumos. Londrina, Sociedade Brasileira de Ciência do Solo, EMBRAPA, IAPAR, 1986. p. $56-7$.

RAIJ, B. van. Fertilidade do solo e adubação. Piracicaba: Ceres; Potafos. 1991. $343 p$ 
RESCK, D.V.S. Manejo de solos e sustentabilidade dos sistemas agrossilvopastoris na região dos Cerrados. In: SIMPÓSIO SOBRE O CERRADO: BIODIVERSIDADE E PRODUÇÃO SUSTENTÁVEL DE ALIMENTOS E FIBRAS NOS CERRADOS, 8.; INTERNATIONAL SYMPOSIUM ON TROPICAL SAVANNAS: BIODIVERSITY AND SUSTAINABLE PRODUCTION OF FOOD AND FIBERS IN THE TROPICAL SAVANNAS, 1., Planaltina, 1996. Anais. Planaltina: EMBRAPA, CPAC, 1996. p.81-89.

RüEDELL, J. Plantio direto na região de Cruz Alta. Cruz Alta: FUNDACEP; BASF, 1995. $134 \mathrm{p}$.

SÁ, J.C.M. Manejo da Fertilidade do solo no plantio direto. Castro: Fundação $A B C, 1993.96 \mathrm{p}$.

SÁ, J.C.M. O sistema de plantio direto: transformações e benefícios ao agroecossistema. In: CURSO SOBRE MANEJO DO SOLO NO SISTEMA PLANTIO DIRETO, Castro, 1995. Anais. Castro: Fundação ABC, 1995. p. 9-20.

SÁ, J.C.M. Calagem no sistema plantio direto. Revista Plantio Direto, v.41, p.18-22, 1997. 
SALOMÃO, C.C. Sistemas de plantio direto e convencional: um enfoque de análise de decisão. Piracicaba, 1990. 127 p. Dissertação (Mestrado) Escola Superior de Agricultura "Luiz de Queiroz", Universidade de São Paulo.

SALTON, J.C.; HERNANI, L.C. Resposta de cultivares de soja à adubação, em solo de alta fertilidade, no sistema plantio direto. Comunicado Técnico do Centro de Pesquisa Agropecuária do Oeste, n.20, p.1-5, 1997.

SANCHEZ, P.A.; LOPES, A.S.; BUOL, S.W. Cerrado Research Center: preliminary project proposal. North Carolina State University, 1974. (Mimeografado)

SHULTZ, L.A. Manual do plantio direto: técnicas e perspectivas. 2. ed. Porto Alegre: Editora Sagra, 1987. 124 p.

SIDIRAS, N.; DERPSCH, R.; MONDARDO, A. Influência de diferentes sistemas de preparo do solo na variação da umidade e rendimento de soja, em Latossolo roxo distrófico (oxisol). Revista Brasileira de Ciência do Solo, v.7, n.1, p.103-106, 1983.

SIEMENS, J.C.; OSCHWALD, W.R. Corn - soybean tillage systems: erosion control, effects on crop production, costs. Transactions of ASAE, v.21, n.3, p.293-302, 1978. 
SILVA, D.B. da; MEDEIROS, C.A.B.; FRANZ, C.A.B. et al. Manejo de latossolos sob irrigação na Região dos Cerrados. In: Relatório técnico anual 1985-1987 do Centro de Pesquisa Agropecuária dos Cerrados. Brasília: EMBRAPA, CPAC, 1991. 339 p.

SILVEIRA, P.M. da; SILVA, S.C. da; SILVA, O.F. da et al. Estudo de sistemas Irrigados. Pesquisa Agropecuária Brasileira, v.29, n.8, p.1243-1252, ago. 1994.

SIMPSON, L.A.; GUMBS, F.A. A comparison of three tillage methods for maize (Zea mays L.) and cowpea (Vigna unguiculata (L.) Walp.) production on a coastal clay soil in Guyana. Tropical Agriculture, v.62, p. 248-52, 1985 a.

SIMPSON, L.A.; GUMBS, F.A. A comparison of conventional tillage and notillage for cowpea (Vigna unguiculata (L.) Walp.) production. Tropical Agriculture, v.62, p. 25-29, 1985b.

SIQUEIRA, J.O.; MOREIRA, F.M. de S. Microbiologia do solo e a sustentabilidade agrícola: enfoque em fertilidade do solo e nutrição vegetal. In: REUNIÃO BRASILEIRA DE FERTILIDADE DO SOLO E NUTRIÇÃO DE PLANTAS, 22., Manaus, 1996. Palestras. Manaus: Editora da Universidade do Amazonas, 1996. p.1-42.

SORRENSON, W.J.; MONTOYA, L.J. Implicações econômicas da erosão do solo e de práticas conservacionistas no Paraná, Brasil, IAPAR. Londrina: GTZ, Eschborn. 231 p. (Não publicado) 
SORRENSON, W.J.; MONTOYA, L.J. Implicações econômicas da erosão do solo e do uso de algumas práticas conservacionistas no Paraná. Londrina: IAPAR, 1989. 109 p. (IAPAR. Boletim Técnico, 21)

STONE, L.F; MOREIRA, J.A.A. Respostas de duas cultivares de feijão a diferentes lâminas de irrigação, sob diferentes preparos de solo. In: CONGRESSO BRASILEIRO DE CIÊNCIA DO SOLO, 25, Viçosa, 1995. Resumos expandidos. Viçosa: SBCS; UFV, 1995. p.1743-1745.

TANAKA, R.T.; MASCARENHAS, H.A.A.; BORKERT, C.M. Nutrição mineral da soja. In: SIMPÓSIO SOBRE A CULTURA DA SOJA NO CERRADOS, Uberaba,1992. Cultura da soja nos cerrados: anais. Piracicaba: POTAFOS, 1993. p.105-135.

TAYLOR, H. M. Methods of studying root systems in the field. HortScience, v.21, n.4, p.952-956, 1996.

THOMAS, G.N.; BLEVINS, R.L.; PHILLIPS, R.E. et al. Effect of a killed sod mulch on nitrate moviment and corn yield. Agromony Journal, v.65, p.7369, 1973.

THORNTHWAITE, C.W.; MATHER, J.R. The water balance. Drexel Institute of Technology, v.8, n.1, p.1-14, 1955. 
TORMENA, C.A. Resíduos culturais: efeitos no controle da erosão e alterações em propriedades físicas do solo. In: CURSO SOBRE MANEJO DO SOLO NO SISTEMA PLANTIO DIRETO, Castro, 1995. Anais. Castro: Fundação ABC, 1995. p.37-51.

TURRA, F.E. Agricultura: custo de produção. In: FNP CONSULTORIA \& COMÉRCIO. Agrianual 99: anuário da agricultura brasileira. São Paulo, 1998. p. $57-60$.

VAN DOREN, D.M.; TRIPLET, G.B.; ENRY, J.E. Influence of long-term tillage crop rotation, and soil type combinations on corn yield. Soil Science Society of America Journal, v.40, n.1, p.100-105. 1976.

VASCONSCELOS, H.P; LANDERS, J.N. Agricultura sustentável no cerrado. In: PEREIRA, V.P.; FERREIRA, M.E.; CRUZ, M.C.P. da (Ed). Solos altamente suscetíveis à erosão. Jaboticabal: UNESP; FCAV; SBCS, 1994. p. 181-203.

VIEIRA, M.J.; MUZZILI, O. Características físicas de um Latossolo VermelhoEscuro sob diferentes sistemas de manejo. Pesquisa Agropecuária Brasileira, v.19, n.7, p.873-882, 1984.

VOORHEES, W.B.; LINDSTROM, M.J. Long -term effects of tillage method on Soil tilth independent of wheel traffic compaction. Soil Sci. Soc. Am. J., Madison, v. 48, p.152-6, 1984. 
VOORHEES, W.B.; JOHNSON,J.F.; RANDALL, G.N. et al. Corn growth and yield as affected by surface and sulsoil compaction. Agronomy Journal, v.81, p.294-303, 1989.

WILDNER, L.P. Manejo do solo para a cultura do feijão: principais caracteristicas e recoemndações técnicas. In: EMPRESA DE PESQUISA AGROPECUÁRIA E DIFUSÃO DE TECNOLOGIA DE SANTA CATARINA S.A. A cultura do feijão em Santa Catarina. Florianópolis, 1992. p. 83114.

WOLF, J.M. Probabilidades de ocorrência de periodos secos na estação chuvosa para Brasilia. Pesquisa Agropecuária Brasileira, v.12, p.141-50, 1977.

YOKOYAMA, L.P.; KLUTHCOUSKI, J.; OLIVEIRA, I.P. et al. Sistema Barreirão: análise de custo/benefício e necessidade de máquinas e implementos agrícolas. Goiânia: EMBRAPA, CNPAF, 1995. 31p. (EMBRAPA. CNPAF. Documentos, 56).

ZAFFARONI, E.; BARROS, H.H.de A.; NÓBREGA, J.A.M. et al. Efeito de métodos de preparo do solo na produtividade e outras características agronômicas de milho e feijão no Nordeste do Brasil. Revista Brasileira de Ciência do Solo, v.15, n.1, p.99-104, 1991.

WALKLEY, A.; BLACK, I.A. An examination of the digtyareff method for determining soil organic matter and a proposed modification of the chromic acid titration method. Soil Science, v.37, p. 29-38, 1934. 
APÊNDICE 
Apêndice 1. Dados climáticos do municipio de Santa Helena (GO) e da Fazenda Três Irmãos, ocorridos durante o período experimental $(1996 / 97)$.

\begin{tabular}{lcccccc}
\hline \multirow{2}{*}{ Mês } & Precipitação $^{1}$ & \multicolumn{2}{c}{ T. Média $\left({ }^{\circ} \mathrm{C}\right)$} & ETA $^{2}$ & ${\text { UR } \text { ar }^{3}}^{2}$ & Insolação \\
\cline { 2 - 7 } & $(\mathrm{mm})$ & Minima & Máxima & $(\mathrm{mm})$ & $(\%)$ & h luz mês $^{-1}$ \\
\hline Outubro & 169,5 & 20,1 & 34,0 & 138,4 & 69,6 & 140,6 \\
Novembro & 496,5 & 20,6 & 31,2 & 115,3 & 73,2 & 117,9 \\
Dezembro & 303,7 & 21,1 & 32,6 & 95,8 & 79,2 & 59,6 \\
Janeiro & 276,7 & 20,8 & 30,4 & 87,2 & 83,8 & 89,5 \\
Fevereiro & $109,5^{4}$ & 20,7 & 33,2 & 125,3 & 71,0 & 166,8 \\
Março & $126,7^{5}$ & 20,2 & 32,4 & 90,5 & 72,5 & 161,0 \\
Junho & 77,9 & 13,8 & 29,0 & 80,3 & 64,9 & 208,0 \\
Julho & 0,0 & 13,4 & 30,2 & 109,6 & 56,4 & 229,5 \\
Agosto & 0,0 & 14,8 & 32,9 & 149,3 & 47,7 & 243,0 \\
Setembro & 2,7 & 19,6 & 36,4 & 160,1 & 54,5 & 144,2 \\
\hline
\end{tabular}

Dados da Fazenda Três Irmãos; ${ }^{2}$ Evaporação em Tanque Classe A; ${ }^{3}$ Umidade relativa do ar, ${ }^{4}$ Dois periodos de veranico: de 9 dias $\left(05\right.$ a 13/02) e 10 dias $\left(17\right.$ a 26/02); ${ }^{5}$ Dois periodos de veranico: de 9 dias $(28 / 02$ a $08 / 03)$ e 18 dias (12 a $29 / 03)$.

Apêndice 2. População de Rhizoctonia solani p.v. phaseoli e Fusarium solani p.v. phaseoli da Fazenda Três Irmãos, do ano agrícola de $1997^{1}$.

\begin{tabular}{ccc}
\hline Manejo & Rhizoctonia solani p.v. phaseoli & Fusarium solani p.v. phaseoli \\
\cline { 2 - 3 } & \multicolumn{2}{c}{ propágulos $\mathrm{g}^{-1}$ de solo } \\
$\mathrm{PD}^{2}$ & 88,7 & 5205 \\
$\mathrm{AP}^{3}$ & 45,0 & 2235 \\
\hline
\end{tabular}

Tados coletados da área experimental; ${ }^{2} \mathrm{PD}=$ plantio direto; ${ }^{3} \mathrm{AP}=$ aração profunda. 
Apêndice 3. Demonstrativo de custos da cultura de milho para adubação $T$, nos manejos de solo com plantio direto (PD), gradeação (GA), escarificação (ES) e aração profunda (AP).

\begin{tabular}{|c|c|c|c|c|c|c|c|c|}
\hline \multirow{2}{*}{$\frac{\text { MANEJO }}{\text { INSUMOS/SERVIÇOS }}$} & \multicolumn{2}{|c|}{ PD } & \multicolumn{2}{|c|}{ GA } & \multicolumn{2}{|c|}{ ES } & \multicolumn{2}{|c|}{ AP } \\
\hline & US\$Ma & $\%$ & US\$/na & $\%$ & US\$/na & $\%$ & US\$/ha & $\%$ \\
\hline PREPARO DO SOLO ${ }^{1}$ & 18,92 & 5,61 & 19,92 & 5,88 & 37,34 & 10,46 & 57,26 & 15,14 \\
\hline SEMEADURA & 77,97 & 23,10 & 77,97 & 23,03 & 77,97 & 21,83 & 77,97 & 20,62 \\
\hline Sementes $^{2}$ & 24,90 & 7,38 & 24,90 & 7,35 & 24,90 & 6,97 & 24,90 & 6,58 \\
\hline Tratamento de sementes ${ }^{3}$ & 6,24 & 1,85 & 6,24 & 1,84 & 6,24 & 1,75 & 6,24 & 1,65 \\
\hline Adubos $^{4}$ & 8,36 & 2,48 & 8,36 & 2,47 & 8,36 & 2,34 & 8,36 & 2,21 \\
\hline Máquinas e mão-de-obra & 38,46 & 11,40 & 38,46 & 11,36 & 38,46 & 10,77 & 38,46 & 10,17 \\
\hline ADUBAÇÃO DE & 108,87 & 32,26 & 108,87 & 32,16 & 108,87 & 30,49 & 108,87 & 28,79 \\
\hline \multicolumn{9}{|l|}{ COBERTURA } \\
\hline Adubos $^{5}$ & 94,93 & 28,13 & 94,93 & 28,04 & 94,93 & 26,59 & 94,93 & 25,10 \\
\hline Máquinas & 13,94 & 4,13 & 13,94 & 4,12 & 13,94 & 3,90 & 13,94 & 3,69 \\
\hline TRATOS CULTURAIS & 47,12 & 13,96 & 47,12 & 13,92 & 47,12 & 13,20 & 47,12 & 12,46 \\
\hline Herbicidas $^{6}$ & 17,95 & 5,32 & 17,95 & 5,30 & 17,95 & 5,03 & 17,95 & 4,75 \\
\hline Inseticidas ${ }^{7}$ & 13,24 & 3,92 & 13,24 & 3,91 & 13,24 & 3,71 & 13,24 & 3,50 \\
\hline Máquinas e mão-de-obra & 15,93 & 4,72 & 15,93 & 4,71 & 15,93 & 4,46 & 15,93 & 4,21 \\
\hline COLHEITA $^{8}$ & 65,56 & 19,42 & 65,56 & 19,36 & 65,56 & 18,36 & 65,56 & 17,34 \\
\hline ADMINISTRAÇÃO & 19,10 & 5,66 & 19,17 & 5,66 & 20,22 & 5,66 & 21,41 & 5,66 \\
\hline CUSTO TOTAL (US\$/ha) & 337,54 & 100 & 338,60 & 100 & 357,07 & 100 & 378,19 & 100 \\
\hline CUSTO TOTAL (US\$/sc) & 3,44 & - & 3,55 & - & 3,56 & - & 3,45 & - \\
\hline $\begin{array}{l}{ }^{1} \text { Uso de dessecante Glyphosate (PD), } \\
\text { aradora e } 3 \text { Hm com arado de aivecas } \\
{ }^{2} 20 \mathrm{~kg} \text { de sementes do hibrido BR } 31 \\
{ }^{3} 0,41 \text { de Thiodicarb. } \\
{ }^{4} 67 \mathrm{~kg} \text { de Uréia e } 30 \mathrm{~kg} \text { de FTE-BR } \\
5572 \mathrm{~kg} \text { de Sulfato de Amônio. } \\
{ }^{6} 41 \text { de Atrazine e } 0,51 \text { de Espalhant } \\
711 \text { de Chlorpirifos e } 0,151 \text { de Lamb } \\
{ }^{8} \text { Operações de trilha, transporte e mẑ }\end{array}$ & $\begin{array}{l}\text { ivo }(200 \mathrm{~g} \\
\text { alothrin. } \\
\text { obra. }\end{array}$ & de arado & $\mathrm{ra}(\mathrm{GA}), 3$ & $\mathrm{Hm}$ com & escarifica & dor (ES) & e $2 \mathrm{Hm} \mathrm{co}$ & m grade \\
\hline
\end{tabular}


Apêndice 4. Demonstrativo de custos da cultura de milho para adubação Eg, nos manejos de solo com plantio direto (PD), gradeação (GA), escarificação (ES) e aração profunda (AP).

\begin{tabular}{|c|c|c|c|c|c|c|c|c|}
\hline MANEJO & \multicolumn{2}{|c|}{ PD } & \multicolumn{2}{|c|}{ GA } & \multicolumn{2}{|c|}{ ES } & \multicolumn{2}{|c|}{ AP } \\
\hline INSUMOS/SERVIÇOS & US\$/ha & $\%$ & US\$ha & $\%$ & US\$/ha & $\%$ & US\$/ha & $\%$ \\
\hline PREPARO DO SOLO ${ }^{1}$ & 18,92 & 4,40 & 19,92 & 4,62 & 37,34 & 8,31 & 57,26 & 12,17 \\
\hline SEMEADURA & 165,08 & 38,40 & 165,08 & 38,30 & 165,08 & 36,73 & 165,08 & 35,08 \\
\hline Sementes ${ }^{2}$ & 24,90 & 5,79 & 24,90 & 5,78 & 24,90 & 5,54 & 24,90 & 5,29 \\
\hline Tratamento de sementes ${ }^{3}$ & 6,24 & 1,45 & 6,24 & 1,45 & 6,24 & 1,39 & 6,24 & 1,33 \\
\hline Adubos ${ }^{4}$ & 8,36 & 1,94 & 8,36 & 1,94 & 8,36 & 1,86 & 8,36 & 1,78 \\
\hline Máquinas e mão-de-obra & 125,59 & 29,21 & 125,59 & 29,13 & 125,59 & 27,94 & 125,59 & 26,69 \\
\hline $\begin{array}{l}\text { ADUBAÇÃO DE } \\
\text { COBERTURA }\end{array}$ & 108,87 & 25,32 & 108,87 & 25,27 & 108,87 & 24,22 & 108,87 & 23,14 \\
\hline Adubos $^{5}$ & 94,93 & 22,08 & 94,93 & 22,03 & 94,93 & 21,12 & 94,93 & 20,18 \\
\hline Máquinas & 13,94 & 3,24 & 13,94 & 3,24 & 13,94 & 3,10 & 13,94 & 2,96 \\
\hline TRATOS CULTURAIS & 47,12 & 10,97 & 47,12 & 10,94 & 47,12 & 10,49 & 47,12 & 10,02 \\
\hline Herbicidas $^{6}$ & 17,95 & 4,18 & 17,95 & 4,17 & 17,95 & 3,99 & 17,95 & 3,81 \\
\hline Inseticidas ${ }^{7}$ & 13,24 & 3,08 & 13,24 & 3,07 & 13,24 & 2,95 & 13,24 & 2,82 \\
\hline Máquinas e mão-de-obra & 15,93 & 3,71 & 15,93 & 3,70 & 15,93 & 3,55 & 15,93 & 3,39 \\
\hline COLHEITA $^{8}$ & 65,56 & 15,25 & 65,56 & 15,21 & 65,56 & 14,59 & 65,56 & 13,93 \\
\hline ADMINISTRAÇÃO & 24,33 & 5,66 & 29,39 & 5,66 & 30,65 & 5,66 & 26,63 & 5,66 \\
\hline CUSTO TOTAL (US\$/ha) & 429,89 & 100 & 430,95 & 100 & 449,42 & 100 & 470,53 & 100 \\
\hline CUSTO TOTAL (US\$/Sc) & 4,11 & - & 4,14 & - & 4,36 & - & 4,06 & - \\
\hline
\end{tabular}

${ }^{1}$ Uso de dessecante Glyphosate (PD), $2 \mathrm{Hm}$ com grade aradora (GA), $3 \mathrm{Hm}$ com escarificador (ES) e $2 \mathrm{Hm}$ com grade aradora e $3 \mathrm{Hm}$ com arado de aivecas (AP).

${ }^{2} 20 \mathrm{~kg}$ de sementes do híbrido BR 3123 .

${ }^{3} 0,41$ de Thiodicarb.

${ }_{5}^{4} 67 \mathrm{~kg}$ de Uréia, $415 \mathrm{~kg}$ de SPS, $92 \mathrm{~kg}$ de $\mathrm{KCl}$ e $30 \mathrm{~kg}$ de FTE-BR 12.

${ }^{5} 572 \mathrm{~kg}$ de Sulfato de Amônio.

${ }^{6} 41$ de Atrazine e 0,5 1 de Espalhante adesivo $(200 \mathrm{~g} /)$.

${ }^{7} 11$ de Chlorpirifos e 0,15 1 de Lambdacyhalothrin.

${ }^{8}$ Operações de trilha, transporte e mão-de-obra. 
Apêndice 5. Demonstrativo de custos da cultura de soja para adubação T, nos manejos de solo com plantio direto (PD), gradeação (GA), escarificação (ES) e aração profunda (AP).

\begin{tabular}{|c|c|c|c|c|c|c|c|c|}
\hline MANEJO & \multicolumn{2}{|c|}{ PD } & \multicolumn{2}{|c|}{ GA } & \multicolumn{2}{|c|}{ ES } & \multicolumn{2}{|c|}{ AP } \\
\hline INSUMOS/SERVIÇOS & US\$/ha & $\%$ & US\$/ha & $\%$ & US\$/ha & $\%$ & US\$/ha & $\%$ \\
\hline PREPARO DO SOLO' & 18,92 & 7,82 & 19,92 & 7,82 & 37,34 & 13,67 & 57,26 & 19,46 \\
\hline SEMEADURA & 65,97 & 27,26 & 65,97 & 25,91 & 65,97 & 24,15 & 65,97 & 22,42 \\
\hline Sementes ${ }^{2}$ & 24,90 & 10,29 & 24,90 & 9,78 & 24,90 & 9,11 & 24,90 & 8,46 \\
\hline Tratamento de sementes $^{3}$ & 7,82 & 3,23 & 7,82 & 3,07 & 7,82 & 2,86 & 7,82 & 2,66 \\
\hline Adubos $^{4}$ & 8,36 & 3,46 & 8,36 & 3,28 & 8,36 & 3,06 & 8,36 & 2,84 \\
\hline Máquinas e mão-de-obra & 24,90 & 10,29 & 24,90 & 9,78 & 24.90 & 9,12 & 24,90 & 8,46 \\
\hline TRATOS CULTURAIS & 68,72 & 28,39 & 79,67 & 31,28 & 79,67 & 29,17 & 79,67 & 27,08 \\
\hline Herbicidas $^{5}$ & 29,34 & 12,12 & 40,29 & 15,82 & 40,29 & 14,75 & 40,29 & 13,69 \\
\hline Inseticidas ${ }^{6}$ & 19,47 & 8,04 & 19,47 & 7,64 & 19,47 & 7,13 & 19,47 & 6,62 \\
\hline Máquinas e mão-de-obra & 19,92 & 8,23 & 19,92 & 7,82 & 19,92 & 7,29 & 19,92 & 6,77 \\
\hline COLHEITA $^{7}$ & 74,69 & 30,87 & 74,69 & 29,33 & 74,69 & 27,35 & 74,69 & 25,38 \\
\hline Administração & 13,70 & 5,66 & 14,41 & 5,66 & 15,46 & 5,66 & 16,66 & 5,66 \\
\hline CUSTO TOTAL (USS/ha) & 242,00 & 100 & 254,66 & 100 & 273,14 & 100 & 294,25 & 100 \\
\hline CUSTO TOTAL (US\$/SC) & 4,09 & - & 4,31 & - & 4,67 & - & 5,06 & - \\
\hline
\end{tabular}

T'Uso de dessecante Glyphosate (PD), $2 \mathrm{Hm}$ com grade aradora (GA), $3 \mathrm{Hm}$ com escarificador (ES) e $2 \mathrm{Hm}$ com grade aradora e $3 \mathrm{Hm}$ com arado de aivecas (AP).

${ }^{2} 60 \mathrm{~kg}$ de sementes da variedade Fl-Estrela

${ }^{3} 0,21$ de Carboxin + Thiran, 0,251 de Micronutriente e $0,2 \mathrm{~kg}$ de Inoculante

$30 \mathrm{~kg}$ de FTE-BR 12.

51,2 l de Fluasifop-p-butil. 0,04 1 de Chlorimuron-ethil e 0,5 1 de Espalhante adesivo (200g/1) (PD) e, 1,2 1 de Fluasifopp-butil, 0,04 1 de Chlorimuron-ethil +0.61 de Bentazon e 0.51 de Espalhante adesivo (200g/1) (GA, ES e AP).

${ }^{5} 0.751$ de Chlorpirifos e 1.21 de Metamidofos.

${ }^{7}$ Operações de trilha, transporte e mão-de-obra. 
Apêndice 6. Demonstrativo de custos da cultura de soja para adubação Eg, nos manejos de solo com plantio direto (PD), gradeação (GA), escarificação (ES) e aração profunda (AP).

\begin{tabular}{|c|c|c|c|c|c|c|c|c|}
\hline MANEJO & \multicolumn{2}{|c|}{ PD } & \multicolumn{2}{|c|}{ GA } & \multicolumn{2}{|c|}{ ES } & \multicolumn{2}{|c|}{ AP } \\
\hline INSUMOSISERVIÇOS & US\$Ma & $\%$ & US\$/ha & $\%$ & US\$ha & $\%$ & US\$/ha & $\%$ \\
\hline PREPARO DO SOLO ${ }^{1}$ & 18,92 & 6,34 & 19,92 & 6,41 & 37,34 & 11,34 & 57,26 & 16,34 \\
\hline SEMEADURA & $\begin{array}{c}119,0 \\
2\end{array}$ & 39,91 & $\begin{array}{c}119,0 \\
2\end{array}$ & 38,28 & $\begin{array}{c}119,0 \\
2\end{array}$ & 36,14 & $\begin{array}{c}119,0 \\
2\end{array}$ & 33,96 \\
\hline Sementes $^{2}$ & 24,90 & 8,35 & 24,90 & 8,01 & 24,90 & 7,56 & 24,90 & 7,10 \\
\hline Tratamento de sementes ${ }^{3}$ & 7,82 & 2,62 & 7,82 & 2,51 & 7,82 & 2,37 & 7,82 & 2,23 \\
\hline Adubos $^{4}$ & 8,36 & 2,80 & 8,36 & 2,69 & 8,36 & 2,54 & 8,36 & 2,39 \\
\hline Máquinas e mão-de-obra & 77,94 & 26,13 & 77,94 & 25,07 & 77,94 & 23,66 & 77,94 & 22,24 \\
\hline TRATOS CULTURAIS & 68,72 & 23,05 & 79,67 & 25,63 & 79,67 & 24,19 & 79,67 & 22,73 \\
\hline Herbicidas $^{5}$ & 29,34 & 9,84 & 40,29 & 12,96 & 40,29 & 12,23 & 40,29 & 11,50 \\
\hline Inseticidas ${ }^{6}$ & 19,47 & 6,53 & 19,47 & 6,26 & 19,47 & 5,91 & 19,47 & 5,55 \\
\hline Máquinas e mão-de-obra & 19,92 & 6,68 & 19,92 & 6,41 & 19,92 & 6,05 & 19,92 & 5,68 \\
\hline COLHEITA ${ }^{7}$ & 74,69 & 25,04 & 74,69 & 24,02 & 74,69 & 22,68 & 74,69 & 21,31 \\
\hline Administração & 16.88 & 5,66 & 17,60 & 5,66 & 18,64 & 5,66 & 19,84 & 5,66 \\
\hline CUSTO TOTAL (US\$/ha) & $\begin{array}{c}298,2 \\
2\end{array}$ & 100 & $\begin{array}{c}310,8 \\
9\end{array}$ & 100 & $\begin{array}{c}329,3 \\
7\end{array}$ & 100 & $\begin{array}{c}350,4 \\
8\end{array}$ & 100 \\
\hline CUSTO TOTAL (US\$/SC) & 4,93 & - & 5,16 & - & 5,17 & - & 5,61 & - \\
\hline
\end{tabular}

${ }^{1}$ Uso de dessecante Glyphosate (PD), $2 \mathrm{Hm}$ com grade aradora (GA), $3 \mathrm{Hm}$ com escarificador (ES) e $2 \mathrm{Hm}$ com grade aradora e $3 \mathrm{Hm}$ com arado de aivecas (AP).

${ }^{2} 60 \mathrm{~kg}$ de sementes da variedade FT-Estrela.

${ }^{3} 0,21$ de Carboxin + Thiran, 0,251 de Micronutriente e $0,2 \mathrm{~kg}$ de Inoculante.

${ }^{4} 175 \mathrm{~kg}$ de SPS, $108 \mathrm{~kg}$ de $\mathrm{KCl}$ e $30 \mathrm{~kg}$ de FTE-BR 12

${ }^{5} 1,21$ de Fluasifop-p-butil, 0,04 1 de Chlorimuron-ethil e 0,51 de Espalhante adesivo (200g/1) (PD) e, 1,21 de Fluasifopp-butil, 0,041 de Chlorimuron-ethil $+0,61$ de Bentazon e 0,51 de Espalhante adesivo $(200 \mathrm{~g} / 1)(\mathrm{GA}$, ES e AP).

${ }^{\circ} 0.751$ de Chlorpirifos e 1,21 de Metamidofos.

${ }^{7}$ Operações de trilha, transporte e mão-de-obra. 
Apêndice 7. Demonstrativo de custos da cultura de feijão para adubação $T$, nos manejos de solo com plantio direto (PD), gradeação (GA), escarificação (ES) e aração profunda (AP).

\begin{tabular}{|c|c|c|c|c|c|c|c|c|}
\hline \multirow{2}{*}{$\frac{\text { MANEJO }}{\text { INSUMOS/SERVIÇOS }}$} & \multicolumn{2}{|c|}{ PD } & \multicolumn{2}{|c|}{ GA } & \multicolumn{2}{|c|}{ ES } & \multicolumn{2}{|c|}{ AP } \\
\hline & US\$ha & $\%$ & US\$/ha & $\%$ & US\$/ha & $\%$ & US\$/ha & $\%$ \\
\hline PREPARO DO SOLO ${ }^{1}$ & 18,92 & 3,25 & 19,92 & 3,27 & 37,34 & 5,98 & 57,26 & 8,83 \\
\hline SEMEADURA & 132,37 & 22,72 & 132,37 & 21,74 & 132,37 & 21,21 & 132,37 & 20,41 \\
\hline Sementes ${ }^{2}$ & 66,80 & 11,46 & 66,80 & 10,97 & 66,80 & 10,70 & 66,80 & 10,30 \\
\hline Tratamento de sementes ${ }^{3}$ & 18,74 & 3,22 & 18,74 & 3,08 & 18,74 & 3,01 & 18,74 & 2,89 \\
\hline Adubos $^{4}$ & 8,36 & 1,44 & 8,36 & 1,37 & 8,36 & 1,34 & 8,36 & 1,29 \\
\hline Máquinas e mão-de-obra & 38,46 & 6,60 & 38,46 & 6,32 & 38,46 & 6,16 & 38,46 & 5,93 \\
\hline $\begin{array}{l}\text { ADUBAÇÃO DE } \\
\text { COBERTURA }\end{array}$ & 62,24 & 10,68 & 62,24 & 10,22 & 62,24 & 9,97 & 62,24 & 9,60 \\
\hline Adubos $^{5}$ & 55,27 & 9,48 & 55,27 & 9,08 & 55,27 & 8,85 & 55,27 & 8,52 \\
\hline Máquinas & 6,97 & 1,20 & 6,97 & 1,14 & 6,97 & 1,12 & 6,97 & 1,08 \\
\hline TRATOS CULTURAIS & 114,36 & 19,64 & 117,26 & 19,27 & 114,36 & 18,32 & 117,26 & 18,08 \\
\hline Herbicidas $^{6}$ & 21,42 & 3,68 & 24,32 & 4,0 & 21,42 & 3,43 & 24,32 & 3,75 \\
\hline Inseticidas ${ }^{7}$ & 19,40 & 3,33 & 19,40 & 3,19 & 19,40 & 3,11 & 19,40 & 2,99 \\
\hline Fungicidas $^{8}$ & 45,66 & 7,84 & 45,66 & 7,50 & 45,66 & 7,31 & 45,66 & 7,04 \\
\hline Máquinas e mão-de-obra & 27,88 & 4,79 & 27,88 & 4,58 & 27,88 & 4,47 & 27,88 & 4,30 \\
\hline IRRIGAÇÃOO & 62,24 & 10,67 & 82,99 & 13,63 & 82,99 & 13,29 & 82,99 & 12,80 \\
\hline COLHEITA $^{10}$ & 159,59 & 27,38 & 159,59 & 26,21 & 159,59 & 25,57 & 159,59 & 24,62 \\
\hline Administração & 32,98 & 5,66 & 34,46 & 5,66 & 35,34 & 5,66 & 36,71 & 5,66 \\
\hline CUSTO TOTAL (US\$/ha) & 582,70 & 100 & 608,82 & 100 & 624,21 & 100 & 648,40 & 100 \\
\hline CUSTO TOTAL (US\$/SC) & 15,75 & - & 16,10 & - & 16,00 & - & 14,97 & - \\
\hline
\end{tabular}

'Uso de dessecante Glyphosate (PD), $2 \mathrm{Hm}$ com grade aradora (GA). $3 \mathrm{Hm}$ com escarificador (ES) e $2 \mathrm{Hm}$ com grade aradora e $3 \mathrm{Hm}$ com arado de aivecas (AP).

${ }^{2} 70 \mathrm{~kg}$ de sementes da variedade Jalo.

${ }^{3} 0,14 \mathrm{~kg}$ de Captan, 0,07 kg de Penomy , 1,05 kg de Carbosulfan, 0,251 de Micronutriente.

${ }^{4} 67 \mathrm{~kg}$ de Ureia e $30 \mathrm{~kg}$ de FTE-BR 12: ${ }^{5} 333 \mathrm{~kg}$ de Sulfato de Amòno.

${ }^{6} 0,51$ de Fomesaten e 0,6 1 de Fluasifop-p-butil (PD e ES), 0,51 de Fomesafen e 0,81 de Fluasitop-p-butil (GA e AP) e 0,51 de Espalhante adesivo $(200 \mathrm{~g} / 1) ;{ }^{7} 0.231$ de Fenpropathrin e 11 de Metamidofos: " 31 de Chlorothalonil + Tiofanato metílico e $1,5 \mathrm{~kg}$ de Mancozeb + 0,8 de Oxicloreto $\mathrm{Cu} .{ }^{9} 13,5 \mathrm{~mm}$ (PD) e $18 \mathrm{~mm}$ (GA, ES e AP) a cada 5 dias: ${ }^{10}$ Operações de trilla. transporte e mào-de-obra 
Apêndice 8. Demonstrativo de custos da cultura de feijão para adubação Eg, nos manejos de solo com plantio direto (PD), gradeação (GA), escarificação (ES) e aração profunda (AP).

\begin{tabular}{|c|c|c|c|c|c|c|c|c|}
\hline \multirow{2}{*}{$\frac{\text { MANEJO }}{\text { INSUMOSISERVIÇOS }}$} & \multicolumn{2}{|c|}{ PD } & \multicolumn{2}{|c|}{ GA } & \multicolumn{2}{|c|}{ ES } & \multicolumn{2}{|c|}{ AP } \\
\hline & US\$Ma & $\%$ & US\$ha & $\%$ & US\$/ha & $\%$ & US\$/ha & $\%$ \\
\hline PREPARO DO SOLO ${ }^{1}$ & 18,92 & 3,05 & 19,92 & 3,08 & 37,34 & 5,64 & 57,26 & 8,34 \\
\hline SEMEADURA & 168,18 & 27,10 & 168,18 & 26,0 & 168,18 & 25,40 & 168,18 & 24,50 \\
\hline Sementes $^{2}$ & 66,80 & 10,76 & 66,80 & 10,33 & 66,80 & 10,09 & 66,80 & 9,73 \\
\hline Tratamento de sementes $^{3}$ & 18,74 & 3,02 & 18,74 & 2,90 & 18,74 & 2,83 & 18,74 & 2,73 \\
\hline Adubos $^{4}$ & 8,36 & 1,35 & 8,36 & 1,29 & 8,36 & 1,26 & 8,36 & 1,22 \\
\hline Máquinas e mão-de-obra & 74,27 & 11,97 & 74,27 & 11,48 & 74,27 & 11,22 & 74.27 & 10,82 \\
\hline $\begin{array}{l}\text { ADUBAÇÃO DE } \\
\text { COBERTURA }\end{array}$ & 62,24 & 10,03 & 62,24 & 9,63 & 62,24 & 9,40 & 62,24 & 9,07 \\
\hline Adubos $^{5}$ & 55,27 & 8,91 & 55,27 & 8,55 & 55,27 & 8,35 & 55,27 & 8,05 \\
\hline Máquinas & 6,97 & 1,12 & 6,97 & 1,08 & 6,97 & 1,05 & 6,97 & 1,02 \\
\hline TRATOS CULTURAIS & 114,36 & 18,43 & 117,26 & 18,13 & 114,36 & 17,27 & 117,26 & 17,09 \\
\hline Herbicidas $^{6}$ & 21,42 & 3,45 & 24,32 & 3,76 & 21,42 & 3,23 & 24,32 & 3,54 \\
\hline Inseticidas ${ }^{7}$ & 19,40 & 3,13 & 19,40 & 3,00 & 19,40 & 2,93 & 19,40 & 2,83 \\
\hline Fungicidas $^{8}$ & 45,66 & 7,36 & 45,66 & 7,06 & 45,66 & 6,90 & 45,66 & 6,65 \\
\hline Máquinas e mão-de-obra & 27,88 & 4,49 & 27,88 & 4,31 & 27,88 & 4,21 & 27,88 & 4,07 \\
\hline IRRIGAÇÃO $^{9}$ & 62,24 & 10,02 & 82,99 & 12,83 & 82,99 & 12,53 & 82,99 & 12,09 \\
\hline COLHEITA $^{10}$ & 159,59 & 25,71 & 159,59 & 24,67 & 159,59 & 24,10 & 159,59 & 23,25 \\
\hline Administração & 35,13 & 5,66 & 36,61 & 5,66 & 37,49 & 5,66 & 38,85 & 5,66 \\
\hline CUSTO TOTAL (US\$/ha) & 620,65 & 100 & 646,78 & 100 & 662,17 & 100 & 686,36 & 100 \\
\hline CUSTO TOTAL (US\$/SC) & 14,50 & - & 15,47 & - & 15,73 & - & 14,09 & - \\
\hline
\end{tabular}

'Uso de dessecante Glyphosate (PD), $2 \mathrm{Hm}$ com grade aradora (GA), $3 \mathrm{Hm}$ com escarificador (LS) e $2 \mathrm{Hm}$ com grade aradora e $3 \mathrm{Hm}$ com arado de aivecas (AP).

${ }^{2} 70 \mathrm{~kg}$ de sementes da variedade Jalo.

${ }^{3} 0,14 \mathrm{~kg}$ de Captan, 0,07 kg de Benomyl, 1,05 kg de Carbosulfan, 0,251 de Micronutriente.

${ }^{4} 67 \mathrm{~kg}$ de Ureia, $115 \mathrm{~kg}$ de SPS. $75 \mathrm{~kg}$ de $\mathrm{KCl}$ e $30 \mathrm{~kg}$ de FTE-BR 12: ${ }^{5} 333 \mathrm{~kg}$ de Sulfato de Amônio.

${ }^{\circ} 0,51$ de Fomesafen e 0,61 de Fluasifop-p-butil (PD e ES) 0,51 de Fomesaten e 0,81 de Fluasifop-p-butil (GA e AP) e 0.51 de Espalhante adesivo $(200 \mathrm{~g} / \mathrm{l})$

70,231 de Fenpropathrin e 11 de Metamidofos.

831 de Chlorothalonil + Tiofanato metílico e $1,5 \mathrm{~kg}$ de Mancozeb $+0,8$ de Oxicloreto $\mathrm{Cu}$

${ }^{\circ} 13,5 \mathrm{~mm}$ (PD) e $18 \mathrm{~mm}$ (GA. ES e AP) a cada 5 dias; ${ }^{10}$ Operações de trilha, transporte e mão-de-obra. 